\title{
Caracterização Limnológica e Avaliação de Efeitos Ambientais causados por Efluentes de Mina de Urânio sobre populações microbianas planctônicas da Represa das Antas, Caldas (M.G.)
}

\section{Leilane Barbosa Ronqui}

Dissertação apresentada ao Programa de Pós-Graduação Interunidades em Biotecnologia USP/Instituto Butantan/IPT

Para obtenção do Título de Mestre em Biotecnologia. 


\section{Caracterização Limnológica e Avaliação de Efeitos Ambientais causados por Efluentes de Mina de Urânio sobre populações microbianas planctônicas da Represa das Antas, Caldas (M.G.)}

\section{Leilane Barbosa Ronqui}

Dissertação apresentada ao Programa de Pós-Graduação Interunidades em Biotecnologia USP/Instituto Butantan/IPT, para obtenção do Título de Mestre em Biotecnologia.

Área de concentração: Biotecnologia Orientadora: Dra. Heliana de Azevedo Gomes 
DADOS DE CATALOGAÇÃO NA PUBLICAÇÃO (CIP)

Serviço de Biblioteca e Informação Biomédica do

Instituto de Ciências Biomédicas da Universidade de São Paulo

(c) reprodução total

Ronqui, Leilane Barbosa.

Caracterização limnológica e avaliação de efeitos ambientais causados por efluente de mina de urânio sobre populações microbianas planctônicas da Represa das Antas, Caldas (M.G.) / Leilane Barbosa Ronqui. -- São Paulo, 2008.

Orientador: Dra. Heliana de Azevedo Gomes.

Dissertação (Mestrado) - Universidade de São Paulo. Instituto de Ciências Biomédicas. Programa de Pós-Graduação Interunidades em Biotecnologia USP/IPT/Instituto Butantan. Área de concentração: Biotecnologia. Linha de pesquisa: Ecologia de microorganismos aquáticos e avaliação de impacto ambiental.

Versão do título para o inglês: Limnological characterization and evaluation of environmental effects caused by uranium mine effluents on planktonic microbial communitties in the Antas reservoir, Caldas (M.G.).

Descritores: 1. Protozooplâncton 2. Peridinium sp. 3.

Bacterioplâncton 4. Mina de urânio 5. Efluentes ácidos de mina 6 . Represa das Antas I. Gomes, Heliana de Azevedo II. Universidade de São Paulo. Instituto de Ciências Biomédicas. Programa de PósGraduação em Biotecnologia III. Título. 
Candidato(a): $\quad$ Leilane Barbosa Ronqui.

Título da Dissertação: Caracterização limnológica e avaliação de efeitos ambientais causados por efluente de mina de urânio sobre populações microbianas planctônicas da Represa das Antas, Caldas (M.G.)

Orientador(a): $\quad$ Dra. Heliana de Azevedo Gomes.

A Comissão Julgadora dos trabalhos de Defesa da Dissertação de Mestrado, em sessão pública realizada a ./................................,

\section{( ) Aprovado(a) $\quad$ ( ) Reprovado(a)}

Examinador(a): Assinatura:

Nome:

Instituição:

Examinador(a): Assinatura:

Nome:

Instituição:

Presidente: Assinatura:

Nome:

Instituição: 


\section{DEDICATÓRIA}

Aos meus Pais, porque eles representaram tudo; de que realmente necessitei para que este trabalho se realizasse...

Obrigada! 


\section{AGRADECIMENTOS}

- A Dra. Heliana de Azevedo Gomes pelo empenho na orientação desta dissertação e na minha formação profissional, e especialmente pela confiança depositada em meus esforços.

- A Profa. Dra. Mirna Helena Regali Seleghim pela paciência e atenção me ensinando a técnica de identificação das comunidades protozooplactônicas e dos fitoflagelados, além do auxílio nos cálculos de biovolume e biomassa, por ler e me orientar nas questões relativas ao trabalho que ainda estavam necessitando de melhor interpretação e discussão.

- Agradeço a PhD. Suzelei Rodgher pela grande ajuda prestada na conclusão deste trabalho.

- Aos técnicos, Cláudio Vitor Roque e Armando Bruschi do Laboratório de Radioecologia da CNEN, por terem me auxiliado nas análises laboratoriais e na realização das coletas, sendo de suma importância para os resultados contidos neste estudo.

- A Eva Mariano por me ajudar lavando e autoclavando todas as vidrarias utilizadas na pesquisa.

- A todos os funcionários da CNEN que participaram deste trabalho pela colaboração e ajuda.

- Ao Msc. José Flávio Macacini pelo auxílio na análise estatística de Correlação de Pearson.

- Ao Dr. Marcos Roberto Lopes do Nascimento pela realização das análises químicas e a todos os técnicos de seu laboratório.

- Aos Profs. Drs. Carlos Tadeu dos Santos Dias e Gerson Barreto Mourão pelo auxílio na análise estatística ANOVA.

- Aos meus colegas de laboratório Michelle Burato de Campos e Leonardo Ogeda Tarifa pela ajuda nas coletas e nas análises laboratoriais.

- Agradeço ao Dr. Wilson Cervi da Costa pelas referências bibliográficas cedidas e os conhecimentos sobre química prestados.

- Agradeço ao meu namorado Breno Guinart Marques pela paciência, apoio, carinho e compreensão nos inúmeros momentos difíceis.

- Agradeço aos meus pais, acima de tudo, por tudo, por estarem sempre presentes em todos os momentos de dificuldade, nervosismo e ansiedade, medo, derrota, me confortando e me apoiando integralmente. 
- A CNEN - Comissão Nacional de Energia Nuclear pela infra-estrutura oferecida para este trabalho.

- Ao Conselho Nacional de Apoio a Pesquisa Científica - CNPq, pelos recursos financeiros concedidos para a realização do trabalho.

- Ao Departamento de Ecologia e Biologia Evolutiva do Laboratório de Microbiologia de Microorganismos Aquáticos da Universidade Federal de São Carlos - UFSCAR. 
"Se alguma ocorrência desagradável lhe impôs aborrecimentos, passe por ela e siga em frente, em sua própria tarefa, à maneira de quem não precisa parar em viagem por haver encontrado uma Pedra."

Xico Chavier 


\title{
RESUMO
}

\begin{abstract}
RONQUI, L. B. Caracterização Limnológica e Avaliação dos efeitos ambientais causados por Efluentes de Mina de Urânio sobre populações microbianas planctônicas da Represa das Antas, Caldas (M.G.). 2008. 136 f. Dissertação (Mestrado em Biotecnologia) - Instituto de Ciências Biomédicas, Universidade de São Paulo, São Paulo, 2008.
\end{abstract}

A Represa das Antas (Caldas, MG) é um reservatório artificial raso que faz parte da Bacia Hidrográfica do Ribeirão das Antas. Além do fornecimento de água para a Unidade de Tratamento de Minério das Indústrias Nucleares do Brasil, este corpo aquático recebe os efluentes ácidos tratados procedentes das drenagens ácidas de minério de urânio procedente da Mina de Urânio Osamu Utsumi. O objetivo geral deste estudo foi realizar a caracterização limnológica da Represa das Antas, baseando-se na avaliação da comunidade de protozários ciliados, do dinoflagelado Peridinium sp., do bacterioplâncton, do fitoplâncton e de variáveis físicas e químicas, para a avaliação de efeitos ambientais causados por efluentes de Mina de Urânio sobre populações microbianas planctônicas. Coletas de amostras de água procedentes da Represa das Antas na Cabeceira (ponto localizado a montante da represa), no local de lançamento dos efluentes liberados pela UTM-INB (P41) e a jusante desse (P14Superficie e P14Fundo), foram realizadas durante os meses de janeiro/06, abril/06, julho/06, outubro/06 e fevereiro/07. Além da análise das variáveis físicas, químicas e bióticas das amostras de água, foram aplicados o Índice de Estado Trófico, o Índice de Saprobidade e o Índice de Diversidade. De acordo com as variáveis físicas e químicas, a represa foi caracterizada como um corpo aquático com valores de $\mathrm{pH}$ levemente ácidos, elevados valores de condutividade elétrica, dureza e concentrações de fluoreto, manganês, zinco e sulfato. A Represa das Antas foi classificada como oligotrófica e beta-mesosapróbica. O ponto P41 apresentou os menores valores de densidade e biomassa dos protozoários ciliados e do dinoflagelado Peridinium sp. ao longo de todo o período avaliado. Os resultados mostraram baixa diversidade de protozoários ciliados ao longo de todos os pontos e períodos de coleta amostrados. Foi verificada a dominância de organismos planctônicos mixotróficos (ciliado Strombidium sp. e o dinoflagelado Peridinium sp.). Parâmetros químicos indicaram falhas no tratamento de efluentes desta instalação nuclear indicando que são lançados no ponto P41 efluentes fora dos limites estabelecidos pela legislação vigente para água de Classe II. Tais resultados concordaram com as análises biológicas, uma vez que no ponto P41 foram verificados os menores valores de biomassa e densidade de protozoários ciliados e Peridinium sp., indicando possíveis efeitos ambientais do lançamento de efluentes de mineração sobre esse ecossistema.

Palavras-chave: Protozooplâncton; Bacterioplâncton; Represa das Antas; Mina de urânio; Efluentes ácidos. 


\begin{abstract}
RONQUI, L. B. Limnological characterization and evaluation of environmental effects caused by uranium mine effluents on planktonic microbial communitties in the Antas reservoir, Caldas (M.G.). 2008. $136 \mathrm{f}$. Master Thesis (Biotechnology) - Instituto de Ciências Biomédicas, Universidade de São Paulo, São Paulo, 2008.
\end{abstract}

The Antas Dam is an artificial water reservoir in the Antas River Hydrographic Basin. In addition to providing water for the ore treatment unit of the Brazilian Nuclear Industries, UTM-INB (Caldas, MG), this water body receives the treated acidic runoff from the acid drainage of low-content uranium ore in the Osamu Utsumi Uranium Mine located near the reservoir. In this study, a limnology characterization of the reservoir seeking to evaluate the possible environmental effects caused by the effluents related to the UTM-INB was done, in order to aid in the decision-making process for the recovery and management of subtropical water bodies which suffer anthropogenic interference from uranium mining and processing. For a year, quarterly sampling campaigns were carried out in the Antas Reservoir in order to analyze physical, chemical, and biotic variables (cilliated protozoans, Peridinium sp. dinoflagellate, bacterioplankton, chlorophyll, and phytoplanktonic biomass) variables. Due to physical and chemical characteristics of the reservoir, it is considered to be a water body with slightly acidic $\mathrm{pH}$; an oligotrophic and beta-mesosaprobic environment; has a high level of hardness and electrical conductivity; has high concentration levels of fluoride, manganese, zinc, and sulfate. In general, sampling point P41 (the area into which the treated effluents from UTB-INB are discharged) had the lowest values for density and biomass of cilliated protozoans and the Peridinium sp. dinoflagellate. The results showed that the biodiversity of cilliated protozoans is low throughout the evaluation period, predominantly regarding mixotrophic organisms (cilliated Strombidium sp. and Peridinium sp. dinoflagellate). Chemical parameters indicate failures in the nuclear facility effluent treatment plant, showing that effluents outside of standard limits established by current legislation for Class II water are being discharged at point P41. These results agree with biological analyses, since point P41 has the lowest biomass and density values for ciliated protozoans and Peridinium sp. organisms, indicating possible environmental effects on the ecosystem due to effluent discharge by this mining company.

Key words: Protozooplankton; Bacterioplankton; Antas Reservoir; Uranium mine; Acid effluents. 


\section{LISTA DE ILUSTRAÇÕES}

Figura 1. Localização dos pontos de amostragem na Represa das Antas e esquema mostrando as principais instalações da UTM-INB

Figura 2. Valor percentual médio de biomassa dos tipos nutricionais dos protozoários ciliados em amostras de água da Represa das Antas. .58

Figura 3. Valor percentual médio de densidade dos tipos nutricionais dos protozoários ciliados em amostras de água da Represa das Antas. .58

Figura $4(\mathrm{a} / \mathrm{b})$. Densidade dos protozoários ciliados, do dinoflagelado Peridinium sp. e do bacterioplâncton em diferentes pontos de amostragem na Represa das Antas, ao longo do período avaliado

Figura 4(c/d). Densidade dos protozoários ciliados, do dinoflagelado Peridinium sp. e do bacterioplâncton em diferentes pontos de amostragem na Represa das Antas, ao longo do período avaliado

Figura $5(\mathrm{a} / \mathrm{b})$. Biomassa dos protozoários ciliados, do dinoflagelado Peridinium sp. e do fitoplâncton em diferentes pontos de amostragem na Represa das Antas, ao longo do período avaliado.

Figura 5(c/d). Biomassa dos protozoários ciliados, do dinoflagelado Peridinium sp. e do fitoplâncton em diferentes pontos de amostragem na Represa das Antas, ao longo do período avaliado.

Figura 6. Valores de Índice de Diversidade (Diver) em amostras de água coletadas em diferentes pontos de amostragem na Represa das Antas. 


\section{LISTA DE TABELAS}

Tabela 1. Dados Hidrológicos e Morfométricos da Represa das Antas, Caldas - MG. .33

Tabela 2. Parâmetros Meteorológicos na região da Represa das Antas

Tabela 3. Valores de temperatura, de $\mathrm{pH}$, de oxigênio dissolvido, de condutividade elétrica, de sólidos em suspensão e de transparência em amostras de água da Represa das Antas, coletadas em diferentes pontos de amostragem.

Tabela 4. Valores de concentração de fósforo, de dureza, de fluoreto, de manganês, de zinco, de sulfato, de urânio e de tório em amostras de água na Represa das Antas, coletadas em diferentes pontos de amostragem

Tabela 5. Valores médios de Clorofila $a, b, c$ e de Feofitina em $\mu g . L^{-1}$ em amostras de água da Represa das Antas. .54

Tabela 6. Índice de Estado Trófico na Represa das Antas 55

Tabela 7a). Percentagem dos tipos nutricionais de protozoários ciliados e do dinoflagelado Peridinium sp. em amostras de água da Represa das Antas: a) Porcentagem calculada baseando-se nos valores de biomassa obtidos para os protozoários ciliados e o dinoflagelado Peridinium sp. em amostras de água da Represa das Antas.

Tabela 7b). Percentagem dos tipos nutricionais de protozoários ciliados e do dinoflagelado Peridinium sp. em amostras de água da Represa das Antas: b) Porcentagem calculada baseando-se nos valores de densidade obtidos para os protozoários ciliados e o dinoflagelado Peridinium sp. em amostras de água da Represa das Antas.

Tabela 8. Valores médios de biomassa e de densidade para as Classes dos protozoários ciliados e do dinoflagelado Peridinium sp., em amostras de água da Represa das Antas, ao longo do período avaliado. 
Tabela 9. Índice de saprobidade obtido em amostras de água da Represa das Antas 67

Tabela 10. Valores de Biomassa e Índice de Diversidade dos gêneros de protozoários ciliados obtido em amostras de água da Represa das

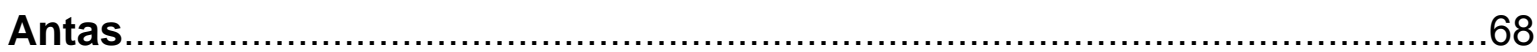




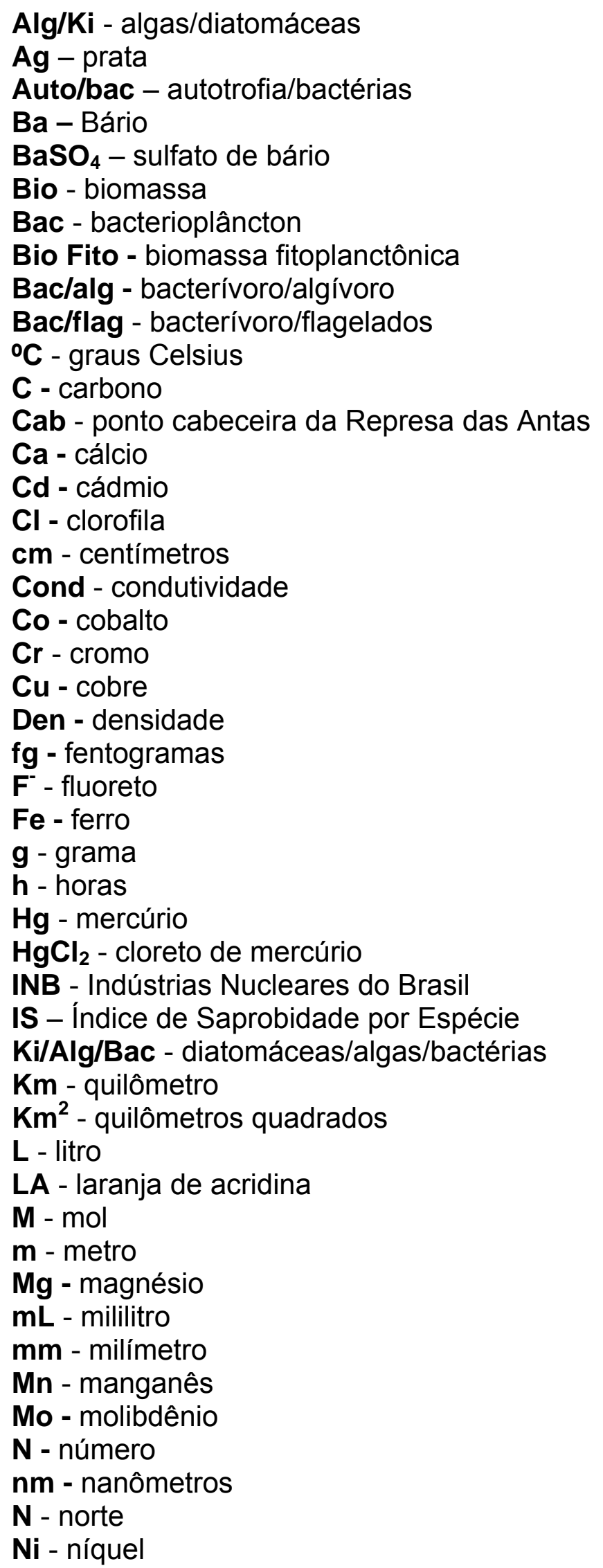


O - omnívoro

OD - oxigênio dissolvido

$\mathrm{O}_{2}$ - oxigênio

P41 - ponto 41 da Represa das Antas

P14S - ponto 14 superfície da Represa das Antas

P14F - ponto 14 fundo da Represa das Antas

pg - picogramas

$\mathrm{PO}_{4}$ - Fosfato inorgânico

$P$ total - fósforo total

$\mathbf{P b}$ - chumbo

Prot -protozooplâncton

Peri -dinoflagelado Peridinium sp.

$\mathbf{R}$ - predador

${ }^{226} \mathrm{Ra}$ - rádio

s - segundo

S - sul

Si - sílica

$\mathrm{SO}_{4}{ }^{-2}$ - sulfato

Sn - estanho

SS - sólidos em suspensão

$\mathbf{T}$ - temperatura

$\mathbf{T}^{\circ} \mathbf{C}$ - temperatura em graus Celsius

Th - tório

U - urânio

${ }^{238} \mathrm{U}$ - urânio

UTM - Unidade de Tratamento de Minério

$\boldsymbol{\mu g}$ - microgramas

$\mu \mathrm{L}$ - microlitro

$\mu \mathrm{m}$ - micrômetro

$\boldsymbol{\mu S}$ - microSiemens

Zn - zinco

'W - oeste 


\section{LISTA DE FÓRMULAS}

- Tempo de sedimentação T=3 x H

Equação (1)

- Biomassa úmida total $\left(\mu \mathrm{g} \mathrm{C} . \mathrm{I}^{-1}\right) \quad B=D \times b$

Equação (2)

- Diversidade de Shannon-Weaver $\mathrm{H}=-\Sigma(\mathrm{ni} / \mathrm{N}) \log (\mathrm{ni} / \mathrm{N})$ ou $-\Sigma \mathrm{Pi} \log \mathrm{Pi}$ Equação (3)

- Índice de Saprobidade SIPB $=\underline{\Sigma(\mathrm{N} \times \mathrm{SI})} / \Sigma \mathrm{N}$

Equação (4)

- IET $($ TranS $)=10 \times\{6-\{(0,64+\ln$ TranS $) / \ln 2]\}$

Equação (5)

- IET $(\mathrm{Cl} a)=10 \times\{6-[(2,04+\ln$ TranS $) / \ln 2]\}$

Equação (6)

$-\mathrm{Cl} a=\mathrm{A} \times \mathrm{K} \times\left(665_{0}-665_{\mathrm{a}}\right) \times v / \mathrm{V}_{\mathrm{f}} \times I$

Equação (8)

$-\mathrm{Feo}=\mathrm{A} \times \mathrm{K} \times\left(\mathrm{R}\left[665_{\mathrm{a}}\right]-665_{0}\right) \times v / \mathrm{V}_{\mathrm{f}} \times I$

Equação (9)

- Cl $b=5,43 \mathrm{E}_{664}-21,03 \mathrm{E}_{647}-2,66 \mathrm{E}_{630}$

Equação (10)

- $\mathrm{Cl} c=-1,67 \mathrm{E}_{664}-7,60 \mathrm{E}_{647}-24,52 \mathrm{E}_{630}$

Equação (11) 


\section{SUMÁRIO}

1 INTRODUÇÃO GERAL E REVISÃO DE LITERATURA................................ 17

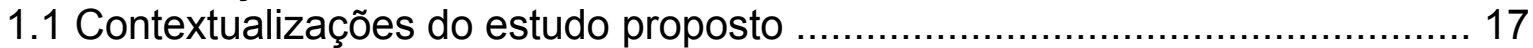

1.2 Considerações gerais sobre ecologia de reservatórios ............................... 20

1.3 Protozooplâncton e relações com outras populações microbianas planctônicas

1.4 Justificativa

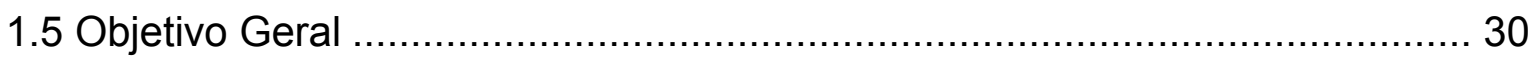

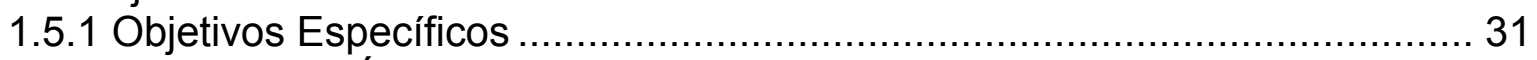

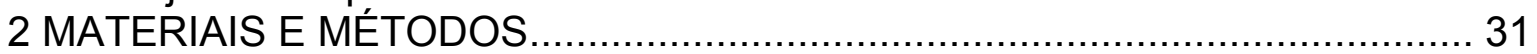

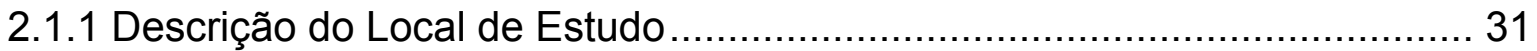

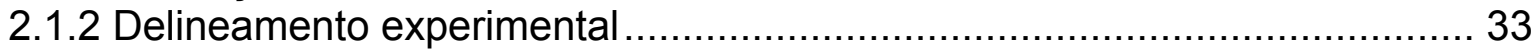

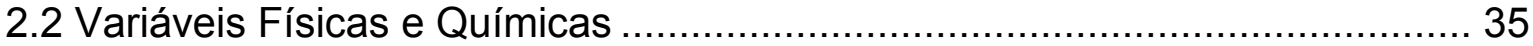

2.2.1 Parâmetros Meteorológicos............................................................. 35

2.2.2 Temperatura, $\mathrm{pH}$, condutividade, oxigênio dissolvido, transparência da água

e sólidos em suspensão..................................................................... 35

2.2.3 Dureza, Fósforo Total, Fluoreto, Manganês, Zinco, Sulfato, Urânio e Tório 36

2.3 Parâmetros Biológicos ...................................................................... 37

2.3.1 Coleta e preparo de amostras para a quantificação e identificação de protozoários ciliados e do dinoflagedo Peridinium sp..................................... 37

2.3.1.1 Identificação dos Protozoários Ciliados e Estimativa da Densidade, do

Biovolume e da Biomassa ......................................................................... 38

2.3.1.2 Estimativa de Densidade, Biovolume e Biomassa do dinoflagelado

Peridinium sp.................................................................................... 39

2.3.2 Coleta, preparo de amostras e estimativa da densidade bacteriana ........... 40

2.3.5 Tipos Nutricionais dos Protozoários Ciliados e do dinoflagelado Peridinium

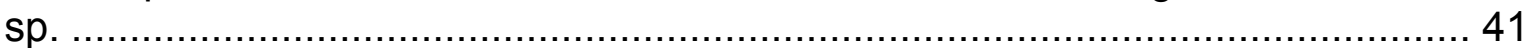

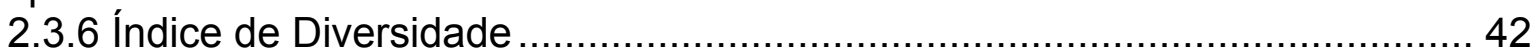

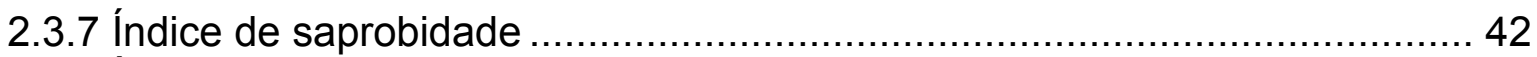

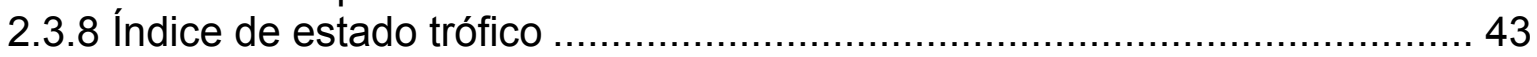

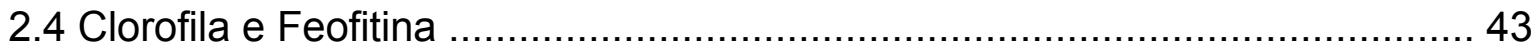

2.4.1 Estimativa de Biomassa Fitoplanctônica .............................................. 44

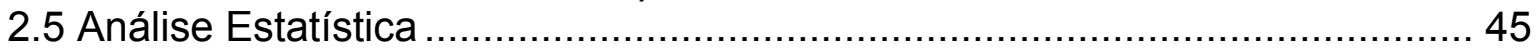

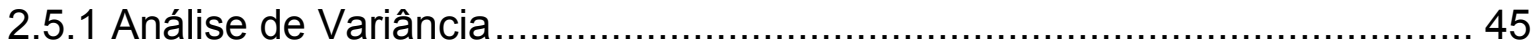

2.5.2 Análise de Correlação de Pearson ...................................................... 45

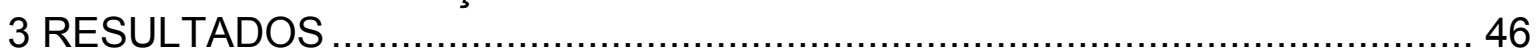

3.1 Parâmetros Meteorológicos.................................................................. 46

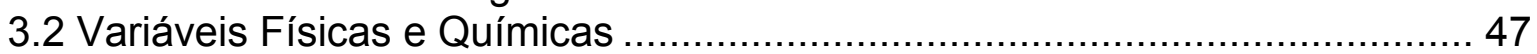

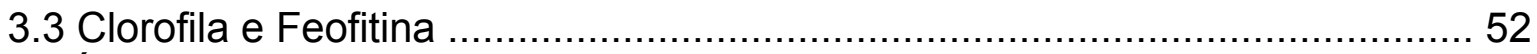

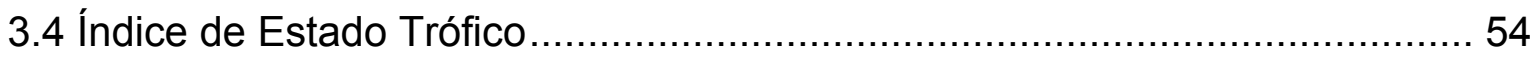

3.5 Variáveis Biológicas ............................................................................. 55

3.5.1 Tipos nutricionais, classes e gêneros dos protozoários ciliados e do dinoflagelado Peridinium sp. ................................................................. 55

3.5.2 Variação Sazonal e Espacial dos protozoários ciliados, do dinoflagelado

Peridinium sp., do bacterioplâncton e da biomassa fitoplanctônica na Represa das

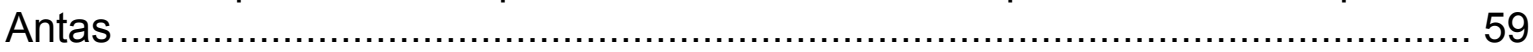

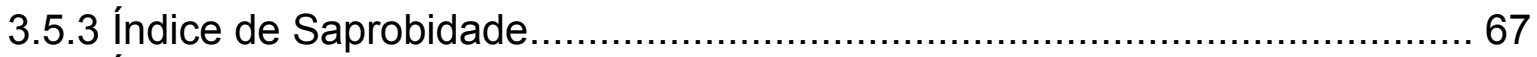

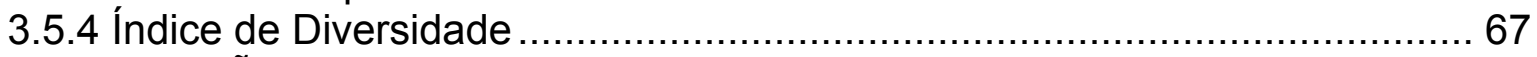

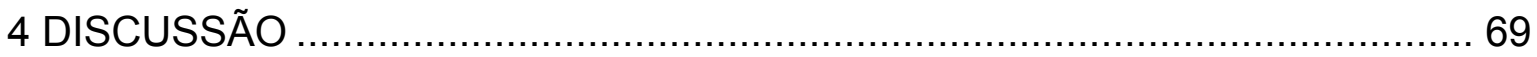




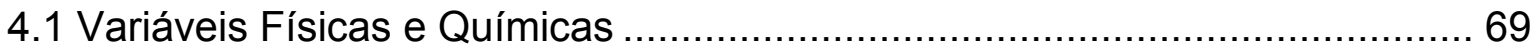

4.2 Variáveis Biológicas ........................................................................ 77

4.2.1 Relações tróficas dos tipos nutricionais, Classe e Gêneros dos protozoários ciliados, do dinoflagelado Peridinium sp. e outras populações microbianas planctônicas

4.2.2 Variação Sazonal e Espacial dos protozoários ciliados, do dinoflagelado Peridinium sp., do bacterioplâncton e da biomassa fitoplanctônica na Represa das

Antas 87

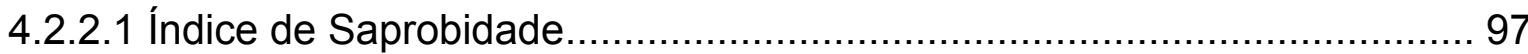

4.2.2.2 Índice de Diversidade ............................................................... 98

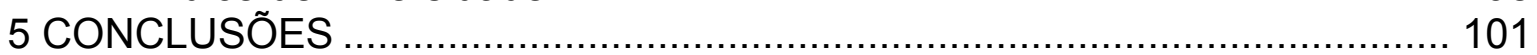

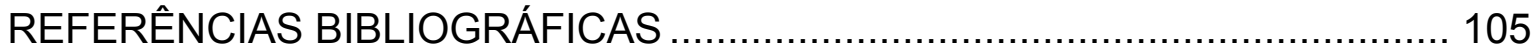

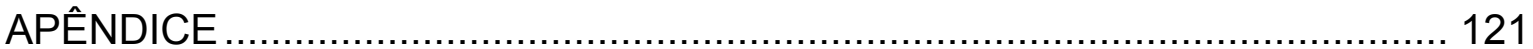

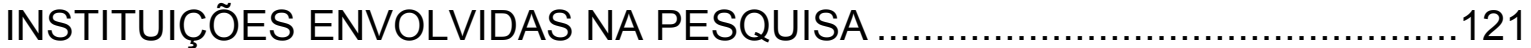

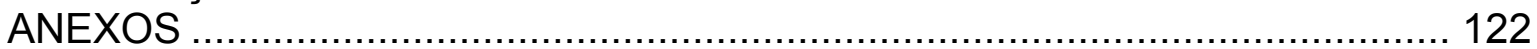

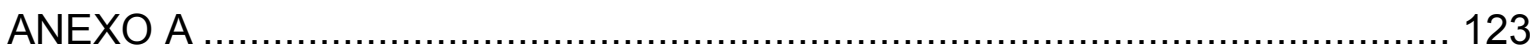

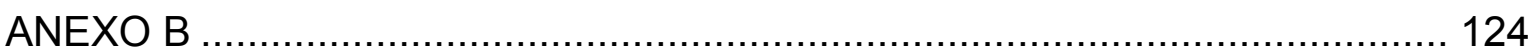

Unidade de Tratamento de Minérios - Indústrias Nucleares do Brasil ............... 124

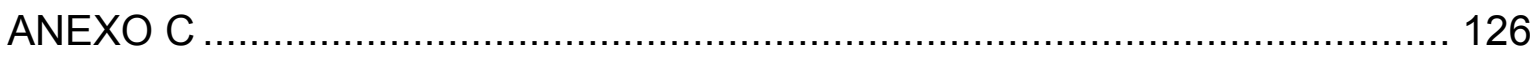

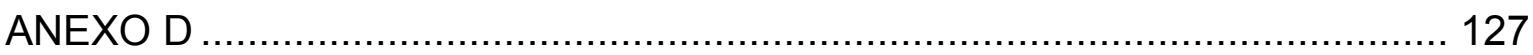




\section{INTRODUÇÃO GERAL E REVISÃO DE LITERATURA}

\subsection{Contextualizações do estudo proposto}

A principal fonte de água doce no planeta provém do escoamento de águas de superfície. O escoamento global anual é de $44.500 \mathrm{Km}^{2}$ por ano. A distribuição dessas águas superficiais é extremamente desigual na Terra; mais da metade do escoamento ocorre na Ásia e América do Sul. Portanto, o continente sulamericano e o Brasil apresentam uma das maiores reservas de águas interiores do planeta. Os vastos recursos hídricos do Brasil têm grande significado ecológico, econômico e social, porém a contínua interferência de atividades humanas nestes sistemas aquáticos produz impactos com consequências para a qualidade da água, a biota aquática e o funcionamento de lagos, rios e represas. Dentre estas atividades impactantes estão: o desmatamento, o despejo de material residual, a construção de reservatórios e a mineração (REBOUÇAS; BRAGA; TUNDISI, 2006).

A mineração tem se tornado importante para a economia brasileira sendo que a produção industrial extrativista representou aproximadamente US\$ 9,1 bilhões no ano de 2007 (IBRAM, 2008). Um dos problemas ambientais decorrentes desta atividade é a drenagem ácida de mina que pode comprometer a qualidade dos recursos hídricos da região de sua ocorrência (REBOUÇAS; BRAGA; TUNDISI, 2006). A região de Poços de Caldas, Minas Gerais e a região carbonífera ao sul do País (Estado de Santa Catarina), contribuem significativamente para este problema (SOUZA, 1995).

Para que ocorra a drenagem ácida de mina é fundamental a presença de sulfeto metálico associado ao minério. O mineral sulfetado sofre processo de oxidação natural e, em contato com a água da chuva ou umidade produz ácido sulfúrico que diluí-se na água e solubiliza metais presentes na rocha. A drenagem ácida de mina é caracterizada por constituir-se em efluente apresentando, elevada acidez e elevadas concentrações de metais solubilizados, como o alumínio, o cobre, o ferro, o manganês, o zinco, o urânio e outros (LYEW et al. 2001). Os metais são transportados através da drenagem dessa água e quando alcançam os corpos de água ou lençóis freáticos, acabam comprometendo a qualidade dos 
mesmos. A composição do efluente dependerá da composição da rocha, bem como do processo produtivo de exploração mineral (CAMPOS, 2006).

O Planalto de Poços de Caldas é uma região caracterizada por inúmeras anomalias de alta radioatividade natural associadas com rochas vulcânicas e depósitos de minerais de urânio. Os depósitos de urânio ocorrem associados ao sulfeto de ferro $\left(\mathrm{FeS}_{2}\right)$ propiciando as condições para a ocorrência de drenagem ácida de mina (NORDSTROM; SMELLE; WOLF, 1990).

Nesta região do Planalto de Poços de Caldas está localizada a Mina de Urânio Osamu Utsumi que consiste na primeira mina de extração de minério de urânio do Brasil, localizada nas dependências da Unidade de Tratamento de MinériosIndústrias Nucleares do Brasil (UTM - INB) (Anexo B). Na UTM - INB encontra-se uma mina a céu aberto (Mina de Urânio Osamu Utsumi) e suas áreas de deposição de rejeitos de mineracao, instalações de tratamento físico de minério, usina de tratamento químico para extração de urânio e bacia de rejeitos, além das instalações de utilidades e administrativas. Após funcionamento descontínuo desde 1977, em 1995 houve a paralisação definitiva das atividades de lavra e de tratamento químico de minério de urânio (MARQUES, 2006).

As águas de surgência e de drenagens ácidas provenientes das infiltrações e percolação pluvial do interior da UTM-INB convergem para a Cava da Mina, de onde são bombeadas para a estação de tratamento de efluentes (NASCIMENTO, 1998). Após receber tratamento com hidróxido de cálcio para precipitação de metais e radionuclídeos, esse efluente é lançado na Represa das Antas. De acordo com Cipriani (2002), em 2001, o volume de água ácida tratado na UTMINB e lançado na Represa das Antas foi de $1.414 .851 \mathrm{~m}^{3}$.

Atualmente, os trâmites legais para a remediação do local e descomissionamento da instalação estão em andamento, devendo o empreendedor cumprir as exigências estabelecidas pela Comissão Nacional de Energia Nuclear (CNEN) e o Instituto Brasileiro de Meio Ambiente (IBAMA), através do Plano de Recuperação de Áreas Degradadas a ser apresentado pela UTM-INB, de acordo com termo de referência detalhado, redigido especificamente para este caso (IBAMA, ofício nº 099/2004 - DILIQ).

O Brasil ainda não detêm a tecnologia nem a experiência prática sistematizadas para a remediação e o descomissionamento de minas e usinas de 
urânio, mas seus órgãos reguladores, nuclear e ambiental, têm a responsabilidade legal de fazer a análise de segurança para determinar as conseqüências, a curto e longo prazo, para humanos e o meio ambiente, associadas às ações de descomissionamento e do fechamento definitivo da instalação propostas pelo empreendedor.

A Represa das Antas localiza-se na região da cabeceira da Sub-Bacia Hidrográfica do Ribeirão das Antas que constitui a maior e principal rede hidrográfica do Planalto de Poços de Caldas espalhando-se por toda a região centro-ocidental, cobrindo uma área de $422,96 \mathrm{~km}^{2}$. Os rios que compõe a SubBacia Hidrográfica do Ribeirão das Antas são afluentes do Rio Mogi-Pardo, e este por sua vez desagua do Rio Grande e por fim no Rio Paraná. Diagnóstico preliminar nessa sub-bacia hidrográfica tem evidenciado usos múltiplos desse recurso hídrico com possíveis impactos ambientais devido a ações antrópicas, tais como: atividades de mineração (extração de bauxita, de urânio, de argila, de sienitos ornamentais), indústria de produção de fertilizante, produção de matériaprima para garrafas tipo PET, indústrias alimentícias (produtos lácteos e chocolates finos), piscicultura, agricultura com manejo inadequado do solo e utilização intensa de agroquímicos (batata, café e morango), que podem levar ao assoreamento das represas e córregos (IGAM, 2008). Ou seja, essa sub-bacia hidrográfica recebe lançamentos de esgotos resultantes de atividades domésticoindustriais, agrícolas, pecuárias, bem como de efluentes procedentes de mineração. Cerca de 50 \% da energia elétrica consumida na cidade de Poços de Caldas, município com cerca de 140 mil habitantes, é gerada nessa sub-bacia hidrográfica. Além da produção de energia elétrica, esta sub-bacia hidrográfica também é utilizada para captação de água para consumo Humano, visando abastecimento da cidade de Poços de Caldas. Além disso, tratando-se de uma estância hidromineral, dentre as atividades econômicas e turísticas desse município, destaca-se a exploração desse bem.

Com base nas informações acima sobre os usos múltiplos deste corpo aquático, aliado ao fato da falta de estudos científicos na Represa das Antas, o presente trabalho foi realizado visando à caracterização limnológica desse ecossistema, com base em componentes bióticos e abióticos para contribuir com informações sobre a situação atual desse sistema aquático. 


\subsection{Considerações gerais sobre ecologia de reservatórios}

O estudo de sistemas dinâmicos como reservatórios, tem contribuído, e, certamente contribuirá no futuro para a compreensão de problemas básicos em Ecologia, tais como: a sucessão de comunidades em sistemas que apresentam mudanças rápidas, padrões de colonização e efeitos de pulsos. Estas rápidas mudanças produzem uma completa reorganização do sistema, em pouco tempo (dias ou horas) e, consequentemente, é necessário não só acompanhá-las, mas desenvolver mecanismos de previsão, importantes para um melhor aproveitamento econômico. O conhecimento científico dos reservatórios como ecossistemas, suas interações com as bacias hidrográficas e com os sistemas a montante e a jusante, tem adicionado permanentemente novas dimensões à abordagem sistêmica na pesquisa ecológica, proporcionando uma base fundamental para o gerenciamento da qualidade da água e das bacias hidrográficas (TUNDISI, 2007).

Os reservatórios são sistemas híbridos entre rios e lagos e seu estudo deve levar esta característica em consideração (THORNTON et al. 1990). A construção organizada de represas começou há cerca de 100 anos, o que os caracteriza como sistemas artificiais relativamente recentes. Esses ecossistemas artificiais apresentam um padrão dinâmico com rápidas mudanças em seus mecanismos de funcionamento e gradientes horizontais e verticais; fatores de grande importância no estudo das variações sazonais, espaciais e verticais que ocorrem nestes corpos de água (HENRY, 2007).

De acordo com Tundisi (2007), os principais componentes e funções de força que estabelecem as condições de contorno no funcionamento de reservatórios e cujas medidas são essenciais para o entendimento da dinâmica desses ecossistemas, compreendem as características climatológicas da região, o ciclo hidrológico, o tempo de residência e a posição do reservatório (uma vez que há efeitos a montante e a jusante de um reservatório sobre o outro). Os reservatórios são caracterizados por apresentar regiões com influência do rio (a montante), com influência da represa e das descargas (próximas à barragem) ou localizadas no meio do reservatório com funcionamento de lago (TUNDISI et al. 2006). 
No Brasil, os reservatórios têm sido impactados pela entrada de grande carga de nutrientes originados de atividades industriais e de produção agrícola, bem como o aumento populacional com a maior produção de descarga de efluentes provenientes das áreas urbanas. Este processo acarreta a perda da diversidade biológica, altera a cadeia alimentar, aumenta a toxicidade, decresce a qualidade da água e as possibilidades de seus usos múltiplos, modificando o funcionamento do ecossistema como um todo (VELHO et al. 2005).

Espíndola et al. (2002) mostraram, em estudo desenvolvido nos reservatórios em cascata do Rio Tietê (São Paulo), o comprometimento da qualidade da água e do sedimento destes ambientes devido a elevada concentração de nutrientes (fósforo e nitrogênio) e metais. Os primeiros reservatórios do sistema em cascata apresentaram-se mais impactados do que os últimos, devido ao processo de retenção dos elementos na parte superior do sistema.

Em um reservatório urbano (Represa da Pampulha, Belo Horizonte, MG) Rietzler; Fonseca; Lopes (2001) detectaram níveis elevados de metais pesados (zinco, chumbo, cádmio, níquel, cobre, cromo, manganê e ferro) nos tributários da represa e, segundo os autores, estes resultados estavam diretamente ligados às atividades industriais desenvolvidas ao longo de sua bacia de drenagem. Barreto et al. (2008) estudaram o reservatório de Capivara (Rio Paranapanema, Paraná) e demonstraram que os metais manganês e ferro presentes no sedimento nos meses de julho/2002 e fevereiro/2003, bem como fósforo no mês de fevereiro eram liberados para a coluna de água e foram usados como indicadores de influência antropogênica de atividades domésticas e industriais dentro do sistema.

Os reservatórios fazem parte da bacia hidrográfica, captando todos os efeitos das atividades antropogênicas. Nesse sentido, os reservatórios apresentam características próprias e se constituem em um centro coletor dos eventos que ocorrem em seu entorno (TUNDISI, 2007).

De acordo com TUNDISI; BRAGA; REBOUÇAS (2006), o aumento de pesquisas no Brasil para ampliar o conhecimento sobre represas tem sido constante e persistente e os dados gerados devem ser utilizados em programas de monitoramento e de gestão de bacias hidrográficas. Segundo os autores, a progressão dessas atividades deve incluir novas regiões e áreas de pesquisa. Dentro desse enfoque, há uma lacuna ainda a ser preenchida em nosso país; relacionada aos estudos com ênfase em reservatórios que recebem efluentes de 
origem minero-industrial de exploração de jazida de urânio, como é o caso da Represa das Antas, localizada na região sul de Estado de Minas Gerais.

A Represa das Antas (localizada no município de Caldas, MG), inserida no Planalto de Poços de Caldas, é um ambiente singular porque recebe os efluentes líquidos tratados procedentes de rejeitos de mineração da primeira mina de urânio do Brasil. Além disso, o Planalto apresenta anomalias com elevada radioatividade natural, e assim, os corpos de água dessa região podem apresentar níveis de radioatividade natural elevados. A avaliação da qualidade ecológica desta represa é crucial, pois faltam pesquisas em locais próximos às atividades de mineração de urânio no Brasil.

\subsection{Protozooplâncton e relações com outras populações microbianas planctônicas}

Os microorganismos aquáticos são os principais componentes dos ciclos biogeoquímicos globais, regulam suprimento e demanda de carbono orgânico, ciclagem de nutrientes e balanço de gás carbônico e oxigênio dentro dos e entre os ecossistemas. Além disso, estão envolvidos na fixação e na regeneração dos principais constituintes orgânicos celulares (carbono, nitrogênio, enxofre e fósforo) e podem mobilizar elementos essenciais, como as vitaminas, para o crescimento e o metabolismo (BROCK et al. 1994).

Em seu ambiente, os organismos apresentam íntimas e obrigatórias relações com os demais organismos e com as condições físicas e químicas do meio. Modificações nessas relações decorrentes de alterações naturais ou antropogênicas podem conduzir ao desequilíbrio nessas relações. Grande parte dos desequilíbrios ambientais provoca a redução ou até mesmo a extinção de algumas espécies e a dominância de outras. Dessa maneira, os organismos, por apresentarem diferentes graus de sensibilidade aos vários tipos de perturbações no seu ambiente, a diminuição ou o aumento excessivo de algumas espécies podem ser utilizados como bioindicadores da situação atual do sistema (ODUM, 1985).

Em sistemas oligotróficos, diferentes estudos têm demonstrado que as comunidades microbianas planctônicas (bactérias, picoplâncton autotrófico e heterotrófico e protistas) podem ser as responsáveis pela maior parte do carbono 
e produção de energia na zona pelágica do que as clássicas cadeias alimentares "fitoplâncton-metazooplâncton" (FENCHEL, 1988; MODENUTTI et al. 2003).

Associado ao fluxo de biomassa, os protozoários bacterívoros tem se mostrado eficientes mineralizadores de nitrogênio e fósforo, reciclando o carbono e os nutrientes via cadeia alimentar microbiana, sendo especialmente importantes em ecossistemas pobres em nutrientes, como os ambientes oligotróficos, onde as interações tróficas estão tensamente relacionadas (TREMAINE; MILLS, 1991; GONZÁLEZ, 1999; SIMEK et al. 2001).

Devido ao seu reduzido tamanho e altas taxas metabólicas, os protozoários são componentes importantes na ciclagem e regeneração de nutrientes na coluna d'água. Embora frequentemente negligenciados em estudos lacustres, os protozoários têm sido considerados a principal ligação dentro da cadeia alimentar limnética e os níveis tróficos superiores, executando funções significativamente importantes no fluxo de energia e na ciclagem de elementos nos ecossistemas de água doce (XU et al. 2005).

Protozoários bacterívoros ou fagotróficos são importantes nas redes alimentares pelágicas, predando cerca de 80 a $100 \%$ da produção bacteriana diária, sendo considerados os principais responsáveis pela mortalidade e, portanto, uma importante força seletiva para as bactérias aquáticas (JÜRGENS et al. 1999; GONZÁLEZ et al. 1990; SHERR et al. 1992; MATZ; JÜRGENS, 2001 e 2005; CORNO; JÜRGENS, 2006). Além disso, é preciso citar os protistas herbívoros que são capazes de utilizar inúmeras estratégias de alimentação para consumir todos os tamanhos de células autotróficas, incluindo bactérias, dinoflagelados e diatomáceas (SHERR; SHERR, 2002).

O modo de alimentação, o tamanho do alimento e o comportamento mostram amplas variações, indicando que os protozoários compõem um grupo heterogêneo. Havendo nadadores livres bem como espécies que deslizam sobre os substratos e formas anexadas ao substrato (BOENIGK; ARNDT, 2002). Além disso, segundo Tirok; Gaedke (2007), os protozoários estão entre os mais importantes predadores do fitoplâncton, além de remineralizadores de nutrientes em ecossistemas marinhos e de água doce.

Estudos com espécies de protozoários ciliados vêm sendo realizados não somente por serem importantes componentes do plâncton (microzooplâncton) e do bentos de ambientes de água doce, mas também por suas características 
fagotróficas, especialmente por consumir bactérias, algas unicelulares e outros protistas, bem como, por serem predados por rotíferos, cladóceros e copépodos (JÜRGENS, 1994; SÍMEK et al. 1995; MADONI, 1993; MADONI, 2005; XU et al. 2005). Além disso, os protozários ciliados possuem diferentes estratégias para a obtenção de alimento, podendo ser filtradores, sugadores e raptoriais e apresentam um variado espectro de tamanho, resultando em importantes implicações ecológicas quanto a sua função nos sistemas (FENCHEL, 1990).

Elloumi et al. (2006) também relata que os protozoários ciliados constituem uma comunidade amplamente diversificada, o que os proporciona diferentes papéis funcionais no plâncton e a capacidade de ocuparem vários nichos. Em se tratando de seus recursos alimentares, apresentam ampla diversidade, que, além do fitoplâncton e picoplâncton, inclui o bacterioplâncton e, até mesmo algumas espécies do metazooplâncton.

Dentre os protozoários, os ciliados têm se mostrado o grupo mais importante em ecossistemas aquáticos; dominando a biomassa protozooplanctônica com números substanciais, eles são os principais consumidores de bactérias, picoplâncton e nanoplâncton, sendo importantes nas relações tróficas e na ciclagem de nutrientes, através da bacterivoria, algivoria, carnivoria e omnivoria (BIYU, 2000; TAKAMURA et al. 2000; ZINGEL; OTT, 2000; GOMES; GODINHO, 2003; XU et al. 2005).

No Brasil, existem muitos estudos sobre as comunidades planctônicas em reservatórios, porém, poucos deles têm incluído a análise do protozooplâncton na dinâmica da rede trófica. Os protozoários ciliados de água doce são raramente estudados em regiões tropicais, especialmente no Brasil, onde poucos trabalhos têm sido publicados (VELHO et al. 2005; REGALI-SELEGHIM; GODINHO, 2004; ARANTES et al. 2004; HARDOIM; HECKMAN, 1996; BARBIERI; GODINHOORLANDI, 1989; BOSSOLAN; GODINHO, 2000). Isto se dá devido a dificuldades na metodologia, nos métodos de amostragem com redes de plâncton e na utilização de fixadores não satisfatórios (GOMES; GODINHO, 2003).

Recentemente no Brasil, os estudos sobre as comunidades protozooplânctonicas vêm se acelerando, porém, ainda há a falta de pesquisadores trabalhando com a ecologia e/ou taxonomia de protozoários (REGALI-SELEGHIM, 2005). 
Arantes et al. (2004) estudaram durante um ano, a composição taxonômica e as variações no tamanho das populações de protozoários em um reservatório eutrófico (Represa de Salto Grande, Americana - SP). Estes autores relataram predominância de organismos algívoros/bacterívoros, sendo que, de um modo geral, as maiores densidades de protozoários foram registradas na superfície, provavelmente devido à maior disponibilidade de alimento (fitoplâncton). Ainda segundos os autores, as densidades de protozoários foram consideradas baixas quando comparadas a de outros ambientes eutróficos, devido à toxicidade ambiental do sistema comprovada para diversos organismos (microcustáceos, larvas de insetos e peixes), através de testes ecotoxicológicos.

Barbieri; Godinho-Orlandi (1989) relataram em seu estudo num reservatório meso-oligotrófico raso (Represa do Lobo, São Carlos - SP) que nenhuma relação significativa foi verificada entre a distribuição sazonal dos ciliados e amebas e os fatores físicos e químicos.

Hardoim; Heckman (1996) estudaram os efeitos do clima da região norte do Pantanal (Mato Grosso, Brasil) na atividade sazonal dos grupos de protozoários sarcodina e ciliado. Os resultados mostraram que os ciliados foram considerados uma população com baixa diversidade, quando comparados com aqueles presentes em corpos de água da região sudeste do Brasil.

Bossolan; Godinho (2000) demonstraram, em um estudo anual na Lagoa do Infernão (SP), que a composição da comunidade de protozoários e a alta densidade de ciliados ocorreram em sua maior percentagem, na região hipolimnética da lagoa, quando comparada à região superficial. Além disso, verificaram que as maiores densidades de protozoários ciliados foram detectadas entre os meses de julho e setembro. Os autores atribuíram os elevados valores de densidade dos ciliados nestes meses à maior disponibilidade de alimento (bactérias), propiciando a presença de protozoários bacterívoros.

Gomes; Godinho (2003) relacionaram a distribuição sazonal e espacial dos protozoários ciliados e amebas num reservatório raso e eutrófico (Monte Alegre, Ribeirão Preto - SP) com a maior disponibilidade de alimento (bactérias), com as elevadas temperaturas e a menor concentração de oxigênio dissolvido na região hipolimnética desse reservatório.

Regali-Seleghim; Godinho, 2004 estudaram a ocorrência sazonal de ciliados peritriquidas epibiontes sobre o metazooplâncton em um reservatório eutrófico 
raso subtropical (Reservatório do Monjolinho, São Carlos - SP) e segundo os autores, o estudo sugeriu que a epibiose possui um importante papel no controle e na dinâmica das populações planctônicas.

Paiva; Silva-Neto (2004), estudando os protozoários ciliados da Lagoa de Cabiúnas (Macaé - RJ) relataram que dentre as 34 espécies de protistas ciliados encontrados na lagoa, algumas espécies de ciliados foram consideradas indicadoras de qualidade de água, quando aplicado o índice de saprobidade. Os autores concluíram que a lagoa era um ambiente que apresentava características entre alfa-mesosapróbica e polissapróbica. O resultado deste estudo incluiu a descrição da nova espécie de ciliado denominada de Oxytricha marcili sp..

Velho et al. (2005) analisaram a abundância e a biomassa dos ciliados planctônicos em três reservatórios do Estado do Paraná em duas épocas do ano e registraram que, os maiores valores de densidade e biomassa dos ciliados planctônicos foram observados no reservatório do Iraí (eutrófico) e os menores valores no reservatório Chavantes (oligotrófico). Em geral, os ciliados foram mais abundantes na superfície e temporalmente foram observadas diferenças representativas nos valores de densidade, apenas para o reservatório Iraí.

Nos sistemas pelágicos, de acordo com Samuelsson et al. (2006), o fitoplâncton e as bactérias são importantes produtores de novas partículas de matéria orgânica. O destino de grande parte desta produção depende da composição das comunidades consumidoras, dominadas pelos protozoários e pelo metazooplâncton.

De acordo com Azam et al. (1982) o conceito de elo microbiano era visto como um processador de matéria orgânica não viva, via retenção bacteriana, seguida da predação das células bacterianas pelos protozoários. Contudo, segundo Sherr; Sherr (1988) há muitas interações tróficas dentro da rede alimentar microbiana, desta maneira o elo microbiano não pode ser considerado separadamente do resto da cadeia alimentar microbiana. Ao invés disso, os heterótrofos podem ser vistos como responsáveis pela remineralização de parcelas de carbono fixado (células bacterianas e algais) e pela recuperação de carbono fixado (matéria orgânica particulada e dissolvida), por outro lado, o carbono fixado pelas células bacterianas e algais, pode ser transferido para os níveis tróficos superiores. Tais vias de remineralização também incluem retenção de bactérias pelas algas 
mixotróficas e ingestão de pequenos microorganismos contendo cloroplastos pelos ciliados.

O monitoramento das variáveis físicas e químicas proporciona medida instantânea da qualidade da água, no entanto, a análise das variáveis biológicas possibilita a detecção e a integração das interferências que o ambiente sofre continuamente ou intermitentemente. O biomonitoramento utiliza como ferramentas fundamentais diversos índices ecológicos para avaliar o grau de impacto nos corpos d'água (SALUSSO; MORAÑA, 2002).

Aspecto importante na caracterização de um corpo aquático é o seu estado trófico. Usualmente, para se determinar o índice de estado trófico de um corpo aquático são utilizados valores de transparência da água aliado às concentrações de fósforo, de nitrogênio e de clorofila a. De acordo com o valor obtido para o índice de estado trófico, adota-se uma classificação para o ambiente aquático que varia de oligotrófico a hipereutrófico (CARLSON, 1977).

Quando a interpretação do estado trófico é feita em conjunto com outros eventos, especialmente biológicos, pode-se avaliar graus de deterioração do ambiente aquático (qualidade da água) (Kent State University, 2008; MADONI, 1993). Em função disto, outros índices biológicos úteis são utilizados para descrever as condições da qualidade da água, como o índice de saprobidade (RADOCEVIC-NEDOVIC; HOLLERT, 2005). De acordo com Madoni (2005), Lee et al. (2004) e García-Santana; González-Martínez (2002) o índice de saprobidade é capaz de definir a qualidade biológica dos ecossistemas aquáticos através do uso de organismos bioindicadores. Além do estado de trofia e saprobidade de um ambiente aquático, a diversidade na composição dos organismos também pode caracterizar alterações ambientais, tais como: a ausência de gêneros caracterizados como sendo comumente pertencentes a determinado ecossistema, a ocorrência de organismos caracterizados como tolerantes a alterações ambientais, a diminuição no número de indivíduos ao longo do tempo e do espaço e a substitução de determinadas espécies por outras (MADONI, 2005).

Os ciliados têm sido propostos como bioindicadores biológicos de qualidade da água, devido a alta sensibilidade às alterações ambientais quando comparados a outros organismos, devido às altas taxas reprodutivas e variedade de nichos tróficos (bacterívoros, algívoros, carnívoros, omnívoros) que ocupam; podem ser utilizados para monitorar alterações na qualidade da água em curtos períodos de 
tempo devido a sua alta taxa metabólica (GARCÍA-SANTANA; GONZÁLEZMARTÍNEZ, 2002; JIANG; SHEN 2005; LEE et al. 2004; LUGO et al. 1991; MADONI, 1993; MADONI, 2005; SALUSSO; MORAÑA, 2002).

\subsection{Justificativa}

A Represa das Antas (Caldas - M.G.) é um corpo aquático que foi construído para o abastecimento de água para a UTM-INB. Atualmente, a Represa das Antas recebe os efluentes tratados dessa instalação nuclear, procedentes de drenagens ácidas geradas em pilhas de rejeitos de minério da primeira mina de urânio do país. O Brasil ainda não detêm a tecnologia nem a experiência prática sistematizadas na remediação e descomissionamento de minas e usinas de urânio, mas seus órgãos reguladores, nuclear e ambiental, têm a responsabilidade legal de realizar a análise de segurança para determinar as conseqüências, a curto e longo prazo, para humanos e o meio ambiente, associadas às ações de descomissionamento e do fechamento definitivo da instalação propostas pelo empreendedor. Sendo assim, torna-se de imperativo para os órgãos licenciadores e fiscalizadores de instalações nucleares, como é o caso da Comissão Nacional de Energia Nuclear, gerar conhecimento acerca da sub-bacia hidrográfica do Ribeirão das Antas, a fim de subsidiar a tomada de decisões relativas ao tratamento e gerenciamento de rejeitos e efluentes radioativos.

Existem poucas pesquisas que vêm sendo realizadas no Planalto de Poços de Caldas, estas em sua maioria têm sido realizadas dentro da instalação nuclear (UTM-INB) e na região do Morro do Ferro (considerado um dos locais do mundo que apresenta maior radioatividade natural).

Garcia (1989) realizou estudo sobre a lixiviação bacteriana de minério de urânio utilizando espécies provenientes de quatro regiões de mineração brasileira, entre elas a Mina de Urânio a céu aberto Osamu Utsumi em Caldas. Segundo o autor, os minérios estudados na região de Poços de Caldas mostraram-se susceptíveis à lixiviação bacteriana. Souza (1995) evidenciou que a atividade bacteriana nas pilhas de rejeito de mina de urânio de Poços de Caldas eram mais intensas na região em contato com o ar do que na região de saturação, ou seja, a 
geração de ácido na região superior da pilha é governada pelos mecanismos biológicos enquanto que na região inferior predomina os mecanismos químicos. A existência de bactérias redutoras de sulfato em amostras de água, provenientes da Cava da Mina Osamu Utsumi que apresentavam baixos valores de $\mathrm{pH}$ e oxigênio, bem como altas concentrações de metais pesados ( $\mathrm{Mn}$ e Zn) foi demonstrada por Benedetto et al. (2005). Marques (2006) isolando diferentes linhagens de cianobactérias no sistema de tratamento de efluentes da UTM-INB demonstrou a capacidade da linhagem Aphanothece sp. em adsorver ${ }^{226} \mathrm{Ra}$ e a produção de baixas concentrações de epatotoxinas em linhagens da ordem Oscillatoriales. Campos (2006) avaliando a ocorrência e as flutuações das populações bacterianas de Acidithiobacillus ferrooxidans e Acidithiobacillus thiooxidans em efluentes da UTM-INB, observou que $A$. ferrooxidans e $A$. thiooxidans apresentaram variação sazonal, tanto quantitativamente como em relação à sua incidência nos diferentes pontos de coleta avaliados. Segundo o autor, os pontos críticos em relação à ocorrência de drenagem ácida de mina e a ação de bactérias biolixiviantes foram: Cava da Mina (CM), Bacia de Drenagem (D3) e Borra de Enxofre (BS). Estes locais foram considerados pontos críticos em ações de remediação, frente a uma possível ação de descomissionamento.

Vale (1982) testou métodos para análise de espectroscopia $\alpha$ para obter as primeiras informações dos níveis de urânio e tório na água no entorno do Morro do Ferro. Pivetta (1983) detectou os elementos Ca, Fe, Mn e Si em amostras de águas provenientes do Morro do Ferro, sendo que a concentrações desses elementos variaram de acordo com a estação do ano amostrada. Analisando a interação entre o tório e os compostos húmicos em águas naturais subterrâneas e superficiais no Morro do Ferro (Poços de Caldas - MG), Kuchler (1986) verificou que os baixos valores de $\mathrm{pH}$ característicos deste sistema levaram à precipitação do ácido húmico que por sua vez, arrasta consigo o tório presente na solução.

Como enfatizado anteriormente, os trabalhos realizados na região de mineração do Planalto de Poços de Caldas estiveram concentrados na UTM-INB. Poucos estudos abordando o diagnóstico do possível impacto ecológico da UTMINB nos corpos hídricos no entorno têm sido realizados. Prado (1994) já alertava sobre a problemática do impacto causado pelo lançamento dos efluentes líquidos procedentes da mineração de urânio no Ribeirão das Antas devido as elevadas concentrações de $\mathrm{Ba}, \mathrm{Ca}, \mathrm{F}^{-}, \mathrm{Mn}, \mathrm{SO}_{4}$ e atividade de ${ }^{238} \mathrm{U}$. Lage-Filho (1996) 
analisou as características limnológicas (variáveis físicas, químicas, geológicas e o zooplâncton) dos rios pertencentes à sub-bacia hidrográfica do Ribeirão das Antas (Poços de Caldas - MG) no período de menores precipitações e verificou a ocorrência de fontes de poluição nos ribeirões estudados, bem como, uma grande capacidade de autodepuração do ribeirão principal. Segundo este autor, a composição iônica do sedimento do Ribeirão das Antas refletiu tanto os usos da bacia quanto a composição litológica da região. Ronqui (2004) realizou o primeiro estudo visando à caracterização das variáveis físicas, químicas, bem como a biota planctônica da Represa das Antas.

Nesse contexto o presente estudo foi pioneiro na Represa das Antas abordando a caracterização limnológica (variáveis físicas, químicas e biológicas), bem como a determinação do estado de trofia, índice de saprobidade, índice de diversidade e valores de biomassa e densidade de organismos planctônicos, em amostras de água da Represa das Antas.

Os resultados gerados poderão contribuir com as necessidades de informação do Instituto de Gestão de Águas de Minas Gerais para possibilitar o enquadramento desse manancial de acordo com a Resolução 357 do Conama (CONAMA, 2005).

O Brasil não tem experiência sistematizada na remediação e no descomissionamento de mina de urânio, sendo a UTM-INB a primeira mina de urânio em fase de descomissionamento. A localização do Laboratório de Poços de Caldas/CNEN próximo a essa instalação e sua infra-estrutura técnica e laboratorial implantadas, constituiram uma oportunidade singular para a avaliação de possível impacto ambiental causado por efluentes de mina de urânio em subbacia hidrográfica.

\subsection{Objetivo Geral}

O objetivo geral deste estudo foi realizar a caracterização limnológica da Represa das Antas, baseando-se na avaliação da comunidade de protozários ciliados, do dinoflagelado Peridinium sp., do bacterioplâncton, do fitoplâncton e de variáveis físicas e químicas, para a avaliação de efeitos ambientais causados por efluentes de Mina de Urânio sobre populações microbianas planctônicas. 


\subsubsection{Objetivos Específicos}

1 Caracterizar sazonalmente e espacialmente os diferentes gêneros de protozoários ciliados, considerando sua abundância, biomassa e suas interrelações com outros componentes da rede trófica microbiana (densidade e biomassa do dinoflagelado Peridinium sp., os valores de densidade do bacterioplâncton e a estimativa da biomassa fitoplanctônica), bem como com as variáveis físicas e químicas da água na Represa das Antas;

2 Determinar sazonalmente e espacialmente as relações tróficas dos tipos nutricionais no compartimento biótico, presentes em amostras de água da Represa das Antas, considerando os valores de densidade e biomassa dos protozoários ciliados, do dinoflagelado Peridinium sp., os valores de densidade do bacterioplâncton, a estimativa da biomassa fitoplanctônica e deste com a composição química e as características físicas da água na Represa das Antas;

3 Determinar sazonalmente e espacialmente possíveis efeitos do lançamento de efluentes de mina de urânio na Represa das Antas, sobre a diversidade, a abundância e a biomassa de populações microbianas planctônicas, bem como sobre o estado de trofia e a composição química da água, na Represa das Antas;

4 Determinar sazonalmente o Índice de Estado Trófico da Represa das Antas;

5 Determinar sazonalmente e espacialmente o Índice de Diversidade e sazonalmente o Índice de Saprobidade em amostras de água na Represa das Antas.

\section{MATERIAIS E MÉTODOS}

\subsubsection{Descrição do Local de Estudo}

A Represa das Antas (21 $57^{\prime} 30$ "N e 46 31'45" O) como mostra a Figura 1 e o Anexo A, está localizada no Ribeirão das Antas, a cerca de $300 \mathrm{~m}$ a jusante da confluência do Córrego da Cachoeirinha, na divisa dos municípios de Andradas e Caldas, Estado de Minas Gerais, distante aproximadamente $30 \mathrm{~km}$ da cidade de 
Poços de Caldas e $2 \mathrm{~km}$ fora do limite atual da área da UTM/INB (Anexo B: Indústrias Nucleares do Brasil S/A). A Sub-Bacia Hidrográfica do Ribeirão das Antas constitui a maior e principal rede hidrográfica do Planalto de Poços de Caldas, espalhando-se por toda a região centro-ocidental, cobrindo uma área de 422,96 Km² (CHRISTOFOLETTI, 1970).

A denominação Planalto de Poços de Caldas resulta da modelagem diferenciada do relevo. Situado na borda ocidental da Serra da Mantiqueira, em contato com os extremos orientais da bacia sedimentar do Paraná, formando um conjunto morfoestrutural perfeitamente caracterizado, englobando parte do território mineiro e paulista. Geomorfologicamente, a região é caracterizada por um modelado estrutural dômico, com diques anelares individualizado pelas cristas e escarpas abruptas circulares que o delimitam. A área de drenagem da Subbacia Hidrográfica do Ribeirão das Antas é de litologia variada, dominando rochas intrusivas - tinguaítos e foiaitos, principalmente tinguaitos. Já os fonolitos e tufos vulcânicos têm áreas de ocorrência mais restrita (LAGE-FILHO, 1996).

Esse Ribeirão faz parte da bacia hidrográfica do Rio Mogi-Guaçu - Pardo, que deságua no Rio Grande e em seguida, integrando a bacia do Rio Paraná. As margens da Represa e o leito do Ribeirão das Antas são cobertos por aluvião argilo-silto-arenoso (IGAM, 2008).

A Represa das Antas foi barrada em 1982 com a finalidade de abastecimento de água para a UTM-INB. Atualmente, recebe os efluentes tratados da UTM-INB, procedentes de drenagens ácidas geradas de pilhas de rejeitos de mina (também chamadas de pilhas de estéreis) de minério de baixo teor de urânio. Antes da liberação na Represa das Antas, os efluentes recebem tratamento com hidróxido de cálcio visando à precipitação dos metais e radionuclídeos, permanecendo armazenados numa bacia para decantação de sólidos e em seguida, são liberados por gravidade na Represa. De acordo com Cipriani (2002), em 2001 o volume de água ácida tratada na UTM-INB e lançada na Represa das Antas foi de 1.414.851 $\mathrm{m}^{3}$. Os dados hidrológicos e morfométricos da Represa das Antas são mostrados na Tabela 1.

Quanto ao nível de água do reservatório, o vertedouro é um arco de curvatura simples, tendo uma armadura de pele em malha para escoamento da água, possuindo descarga de fundo provida de comporta plana. Esta descarga de fundo permite um esvaziamento do reservatório até a cota de 1,284 m, o que não só se 
constitui em um fator de segurança adicional, como também permite um maior controle quanto aos problemas de eutrofização da água do reservatório (RELATÓRIO AMBIENTAL INB, 1999).

Tabela 1. Dados Hidrológicos e Morfométricos da Represa das Antas, Caldas - MG

\begin{tabular}{c|c}
\hline Corpo Aquático Represado & Ribeirão das Antas \\
\hline Ano do Fechamento & 1982 \\
\hline Altitude & $1291 \mathrm{~m}$ \\
\hline \multicolumn{2}{c}{ Hidrologia } \\
\hline Área de Drenagem & $51 \mathrm{Km}^{2}$ \\
\hline Descarga Máxima do Afluente & $490 \mathrm{~m}^{3} / \mathrm{s}$ \\
\hline Descarga Máxima do Efluente & $180 \mathrm{~m}^{3} / \mathrm{s}$ \\
\hline Descarga mínima garantida para a jusante & $0,125 \mathrm{~m}^{3} / \mathrm{s}$ \\
\hline
\end{tabular}

Morfometria do Reservatório

\begin{tabular}{c|c}
\hline Área inundada & $1,9.10^{6} \mathrm{~m}^{2}$ \\
\hline Volume & $3,9.10^{6} \mathrm{~m}^{3}$ \\
\hline Profundidade Máxima & ${ }^{*} 6,9 \mathrm{~m}$ \\
\hline Profundidade mínima & ${ }^{*} 1,0 \mathrm{~m}$ \\
\hline Comprimento máximo & $3.500 \mathrm{~m}$ \\
\hline Largura média & $250 \mathrm{~m}$ \\
\hline Tempo de Retenção & ${ }^{*} 5 \mathrm{dias}$ \\
\hline Vazão Média Anual & $9,515 \mathrm{~m}^{3} / \mathrm{s}$ \\
\hline
\end{tabular}

Fonte: Relatório Ambiental INB (1999)

*Comunicação Pessoal (RONQUI, 2008).

\subsubsection{Delineamento experimental}

Foram realizadas coletas de amostras de água na Represa das Antas nos meses de janeiro/06, abril/06, julho/06, outubro/06 e fevereiro/07 durante 0 período de um ano. Os pontos de amostragem (Cab, P41, P14 superfície e P14 fundo) são mostrados na Figura 1 e no Anexo $A$. As coletas foram realizadas no período da manhã entre 9:30 e 12:00 h, para a obtenção de informações sobre a comunidade de protozoários ciliados, do bacterioplancton e do dinoflagelado Peridinium sp., bem como foram realizadas determinações de clorofila, de feotitina e de variáveis físicas e químicas.

O ponto cabeceira ( $\mathrm{Cab}$ ) apresenta profundidade igual a $1,50 \mathrm{~m}$, está

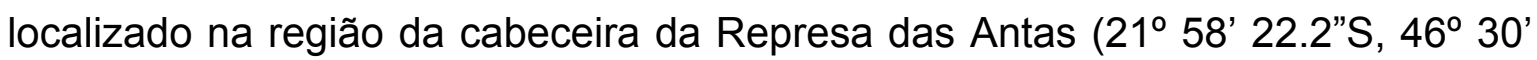


43.7" WO) e não sofre influência direta dos efluentes da mina de urânio. O ponto

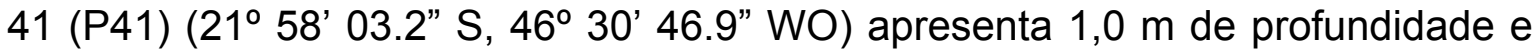
localiza-se na região central da represa, recebendo o efluente tratado da UTMINB. Os pontos de coleta: ponto 14 superfície (P14S) e ponto 14 fundo (P14F) ( $21^{\circ} 87^{\prime} 47.9^{\prime \prime}$ S, $46^{\circ} 31^{\prime} 32.4^{\prime \prime}$ WO) estão localizados à jusante do ponto P41, próximos à barragem, local com 6,9 metros de profundidade (Figura 1 e Anexo A).

As amostras de água foram coletadas a $0,5 \mathrm{~m}$ de profundidade nos pontos Cab, P41 e P14S, bem como a 6,5 m de profundidade no P14F, com garrafa de Van Dorn de $5 \mathrm{~L}$ de capacidade e conduzidas imediatamente para análise no Laboratório de Radioecologia do Laboratório de Poços de Caldas-Comissão Nacional de Energia Nuclear(LAPOC/CNEN).

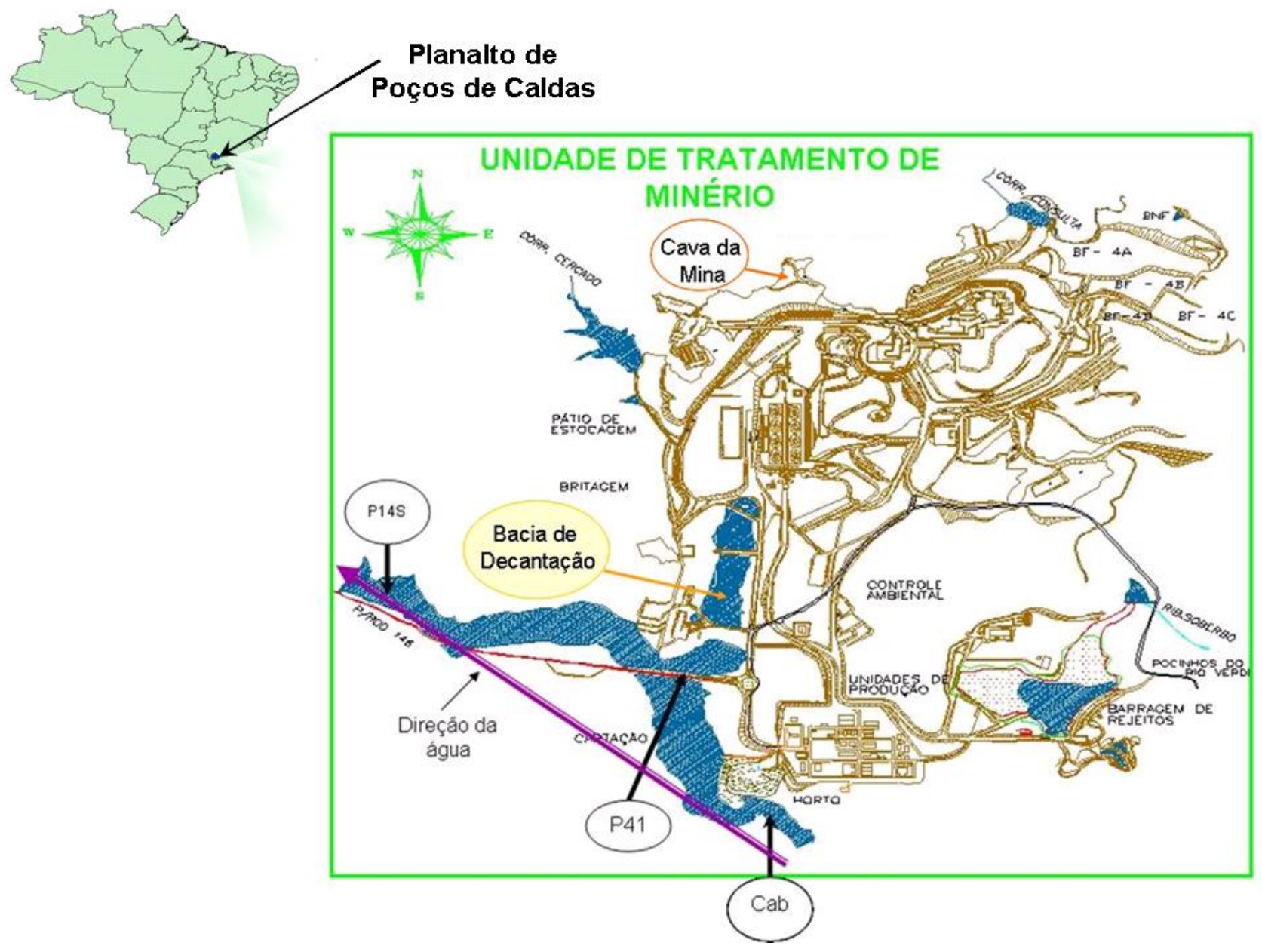

Figura 1. Localização dos pontos de amostragem na Represa das Antas e esquema mostrando as principais instalações da UTM-INB. 


\subsection{Variáveis Físicas e Químicas}

\subsubsection{Parâmetros Meteorológicos}

Todos os resultados dos parâmetros meteorológicos foram fornecidos pela Estação Meteorológica (Campbell Scientific, Modelo CR10X, 815W - 1800N) instalada nas dependências do LAPOC/CNEN. A estação meteorológica coleta informações diariamente, a cada intervalo de 30 minutos, iniciando as medições às 0:30 $\mathrm{h}$ e encerrando às 0:00 h. Localiza-se aproximadamente à $14 \mathrm{Km}$ de distância da UTM-INB e da Represa das Antas.

Os valores obtidos para cada parâmetro meteorológico avaliado foram obtidos através da soma dos valores de índice pluviométrico diário, bem como por meio dos valores médios diários, obtidos para a velocidade do vento, a temperatura do ar, a umidade relativa do ar e evaporação. Os cálculos consideraram as medições realizadas nos vinte e cinco dias anteriores à data de cada coleta de amostras na Represa das Antas. Por exemplo, no mês de janeiro a coleta ocorreu na data de 24/01/06, sendo assim, os cálculos dos valores meteorológicos apresentados no presente estudo são referentes ao período de 30/12/05 a 24/01/06.

\subsubsection{Temperatura, pH, condutividade, oxigênio dissolvido, transparência da água e sólidos em suspensão}

As variáveis temperatura, oxigênio dissolvido e transparência da água foram medidas no campo e, as variáveis $\mathrm{pH}$, condutividade e sólidos em suspensão foram medidas no laboratório, logo após cada coleta.

A temperatura da água e as determinações de $\mathrm{pH}$ foram feitas utilizando-se eletrodo seletivo de $\mathrm{pH}$ combinado com sensor de temperatura (WTW - 320). As medidas de condutividade foram realizadas em condutivímetro da marca Digimed com o uso de eletrodo seletivo.

As determinações de oxigênio dissolvido na água foram realizadas por titulometria, segundo Eaton et al. (1995). Os valores de transparência da água foram obtidos com o auxílio do disco de Secchi de $25 \mathrm{~cm}$ de diâmetro. 
As amostras de água para a estimativa de sólidos em suspensão foram filtradas em membranas de fibra de vidro (Millipore), com $47 \mathrm{~mm}$ de diâmetro. Cada membrana foi previamente seca em mufla, levada a $450{ }^{\circ} \mathrm{C}$ por $1 \mathrm{~h}$, e pesada. Filtrou-se $1 \mathrm{~L}$ de cada amostra e em seguida, cada membrana contendo amostra já filtrada foi levada para secagem em estufa a $110{ }^{\circ} \mathrm{C}$, por $2 \mathrm{~h}$. $\mathrm{O}$ filtro contendo cada amostra foi pesado novamente, transferido para cadinho de porcelana previamente pesado e então, colocado em mufla novamente a $150{ }^{\circ} \mathrm{C}$, por 30 minutos. Em seguida, a temperatura da mufla foi elevada em $50{ }^{\circ} \mathrm{C}$ de hora em hora, até alcançar $450{ }^{\circ} \mathrm{C}$, permanecendo nesta temperatura por 2 horas (TEIXEIRA et al. 1965).

\subsubsection{Dureza, Fósforo Total, Fluoreto, Manganês, Zinco, Sulfato, Urânio e Tório}

A partir de cada ponto de coleta foi realizada amostragem de água (1L) em frascos de plástico opaco, para as análises químicas. As amostras foram conservadas com ácido nítrico $(5 \mathrm{~mL})$ e conduzidas imediatamente para análise no Laboratório de Química Analítica do LAPOC/CNEN.

As análises de dureza (Cálcio e Magnésio), manganês e zinco foram realizadas por espectrometria de absorção atômica por plasma acoplado indutivamente (Varian - modelo Liberty RL Sequencial ICP-OES). Foram filtradas alíquotas de $20 \mathrm{ml}$ de cada amostra e colocadas em beckers para leitura no ICP.

O fósforo total foi determinado pela técnica de Espectrofotometria UV-Visível utilizando como reagente colorimétrico o molibidato de amônio, o qual em contato com o fósforo produz complexo de fósforo-molibidato de amônio, de coloração azul. A leitura da solução foi realizada no comprimento de onda de $600 \mathrm{~nm}$ (ASTM, 1980).

O fluoreto foi estimado pelo método potenciométrico com eletrodo de íon seletivo (NASCIMENTO et al. 1988).

As análises de sulfato foram realizadas por Espectrofotometria UV-Visível. Foi utilizado cloreto de bário como reagente de precipitação, formando sólidos em suspensão. $\mathrm{O}$ complexo formado de $\mathrm{BaSO}_{4}$ foi medido no comprimento de onda de $420 \mathrm{~nm}$ (ASTM, 1980). 
As análises de urânio foram realizadas por Espectrofotometria UV-Visível. As amostras foram tratadas por extração utilizando-se solvente tributilfosfato e submetidas a uma reação com solução do reagente colorimétrico de Arsenazo III. A leitura dos resultados foi realizada no comprimento de onda de $650 \mathrm{~nm}$ (FUKUMA et al. 2001).

Para as análises de tório (Espectrofotometria UV-Visível) alíquotas da amostra na concentração de 1,6 a $8,0 \mathrm{mg} / \mathrm{L}$ que se refere ao intervalo da curva padrão foram tratadas por extração utilizando-se solvente Topotrioctilfosfina e submetidas a reação com solução do reagente colorimétrico de Arsenazo III. A leitura dos resultados foi realizada no comprimento de onda de $665 \mathrm{~nm}$ (FUKUMA et al. 2001).

\subsection{Parâmetros Biológicos}

\subsubsection{Coleta e preparo de amostras para a quantificação e identificação de protozoários ciliados e do dinoflagedo Peridinium sp.}

Para as análises de densidade e biomassa dos protozoários ciliados foram coletadas amostras de água em frascos de vidro $(200 \mathrm{ml})$ com tréplicas em cada ponto de amostragem (Cab, P41, P14S e P14F).

As amostras foram fixadas no campo com $4,3 \mathrm{~mL}$ de solução saturada de cloreto de mercúrio e coradas com 4 gotas de azul de bromofenol (0,04\%) (PACE; ORCUTT, 1981). No laboratório, cada amostra foi deixada em repouso para a sedimentação dos protozoários, de acordo com o recomendado por Margalef (1969). Após o período de sedimentação, o sobrenadante foi descartado dos frascos através de sifonamento com tubo de látex; e a água imediatamente acima do precipitado foi retirada com uma pipeta automática, evitando-se a ressuspensão e agitação da amostra na interface ar-água. O volume restante foi homogeneizado para a contagem dos protozoários em câmaras de SedgwickRafter. De cada amostra coletada, foram preparadas e analisadas 3 câmaras (contendo $1 \mathrm{~mL}$ cada uma) de Sedgwick-Rafter, totalizando a análise do conteúdo de 9 câmaras de Sedgwick-Rafter para cada ponto de amostragem. 
O tempo de sedimentação foi calculado através da fórmula abaixo (MARGALEF, 1969).

$$
\mathrm{T}=3 \times \mathrm{H}
$$

onde: $\mathrm{T}=$ tempo (horas); $\mathrm{H}=$ altura do frasco $(\mathrm{cm})$.

Além da coleta de amostras de água para fixação de material com cloreto de mercúrio, foram coletadas também amostras para observação dos organismos a fresco, procedentes de cada ponto de coleta avaliado. As amostras a fresco foram analisadas no dia de coleta. Para a coleta de amostras utilizou-se rede de plancton com $10 \mu \mathrm{m}$ de poro e filtrou-se cerca de $5 \mathrm{~L}$ de amostra de água a partir de cada local de amostragem.

\subsubsection{Identificação dos Protozoários Ciliados e Estimativa da Densidade, do Biovolume e da Biomassa}

Os protozoários foram quantificados e identificados. Para auxiliar na identificação dos protozoários ciliados, estes foram observados em amostras "a fresco", em aumento de 125X, provenientes de amostras de água filtradas em redes de plâncton de $10 \mu \mathrm{m}$ de póro. Alíquotas $(1 \mathrm{~mL})$ foram colocadas em câmara de Sedgwick-Rafter sem adição de lamínula e analisadas sob microscópio ótico (Ortoplan - LEITZ) anotando-se o tipo de movimento, a presença de vacúolo alimentar, a presença de vacúolos contrácteis e outras estruturas celulares. As principais fontes de literatura utilizadas para a identificação dos protozoários ciliados foram: Edmondson (1959); Foissner; Berger (1996); Lee et al. (1985) e Pennak (1953).

Para a estimativa de densidade, foram colocadas alíquotas de $1 \mathrm{~mL}$, de cada amostra fixada com cloreto de mercúrio, em câmaras de Sedgwick-Rafter. Em seguida cada amostra assim preparada foi analisada em microscópio ótico (marca Ortoplan - LEITZ aumento de 125X), sob microscopia de campo claro. A partir de amostras de água procedentes de cada ponto de coleta, bem como de cada mês de coleta avaliado ao longo deste estudo, foram realizadas medidas lineares de aproximadamente 20 indivíduos para cada grupo morfológico. 
A estimativa do volume de cada célula foi feita utilizando-se fórmulas matemáticas que representassem as formas geométricas mais próximas à morfologia dos organismos, segundo Regali-Seleghim (1992), como mostra a tabela do Anexo C. Para a estimativa de biomassa protozooplanctônica, inicialmente os valores de volume de cada protozoário foram multiplicados pelo fator de conversão para carbono, estimado por Putt; Stoecker (1989), que é específico para protozoários ciliados, gerando o valor de biomassa celular. Em seguida, a biomassa celular de cada protozoário foi multiplicada pelo valor de sua densidade.

Utilizando-se a fórmula fornecida por Sorokin; Kadota (1972), chegou-se à biomassa úmida total ( $\left.\mu \mathrm{g} \mathrm{C} . \mathrm{L}^{-1}\right)$, para cada amostra:

$$
B=D \times b
$$

Equação (2)

onde:

$\mathrm{B}=$ biomassa total $\left(\mu \mathrm{g} \mathrm{C.} \mathrm{L}^{-1}\right)$;

$D=$ densidade (ind. $\left.L^{-1}\right) e$

$\mathrm{b}=$ biovolume.

\subsubsection{Estimativa de Densidade, Biovolume e Biomassa do dinoflagelado Peridinium sp.}

O dinoflagelado Peridinium sp. foi quantificado e identificado juntamente com os protozoários ciliados. A literatura utilizada para a identificação do dinoflagelado foi Laybourn-Parry (1992).

Para a estimativa de densidade, foram colocadas alíquotas de $1 \mathrm{~mL}$, de cada amostra fixada com cloreto de mercúrio, em câmaras de Sedgwick-Rafter. Em seguida cada amostra assim preparada foi analisada em microscópio ótico (marca Ortoplan - LEITZ, aumento de 125X), sob microscopia de campo claro. A partir de amostras de água procedentes de cada ponto de coleta, bem como de cada mês de coleta avaliado ao longo deste estudo, foram realizadas medidas lineares de 20 indivíduos para cada grupo morfológico. 
A estimativa do volume de cada célula foi feita utilizando-se a fórmula matemática que representasse a forma geométrica mais próxima à morfologia dos flagelados. Sendo assim, a estimativa do volume de cada célula de dinoflagelado foi realizada através de medidas lineares de largura e comprimento, utilizando o formato elipsóide rotacional descrita por Weisse (1997) como mostra o Anexo C.

Para a estimativa de biomassa do dinoflagelado Peridinium sp., inicialmente os valores de volume de cada dinoflagelado foi multiplicado pelo fator de conversão para carbono, estimado por Borsheim; Bratbak (1987), que é específico para flagelados heterotróficos, gerando o valor de biomassa celular. Em seguida, a biomassa celular de cada dinoflagelado foi multiplicada pelo valor de sua densidade.

Utilizando-se a fórmula fornecida por Sorokin; Kadota (1972), chegou-se à biomassa úmida total ( $\mu \mathrm{g} \quad \mathrm{C} . \mathrm{L}^{-1}$ ), para cada amostra (fórmula descrita anteriormente):

\subsubsection{Coleta, preparo de amostras e estimativa da densidade bacteriana}

Para a análise do bacterioplâncton foram coletadas amostras (100 mL) em frascos esterilizados, fixadas no campo com $5 \mathrm{~mL}$ de formaldeído (concentração de $38 \%$ ), à uma concentração final da amostra de $1,8 \%$ e mantidos em refrigerador $\left( \pm 8{ }^{\circ} \mathrm{C}\right)$ (SHERR; SHERR, 1993), até o momento da análise, que levou de 2 a 3 meses.

Alíquotas de $1 \mathrm{~mL}$ de cada amostra fixadas com formaldeído foram coradas com solução aquosa do corante laranja de acridina (concentração do corante 1 g.L ${ }^{-1}$ ) na concentração final de 0,05 g.L ${ }^{-1}$ (DALEY; HOBBIE, 1975). Após 5 minutos de contactação em tubo de ensaio de $10 \mathrm{~mL}$, a amostra foi filtrada em membrana de policarbonato $0,22 \mu \mathrm{m}$ de poro (Millipore) (HOBBIE et al. 1977), previamente coradas com Sudam Black (Anexo D).

A membrana foi em seguida colocada sobre lâmina fina com a adição de óleo de imersão de baixa fluorescência (marca Cargilli), sem a adição de lamínula e analisada sob microscópio de epi-fluorescência (Microscópio Zeiss-Axioplan 2, filtro UV 450 - 490, FT 510, LP 520, lâmpada de mercúrio HBO 50W e objetiva 
neofluar $100 \times 10=1000 X)$. Foram contados 50 campos microscópicos, de modo que a área de cada campo foi de $625 \mu \mathrm{m}^{2}$.

A estimativa de densidade foi dada segundo a fórmula para o cálculo do número de bactérias $/ \mathrm{mL}$ de amostra:

$$
N=\frac{g \times A \times D}{a \times V}
$$

onde:

$\mathrm{N}=\mathrm{n}^{\circ}$ de bactérias $/ \mathrm{ml}$

$\mathrm{g}=$ média do $\mathrm{n}^{\circ}$ de bactérias/50campos;

$A=$ área de filtração $\left(176,0 \mathrm{~mm}^{2}\right)$;

$\mathrm{d}=$ fator de diluição;

$\mathrm{a}=$ área do campo;

$\mathrm{V}=$ volume filtrado.

Os valores de densidade das bactérias apresentados em número de bactérias por $m L$ (ind. $\mathrm{mL}^{-1}$ ) foram convertidos para número de bactérias por litro (ind. $\mathrm{L}^{-1}$ ).

\subsubsection{Tipos Nutricionais dos Protozoários Ciliados e do dinoflagelado Peridinium sp.}

Os diferentes tipos nutricionais dos protozoários ciliados e do dinoflagelado Peridinium sp., registrados em amostras de água da Represa das Antas, foram classificados em categorias tróficas, de acordo com Foissner; Berger (1996) e segundo Laybourn-Parry (1992), respectivamente.

Os valores percentuais médios de densidade e biomassa dos protozoários ciliados foram calculados para cada mês considerando a somatória dos valores de densidade, bem como para os valores de biomassa total dos diferentes tipos nutricionais de protozoários ciliados registrados em cada mês avaliado.

Para o dinoflagelado Peridinium sp., os valores percentuais médios de densidade e biomassa foram calculados para cada mês considerando a somatória dos valores de densidade, bem como para os valores de biomassa total do tipo nutricional do dinoflagelado Peridinium sp. registrados em cada mês avaliado. 


\subsection{6 Índice de Diversidade}

O valor de índice de diversidade para os protozoários ciliados foi calculado de acordo com Shannon-Weaver (ODUM, 1985), utilizando-se a equação descrita abaixo:

$$
\mathrm{H}=-\Sigma(\mathrm{ni} / \mathrm{N}) \log (\mathrm{ni} / \mathrm{N}) \text { ou }-\Sigma \mathrm{Pi} \log \mathrm{Pi}
$$

onde:

$\mathrm{ni}$ = valor de biomassa de cada gênero em cada ponto amostrado, nos diferentes meses avaliados,

$\mathrm{N}=$ total dos valores de biomassa de protozoários ciliados em cada ponto amostrado nos diferentes meses avaliados e,

$\mathrm{Pi}$ = probabilidade de importância de cada espécie (ni / N).

\subsection{7 Índice de saprobidade}

A fórmula utilizada para o cálculo do Índice de Saprobidade abordando os protozoários ciliados foi a descrita por Pantle; Buck (1955).

$$
\text { SIPB }=\frac{\Sigma(N \times S I)}{\Sigma N}
$$

onde:

$\mathrm{N}$ = estimativa individual do número de cada espécie; 1 = poucos, 3 = muitos e $\mathrm{S}$ = abundante (também pode ser usada a biomassa);

SI = índice de saprobidade das espécies (a cada espécie é atribuído um valor específico), segundo Lee; Soldo (1992);

SIPB = índice de saprobidade de Pantle e Buck.

Á partir do valor do SIPB tem-se a seguinte classificação:

SIPB: 1,0 - 1,5 Limpos = oligosapróbico = qualidade da água Classe I; coloração azul.

1,5 $-2,5$ Moderadamente poluídos $=$ beta-mesosaprobico $=$ qualidade $\mathrm{da}$ água Classe II; coloração verde. 
2,5 - 3,5 Muito Poluídos = alfa-mesosapróbico = qualidade da água Classe III; coloração amarela.

3,5 $-\geq 4,0$ Pesadamente Poluído = polisapróbico = qualidade da água Classe IV; coloração vermelha.

\subsection{8 Índice de estado trófico}

O índice de estado trófico (IET) da Represa das Antas foi calculado de acordo com Carlson (1977), modificado por Toledo et al. (1983). Os parâmetros utilizados para o cálculo deste índice foram os valores de transparência da água (TranS) e as concentrações de clorofila a $(\mathrm{Cl} a)$.

As equações utilizadas para o cálculo do IET foram as seguintes:

$$
\begin{aligned}
& \operatorname{IET}(\operatorname{TranS})=10 x\{6-\{(0,64+\operatorname{InT} \operatorname{TranS}) / \ln 2]\} \quad \text { Equação (6) } \\
& \mathrm{IET}(\mathrm{Cl} a)=10 x\{6-[(2,04-0,695 x \ln \mathrm{Cla}) / \ln 2]\} \quad \text { Equação }(7)
\end{aligned}
$$

onde:

IET = índice de estado trófico;

TranS = transparência da água determinada através do disco de Secchi,

$\mathrm{Cl} \mathrm{a}=$ concentração de clorofila a e;

In = logaritmo natural.

A partir dos valores de IET, os critérios para a classificação trófica foram:

IET $\leq 44$ : oligotrófico;

IET $44<$ IET < 54: mesotrófico;

$\mathrm{IET} \geq 54$ : eutrófico.

\subsection{Clorofila e Feofitina}


A clorofila e a feofitina foram determinadas segundo as recomendações de Marker et al. (1980), utilizando-se etanol $90 \%$ a quente como solvente para a extração.

As concentrações de clorofila a e feofitina foram calculadas através das equações descritas por Lorenzen (1967):

$$
\begin{gathered}
\mathrm{Cl} a=\mathrm{A} \times \mathrm{K} \times\left(665_{0}-665_{\mathrm{a}}\right) \times v / \mathrm{V}_{\mathrm{f}} \times I \\
\mathrm{Feo}=\mathrm{A} \times \mathrm{K} \times\left(\mathrm{R}\left[665_{\mathrm{a}}\right]-665_{0}\right) \times v / \mathrm{V}_{\mathrm{f}} \times I
\end{gathered}
$$

onde:

$A=$ coeficiente de absorção da clorofila $a=11,0$;

$\mathrm{K}$ = fator para igualar a redução na absorbância da concentração da clorofila inicial, 1,7:0,7, ou 2,43,

$665_{0}=$ absorbância antes da acidificação,

$665_{\mathrm{a}}$ = absorbância após a acidificação,

$V=$ volume do solvente utilizado para extração $\left(\mathrm{mL}^{-1}\right)$,

$V_{\mathrm{f}}=$ litro de água filtrada,

$I$ = direção do comprimento da curva $(\mathrm{cm})$,

$\mathrm{R}=$ razão máxima de $665_{0}: 665_{\mathrm{a}}$ na ausência de feopigmentos, 7,7 .

Os valores de clorofila $b$ e $c$ foram calculados através das equações tricromáticas de Jeffrey e Humphrey (1975):

$$
\begin{aligned}
& \text { Cl } b=5,43 E_{664}-21,03 E_{647}-2,66 E_{630} \\
& C l c=-1,67 E_{664}-7,60 E_{647}-24,52 E_{630}
\end{aligned}
$$$$
\text { Equação (10) }
$$

\subsubsection{Estimativa de Biomassa Fitoplanctônica}

Para a estimativa dos valores de biomassa fitoplactônica os valores de clorofia a foram transformados em carbono, utilizando-se o fator de conversão de 67 (EATON et al. 1995). 


\subsection{Análise Estatística}

A análise de variância (ANOVA) foi aplicada para detectar diferenças entre valores determinados nas análises biológicas, físicas e químicas, em amostras de água procedentes dos diferentes pontos e períodos de amostragem. Foram consideradas significativas diferenças apresentando $P<0,05$. A Análise de Correlação de Pearson foi empregada para determinar possíveis correlações entre valores determinados nas análises biológicas, físicas e químicas, em amostras de água procedentes dos diferentes pontos e períodos de amostragem.

\subsubsection{Análise de Variância}

A Análise de Variância foi realizada seguindo o modelo:

$$
y_{i j k}=u+L_{i}+P_{j}+L P_{i j}+e_{i j k} \text {. }
$$

onde:

$y_{\mathrm{ijk}}=$ é a observação da variável y no local; período; na repetição k,

$\mathrm{u}=$ constante geral (média de todas as observações para a variável $\mathrm{y}$,

$\mathrm{L}_{\mathrm{i}}=$ é o efeito do i-ésino local,

$P_{j}=$ é o efeito da j-ésino período,

$L P_{i j}=$ é o efeito da interação do local; como o período j,

$e_{\mathrm{ijk}}=$ é o efeito dos fatores não controlados (ambientais).

As variáveis que apresentaram coeficiente de variação menor do que $30 \%$ foram consideradas na discussão dos resultados, somente para associações que apresentaram diferenças significativas, ou seja, $\mathrm{P}<0,05$.

\subsubsection{Análise de Correlação de Pearson}

A análise estatística utilizada foi a determinação do Coeficiente de Correlação de Pearson $(p<0,05)$, também chamado de "coeficiente de correlação produtomomento" ou simplesmente de "r de Pearson" que mede o grau da correlação (e a direção dessa correlação - se positiva ou negativa) entre duas variáveis de escala métrica (intervalar ou de razão: coeficiente entre dois valores que permite 
estabelecer relações entre os mesmos). Utilizou-se o programa Excel versão Microsoft Windows XP 2000.

No presente estudo seguiu-se Lapponi (1995) para descrever as correlações entre as variáveis analisadas, como mostra o quadro abaixo:

\begin{tabular}{|cl|}
\hline Valor de $\rho(+$ ou -$)$ & \multicolumn{1}{c|}{ Interpretação } \\
\hline 0.00 a 0.19 & Uma correlação bem fraca \\
0.20 a 0.39 & Uma correlação fraca \\
0.40 a 0.69 & Uma correlação moderada \\
0.70 a 0.89 & Uma correlação forte \\
0.90 a 1.00 & Uma correlação muito forte \\
\hline
\end{tabular}

\section{RESULTADOS}

\subsection{Parâmetros Meteorológicos}

De acordo com os parâmetros meteorológicos (índice pluviométrico e temperatura do ar) verificados na região da Represa das Antas, foram identificadas duas estações ao longo dos meses avaliados: uma seca e fria (julho/06) e uma estação quente e úmida (janeiro/06, outubro/06 e fevereiro/07), como mostra a Tabela 2.

Os valores de umidade relativa do ar, evaporação e velocidade do vento apresentaram-se relativamente constantes ao longo de todo o período de estudo avaliado. Exceção foi verificada para a variável meteorológica evaporação do ar no mês de fevereiro de 2007, onde foi registrado o menor valor de evaporação do ar (Tabela 2). 
Tabela 2. Parâmetros Meteorológicos na região da Represa das Antas

\begin{tabular}{|c|c|c|c|c|c|c|}
\hline & & $(\mathrm{mm})$ & $\left({ }^{\circ} \mathrm{C}\right)$ & (\%) & $(\mathrm{m} / \mathrm{s})$ & $(\mathrm{mm})$ \\
\hline \multirow[t]{2}{*}{ ANO } & DIA/MÊS & Ind. PLUV. & TEMP. ar & U. RELAT. & VEL.VEN. & EVAPORAÇÃO \\
\hline & & Soma & \multicolumn{4}{|c|}{ Media \pm Desvio Padrão } \\
\hline 2006 & Janeiro & 324,11 & $19,40 \pm 4,40$ & $100,97 \pm 153,31$ & $1,52 \pm 3,66$ & $16,65 \pm 172,37$ \\
\hline 2006 & Abril & $169,94^{*}$ & $17,55 \pm 40,10$ & $109,33 \pm 184,85$ & $1,42 \pm 3,34$ & $18,94 \pm 176,16$ \\
\hline 2006 & Julho & $9,65^{* *}$ & $11,78 \pm 6,68$ & $101,17 \pm 156,42$ & $1,13 \pm 3,10$ & $14,53 \pm 115,60$ \\
\hline 2006 & Outubro & 362,71 & $17,95 \pm 3,96$ & $104,42 \pm 153,82$ & $1,60 \pm 3,35$ & $21,21 \pm 200,53$ \\
\hline \multirow[t]{2}{*}{2007} & Fevereiro & 229,61 & $19,42 \pm 3,49$ & $83,12 \pm 14,78$ & $1,07 \pm 0,76$ & $0,004 \pm 0,01$ \\
\hline & Escala Beaufort & & & & Calmaria/bafagem & \\
\hline
\end{tabular}

\subsection{Variáveis Físicas e Químicas}

Em relação aos valores registrados para sólidos em suspensão em amostras de água da Represa das Antas (Tabela 3), o maior valor médio foi observado no mês de fevereiro $\left(0,014 \mathrm{mg} \cdot \mathrm{L}^{-1}\right)$ e o menor valor médio foi detectado em amostras de água coletadas no mês de julho $\left(0,003 \mathrm{mg} \cdot \mathrm{L}^{-1}\right)$.

Os valores de transparência da água variaram de $0,5 \mathrm{~m}$ (P41) a 3,5 m (P14S). Para os pontos Cab e P41 os valores registrados de transparência da água corresponderam ao valor de profundidade destes pontos, ao longo de todo o período estudado (Tabela 3).

Para os valores médios de condutividade elétrica obtidos em amostras de água da Represa das Antas, os maiores valores foram registrados em julho $\left(411 \mu \mathrm{S} . \mathrm{cm}^{-}\right.$ $\left.{ }^{1}\right)$ seguido de fevereiro $\left(360,5 \mu \mathrm{S} . \mathrm{cm}^{-1}\right)$ (Tabela 3). Tais valores de condutividade elétrica foram significativamente diferentes $(P<0,05)$ daqueles valores médios registrados em outubro $\left(192 \mu \mathrm{S} . \mathrm{cm}^{-1}\right)$ e janeiro $\left(144 \mu \mathrm{S} . \mathrm{cm}^{-1}\right)$. Espacialmente não foram verificadas diferenças significativas $(P>0,05)$ entre os valores de condutividade elétrica da água, registrados em amostras prodecentes dos diferentes pontos de coleta.

De acordo com o Plano Nacional de Recursos Hídricos (BRASIL, 2006) os corpos de água localizados na Sub-Bacia Hidrográfica do Ribeirão das Antas são 
considerados como de Classe II, frente à Resolução 357 do Conama (CONAMA, 2005), uma vez que ainda não passaram por instrumento normativo de enquadramento. Neste contexto, os resultados obtidos no presente trabalho foram comparados com os limites estabelecidos pela norma acima citada, adotando-se os limites previstos para corpos de água de Classe II.

Em relação aos valores de $\mathrm{pH}$, o valor médio máximo obtido em amostras de água da Represa das Antas foi registrado no mês de outubro $(6,6)$ e apresentouse significativamente maior $(P<0,05)$ do que o menor valor médio de $\mathrm{pH}(5,6)$, registrado em amostras de água coletadas no mês fevereiro (Tabela 3). Espacialmente não foi verificada diferença significativa $(P>0,05)$ para os valores de $\mathrm{pH}$ registrados em amostras de água procedentes dos diferentes pontos avaliados. Somente no mês de fevereiro foram registrados valores de $\mathrm{pH}$ mais ácidos e fora dos limites permitidos pela Resolução 357 do Conama (CONAMA, 2005) para amostras de água coletadas nos pontos P41, P14S e P14F.

Os resultados mostraram que, o maior e o menor valor médio de temperatura da água $(P<0,05)$ foi registrado, respectivamente, em amostras de água coletadas no mês de outubro $\left(26,0^{\circ} \mathrm{C}\right)$ e julho $\left(16,3^{\circ} \mathrm{C}\right)$. Houve diferença significativa $(P<0,05)$ quando comparado o maior e o menor valor médio de temperatura.

Nos meses de janeiro/06, abril/06 e fevereiro/07, os valores médios de temperatura da água apresentaram-se relativamente constantes $(P>0,05)$, ou seja, em torno de $23,5^{\circ} \mathrm{C}$, mas diferentes $(P<0,05)$ dos valores detectados em amostras de água coletadas em outubro e julho. Espacialmente, os resultados mostraram que os valores de temperatura observados nas amostras de água procedentes dos pontos Cab e P14F foram em média, significativamente menores $(P<0,05)$ do que aqueles observados nos pontos P41 e P14S (Tabela 3).

Em relação aos valores de oxigênio dissolvido da água, o maior e o menor valor médio detectado ocorreu, respectivamente, em amostras de água coletadas no mês de outubro $\left(8,5 \mathrm{mg} \cdot \mathrm{L}^{-1}\right)$ e abril $\left(4,7 \mathrm{mg} \cdot \mathrm{L}^{-1}\right)$ (Tabela 3$)$, sendo verificada diferença significativa $(P<0,05)$ quando comparados 0 valor médio registrado nesses dois meses. Nos meses de janeiro/06, julho/06 e fevereiro/7 os valores médios de oxigênio dissolvido registrados nas amostras de água provenientes da Represa das Antas não apresentaram diferença significativa entre si $(P>0,05)$, entretanto, apresentaram diferença significativa $(P<0,05)$ em relação aos valores 
detectados em outubro e abril. Espacialmente, foram verificadas diferenças significativas $(P<0,05)$ entre os valores de oxigênio dissolvido determinados em amostras de água coletadas nos pontos P41 e P14F, nos pontos P41 e Cab e nos pontos P14S e P14F. Somente o valor médio de concentração de oxigênio dissolvido na água registrado em amostras de água coletadas em abril, esteve abaixo do limite mínimo estabelecido pela Resolução 357 do Conama (CONAMA, 2005).

Os métodos analíticos utilizados no presente estudo para a determinação de fósforo total, zinco, manganês, urânio e tório apresentaram baixa sensibilidade, sendo assim, o limite de detecção dos métodos, nem sempre possibilitaram a determinação de um valor exato de concentração desses elementos químicos (Tabela 4).

O valor médio obtido para fluoreto em amostras de água coletadas em abril $\left(6,8 \mathrm{mg} \cdot \mathrm{L}^{-1}\right)$ foi significativamente maior $(\mathrm{P}<0,05)$ do que o valor médio registrado em janeiro $\left(1,5 \mathrm{mg} \cdot \mathrm{L}^{-1}\right)$, como mostra a Tabela 4. Quanto à variação espacial, o valor médio de concentração de fluoreto, ou seja, $0,74 \mathrm{mg} \cdot \mathrm{L}^{-1}$, obtido para amostras de água procedentes do ponto $\mathrm{Cab}$ foi, significativamente menor $(\mathrm{P}<0,05)$ do que os valores médios registrados nos ponto $\mathrm{P} 14 \mathrm{~F}\left(5,27 \mathrm{mg} \cdot \mathrm{L}^{-1}\right) \mathrm{e}$ P41 (6,28 mg. $\left.\mathrm{L}^{-1}\right)$.

Excetuando os resultados de fluoreto obtidos no mês de abril e fevereiro, respectivamente, para amostras de água procedentes dos pontos Cab, P41 e Cab, todos os demais valores de fluoreto estiveram acima do limite previsto pela Resolução 357 do Conama (CONAMA, 2005).

Em relação aos resultados obtidos para a variável manganês, o maior valor médio foi registrado em amostras de água coletadas no ponto P41 (valor igual a $\left.5,13 \mathrm{mg} \cdot \mathrm{L}^{-1}\right)$, tal valor foi significativamente maior $(\mathrm{P}<0,05)$ quando comparado àqueles registrados para amostras de água procedentes dos pontos $\mathrm{P} 14 \mathrm{~S}(1,70$ mg. $\left.\mathrm{L}^{-1}\right)$ e Cab $\left(0,76 \mathrm{mg} \cdot \mathrm{L}^{-1}\right)$. Todos os valores de concentração de manganês em amostras de água, registrados acima do limite de detecção do método utilizado no presente estudo, apresentaram-se acima do limite previsto pela Resolução 357 do Conama (CONAMA, 2005), como mostra a Tabela 4. 
Somente no mês de fevereiro, para amostras de água procedentes do ponto P41 (2,03 mg. $\left.\mathrm{L}^{-1}\right)$, foi verificado valor de zinco acima do limite previsto pela Resolução 357 do Conama (CONAMA, 2005).

$\mathrm{O}$ valor médio detectado para sulfato em amostras de água coletadas no mês de julho $\left(226 \mathrm{mg} \cdot \mathrm{L}^{-1}\right)$ foi significativamente maior $(P<0,05)$ do que aquele registrado em amostras procedentes do mês de abril $\left(22,35 \mathrm{mg} \cdot \mathrm{L}^{-1}\right)$. Em geral, as amostras de água procedentes do ponto P41 apresentaram os maiores valores de sulfato (valor médio igual a $169,89 \mathrm{mg} \cdot \mathrm{L}^{-1}$ ) e aquelas do ponto Cab, os menores $\left(75 \mathrm{mg} . \mathrm{L}^{-1}\right)$. Os valores de sulfato obtidos em amostras de água procedentes do ponto P41 (169,89 mg. $\left.\mathrm{L}^{-1}\right)$ e a jusante desse, ou seja, em amostras procedentes dos pontos P14S (104,13 mg. $\left.\mathrm{L}^{-1}\right)$ e P14F $\left(107,65 \mathrm{mg} . \mathrm{L}^{-1}\right)$ foram signficativamente maiores $(P<0,05)$, do que o valor médio registrado em amostras coletadas no ponto $\mathrm{Cab}\left(75,53 \mathrm{mg} \cdot \mathrm{L}^{-1}\right)$. Somente os valores de sulfato detectados nas amostras de água coletadas no ponto P41 para o mês de julho $\left(278,7 \mathrm{mg} \cdot \mathrm{L}^{-1}\right)$ e fevereiro (412,3 mg. $\left.\mathrm{L}^{-1}\right)$ estiveram acima do limite previsto pela Resolução 357 do Conama (CONAMA, 2005), como mostra a Tabela 4.

Os valores de urânio registrados em amostras de água coletadas na Represa das Antas no mês de abril para os pontos Cab $\left(0,11 \mathrm{mg} \cdot \mathrm{L}^{-1}\right)$ e P41 $\left(0,11 \mathrm{mg} \cdot \mathrm{L}^{-1}\right)$, bem como em outubro, para amostras de água procedentes dos pontos Cab $(0,08$ $\left.\mathrm{mg} \cdot \mathrm{L}^{-1}\right)$, P41 (0,06 mg. $\left.\mathrm{L}^{-1}\right)$ e P14S $\left(0,06 \mathrm{mg} \cdot \mathrm{L}^{-1}\right)$ estiveram acima dos limites estabelecidos pela Resolução 357 do Conama (CONAMA, 2005), como mostra a Tabela 4.

Em amostras de água procedentes dos pontos Cab no mês de janeiro e para o ponto P14F em julho foram registrados valores de tório acima do limite previsto pelo Ofício $n^{\circ}$ 50/SLC de junho de 1997 da Comissão de Energia Nuclear, ou seja, respectivamente, $0,03 \mathrm{mg} \cdot \mathrm{L}^{-1}$ e 0,06 mg. $\mathrm{L}^{-1}$ (Tabela 4).

Os resultados obtidos para a variável dureza da água (Tabela 4) demonstraram que o valor médio registrado em julho (239 $\mathrm{mg}^{-\mathrm{L}^{-1}}$ ) foi significativamente diferente $(P<0,05)$ daquele detectado no mês de abril $(26,85$ $\left.\mathrm{mg} \cdot \mathrm{L}^{-1}\right)$. Espacialmente, o valor médio de dureza registrado em amostras de água procedentes do ponto P41 $\left(180,07 \mathrm{mg} \cdot \mathrm{L}^{-1}\right)$ foi significativamente maior $(P<0,05)$ do que o valor médio registrado em amostras do ponto $\mathrm{Cab}\left(77,86 \mathrm{mg} \cdot \mathrm{L}^{-1}\right)$. Em geral, 
os maiores valores de dureza (Tabela 4) e de condutividade elétrica da água (Tabela 3) foram registrados no ponto P41.

As concentrações de fósforo total $\left(<0,01 \mathrm{mg} \cdot \mathrm{L}^{-1}\right)$ nas amostras de água provenientes da Represa das Antas apresentaram-se dentro do limite estabelecido pela Resolução 357 do Conama (CONAMA, 2005), como mostra a Tabela 4.

Tabela 3. Valores de temperatura, de pH, de oxigênio dissolvido, de condutividade elétrica, de sólidos em suspensão e de transparência em amostras de água da Represa das Antas, coletadas em diferentes pontos de amostragem.

\begin{tabular}{|c|c|c|c|c|c|c|c|}
\hline Meses & Pontos & $\mathrm{T}^{\circ} \mathrm{C}$ água & pH & $\begin{array}{l}\text { Oxigênio } \\
\text { (mg/L) }\end{array}$ & Cond. (uS. $\mathrm{cm}^{-1}$ ) & S S $\left(\mathrm{mg} \cdot \mathrm{L}^{-1}\right)$ & $\begin{array}{c}\text { Trans - } \\
\text { Secchi (m) }\end{array}$ \\
\hline \multirow{4}{*}{ Janeiro } & Cab & 24,8 & 6,3 & 6,7 & 146,0 & 0,006 & 1,5 \\
\hline & P41 & 23,9 & 6,5 & 6,9 & 168,0 & 0,006 & 0,5 \\
\hline & P14S & 24,1 & 6,4 & 7,2 & 124,0 & 0,006 & 1,8 \\
\hline & $\mathrm{P} 14 \mathrm{~F}$ & 23,7 & 6,4 & 6,5 & 138,0 & 0,005 & - \\
\hline \multicolumn{2}{|c|}{ Média } & 24,1 & 6,4 & 6,8 & 144,0 & 0,006 & - \\
\hline \multirow{4}{*}{ Abril } & Cab & 21,9 & 6,2 & 4,6 & 282,0 & 0,016 & 1,5 \\
\hline & P41 & 22,5 & 6,5 & 5,1 & 327,0 & 0,026 & 0,5 \\
\hline & P14S & 24,8 & 6,5 & 5,4 & 147,0 & 0,005 & 1,6 \\
\hline & $\mathrm{P} 14 \mathrm{~F}$ & 22,5 & 6,4 & 4,0 & 176,0 & 0,006 & - \\
\hline \multicolumn{2}{|c|}{ Média } & 22,9 & 6,4 & 4,7 & 233,0 & 0,013 & - \\
\hline \multirow{4}{*}{ Julho } & (Cab) & 15 & 6,2 & 6,2 & 339,0 & 0,004 & 1,5 \\
\hline & (P41) & 18,2 & 6,2 & 7,2 & 513,0 & 0,002 & 0,5 \\
\hline & (P14S) & 17,2 & 6,3 & 6,2 & 409,0 & 0,002 & 3,5 \\
\hline & (P14F) & 16,1 & 6,2 & 6,2 & 383,0 & 0,002 & - \\
\hline \multicolumn{2}{|c|}{ Média } & 16,3 & 6,2 & 6,4 & 411,0 & 0,003 & - \\
\hline \multirow{4}{*}{ Outubro } & Cab & 27,0 & 6,7 & 8,2 & 126,4 & 0,000 & 1,5 \\
\hline & P41 & 26,0 & 6,7 & 8,7 & 197,6 & 0,004 & 0,5 \\
\hline & P14S & 25,0 & 6,5 & 8,6 & 252,0 & 0,007 & 3,5 \\
\hline & $\mathrm{P} 14 \mathrm{~F}$ & $x$ & $x$ & $x$ & $x$ & $\mathbf{x}$ & - \\
\hline \multicolumn{2}{|c|}{ Média } & 26,0 & 6,6 & 8,5 & 192,0 & 0,004 & - \\
\hline \multirow{4}{*}{ Fevereiro } & (Cab) & 21,0 & 5,7 & 6,8 & 261,7 & 0,027 & 1,5 \\
\hline & (P41) & 26,9 & 6,1 & 7,3 & 307,7 & 0,000 & 0,5 \\
\hline & (P14S) & 25,1 & 5,4 & 7,3 & 449,6 & 0,014 & 3,5 \\
\hline & (P14F) & 21,8 & 5,3 & 7,3 & 423,0 & 0,015 & - \\
\hline \multicolumn{2}{|c|}{ Média } & 23,7 & 5,6 & 7,2 & 360,5 & 0,014 & - \\
\hline \multicolumn{2}{|c|}{$\begin{array}{c}\text { CONAMA, res. } \\
357 / 2005 \\
\text { (Classe II) }\end{array}$} & - & 6,0 a 9,0 & $>5 \mathrm{mg} \cdot \mathrm{L}^{-1}$ & - & $500 \mathrm{mg} \cdot \mathrm{L}^{-1}$ & - \\
\hline
\end{tabular}

$\mathrm{N}=43$.

- não há limite

$X=$ não avaliado

Valores Zero = abaixo do limite de detecção do método utilizado 
Tabela 4. Valores de concentração de fósforo, de dureza, de fluoreto, de manganês, de zinco, de sulfato, de urânio e de tório em amostras de água na Represa das Antas, coletadas em diferentes pontos de amostragem.

\begin{tabular}{|c|c|c|c|c|c|c|c|c|c|}
\hline \multicolumn{10}{|c|}{$\mathrm{mg} / \mathrm{L}$} \\
\hline Meses & Pontos & Dureza & P total & $\mathrm{F}^{-}$ & Mn & $\mathrm{Zn}$ & $\mathrm{SO}_{4}{ }^{-2}$ & $U$ & Th \\
\hline \multirow{5}{*}{ Janeiro } & Cab & 52,0 & $\mathrm{X}$ & 1,51 & 1,54 & $<0,20$ & 84,40 & $<0,06$ & 0,03 \\
\hline & P41 & 53,1 & $X$ & 1,53 & 1,54 & $<0,20$ & 79,90 & $<0,05$ & $<0,02$ \\
\hline & P14S & 50,2 & $\mathrm{X}$ & 1,53 & 15,10 & $<0,20$ & 77,80 & $<0,05$ & $<0,02$ \\
\hline & $\mathrm{P} 14 \mathrm{~F}$ & 51,8 & $X$ & 1,56 & 1,53 & $<0,20$ & 81,00 & $<0,05$ & $<0,02$ \\
\hline & MÉDIA & 51,7 & - & 1,50 & 1,53 & - & 80,77 & - & - \\
\hline \multirow{4}{*}{ Abril } & Cab & 3,0 & $<0,01$ & 0,50 & $<0,5$ & $<0,20$ & 2,00 & 0,11 & $<0,05$ \\
\hline & P41 & 5,4 & $<0,01$ & 0,50 & $<0,5$ & $<0,20$ & 2,00 & 0,11 & $<0,05$ \\
\hline & P14S & 40,0 & $<0,01$ & 8,50 & 0,59 & $<0,20$ & 34,50 & $<0,05$ & $<0,05$ \\
\hline & P14F & 59,0 & $<0,01$ & 18,00 & 0,66 & $<0,20$ & 50,90 & $<0,05$ & $<0,05$ \\
\hline & MÉDIA & 26,8 & - & 6,80 & - & - & 22,35 & - & - \\
\hline \multirow{5}{*}{ Julho } & Cab & 201,6 & $<0,01$ & $X$ & 1,26 & $<0,04$ & 195,00 & $<0,05$ & $<0,05$ \\
\hline & P41 & 293,0 & $<0,01$ & $X$ & 2,40 & 0,21 & 278,70 & $<0,05$ & $<0,05$ \\
\hline & P14S & 237,2 & $<0,01$ & $X$ & 1,68 & $<0,1$ & 215,90 & $<0,05$ & $<0,05$ \\
\hline & $\mathrm{P} 14 \mathrm{~F}$ & 224,4 & $<0,01$ & $\mathrm{X}$ & 1,50 & $<0,1$ & 212,50 & $<0,05$ & 0,06 \\
\hline & MÉDIA & 239,0 & - & - & 1,71 & - & 226,00 & - & - \\
\hline \multirow{5}{*}{ Outubro } & Cab & 43,1 & $<0,01$ & $\mathrm{X}$ & 0,54 & $<0,05$ & 39,20 & 0,08 & $<0,05$ \\
\hline & P41 & 65,7 & $<0,01$ & $X$ & 0,68 & $<0,05$ & 62,70 & 0,06 & $<0,05$ \\
\hline & P14S & 100,2 & $<0,01$ & $\mathrm{X}$ & 0,98 & $<0,05$ & 110,30 & 0,06 & $<0,05$ \\
\hline & P14F & $X$ & $X$ & $X$ & $X$ & $X$ & $x$ & $X$ & $x$ \\
\hline & MÉDIA & 69,6 & - & - & 0,73 & - & 70,73 & 0,06 & - \\
\hline \multirow{5}{*}{ Fevereiro } & Cab & 7,8 & $<0,01$ & 0,60 & 0,55 & $<0,02$ & 3,65 & $<0,05$ & $<0,05$ \\
\hline & P41 & 448,8 & $<0,01$ & 13,40 & 18,2 & 2,03 & 412,30 & $<0,05$ & $<0,05$ \\
\hline & P14S & 47,1 & $<0,01$ & 2,34 & 2,54 & $<0,02$ & 45,20 & $<0,05$ & $<0,05$ \\
\hline & $\mathrm{P} 14 \mathrm{~F}$ & 61,0 & $<0,01$ & 2,98 & 2,90 & $<0,02$ & 60,90 & $<0,05$ & $<0,05$ \\
\hline & MÉDIA & 141,2 & - & 4,80 & 6,05 & & 130,50 & - & - \\
\hline CONAMA & $\begin{array}{c}\text { Res.357/05 } \\
\text { (Classe II) }\end{array}$ & - & 0,050 & 1,4 & 0,1 & 0,18 & 250 & 0,02 & - \\
\hline $\begin{array}{l}\text { Ofício } \\
\text { CNEN }\end{array}$ & $\begin{array}{c}n^{\circ} 50 / S L C \\
06 / 1997\end{array}$ & - & - & - & - & - & - & 0,02 & 0,02 \\
\hline
\end{tabular}

Valores Zero = abaixo do limite de detecção do método utilizado

\subsection{Clorofila e Feofitina}

Para os valores de clorofila a, o maior valor médio detectado ocorreu em amostras de água coletadas no mês de fevereiro $\left(0,155 \mu \mathrm{g} \cdot \mathrm{L}^{-1}\right)$ e o menor valor 
médio foi registrado naquelas coletadas em outubro $\left(0 \mu \mathrm{g} \cdot \mathrm{L}^{-1}\right)$, como mostra a Tabela 5. Em janeiro, abril e julho foram detectados os maiores valores de clorofila a em amostras de água coletadas no ponto P41. Somente no mês de fevereiro, o maior valor de cloforila a foi detectado em amostra de água procedente do ponto P14S, seguido do ponto Cab (Tabela 5). Os valores de clorofila a detectados em amostras de água procedentes da Represa das Antas, em todo o período de estudo, estiveram dentro dos limites estabelecidos pela Resolução 357 do Conama (CONAMA, 2005).

O maior valor obtido para clorofila $b$ foi registrado em amostra de água coletada no mês de julho no ponto $\operatorname{Cab}\left(0,86 \mu \mathrm{g} \cdot \mathrm{L}^{-1}\right)$. Espacialmente, o valor médio de clorofila $b$ obtido para o ponto P41 $\left(0,0025 \mu \mathrm{g} \cdot \mathrm{L}^{-1}\right)$ e para o ponto P14F $\left(0,00 \mu \mathrm{g} \cdot \mathrm{L}^{-1}\right)$ foi significativamente menor $(\mathrm{P}<0,05)$ do que $\mathrm{o}$ valor médio obtido para o ponto $\operatorname{Cab}\left(0,19 \mu \mathrm{g} \cdot \mathrm{L}^{-1}\right)$.

Em relação aos valores registrados para clorofila $c$ (Tabela 5), o maior valor médio detectado ocorreu em amostras de água coletadas no mês de julho (10,16 $\left.\mu \mathrm{g} \cdot \mathrm{L}^{-1}\right)$ enquanto que, o menor valor médio foi registrado em amostras coletadas no mês de janeiro $\left(0,035 \mu \mathrm{g} \cdot \mathrm{L}^{-1}\right)$.

Os valores médios de feofitina registrados para amostras de água da Represa das Antas variaram de $0 \mu \mathrm{g} \cdot \mathrm{L}^{-1}$ (janeiro) a $0,009 \mu \mathrm{g} \cdot \mathrm{L}^{-1}$ (julho), como mostra a Tabela 5. 
Tabela 5. Valores médios de Clorofila $a, b, c$ e de Feofitina em $\mu \mathrm{g} \cdot \mathrm{L}^{-1} \mathrm{em}$ amostras de água da Represa das Antas

\begin{tabular}{|c|c|c|c|c|c|}
\hline Meses & Pontos & Clorofila a & Clorofila $b$ & Clorofila $c$ & Feofitina \\
\hline \multirow{4}{*}{ Janeiro } & Cab & 0,0000 & 0,0000 & 0,0000 & 0,0000 \\
\hline & P41 & 0,2990 & 0,0010 & 0,0000 & 0,0000 \\
\hline & P14S & 0,0000 & 0,0040 & 0,1380 & 0,0000 \\
\hline & $\mathrm{P} 14 \mathrm{~F}$ & 0,0000 & 0,0000 & 0,0000 & 0,0000 \\
\hline & Média & 0,0750 & 0,0010 & 0,0350 & 0,0000 \\
\hline \multirow{4}{*}{ Abril } & Cab & 0,0000 & 0,0000 & 0,0440 & 0,0000 \\
\hline & P41 & 0,2090 & 0,0000 & 0,2710 & 0,0001 \\
\hline & P14S & 0,0000 & 0,0000 & 0,2550 & 0,0001 \\
\hline & P14F & 0,0000 & 0,0000 & 0,2050 & 0,0002 \\
\hline & Média & 0,0520 & 0,0000 & 0,1940 & 0,0001 \\
\hline \multirow{4}{*}{ Julho } & Cab & 0,0930 & 0,8600 & 19,310 & 0,0100 \\
\hline & P41 & 0,0187 & 0,0000 & 18,610 & 0,0200 \\
\hline & P14S & 0,0000 & 0,0000 & 2,6400 & 0,0000 \\
\hline & P14F & 0,0000 & 0,0000 & 0,1000 & 0,0000 \\
\hline \multirow{5}{*}{ Outubro } & Média & 0,0280 & 0,2140 & 10,164 & 0,0090 \\
\hline & Cab & 0,0000 & 0,0000 & 3,5520 & 0,0005 \\
\hline & P41 & 0,0000 & 0,0050 & 0,0000 & 0,0004 \\
\hline & P14S & 0,0000 & 0,0000 & 2,8930 & 0,0005 \\
\hline & ${ }^{*} \mathrm{P} 14 \mathrm{~F}$ & $x$ & $x$ & $X$ & $x$ \\
\hline \multirow{5}{*}{ Fevereiro } & Média & 0,0000 & 0,0016 & 2,1500 & 0,0005 \\
\hline & Cab & 0,1196 & 0,0000 & 0,0000 & 0,0000 \\
\hline & P41 & 0,0000 & 0,0110 & 0,0000 & 0,0000 \\
\hline & P14S & 0,5024 & 0,0030 & 0,4810 & 0,0001 \\
\hline & P14F & 0,0000 & 0,0000 & 0,0000 & 0,0000 \\
\hline & Média & 0,1550 & 0,0030 & 0,1200 & 0,0000 \\
\hline $\begin{array}{c}\text { CONAMA } \\
\text { Res. } \\
357 / 2005\end{array}$ & & $\leq \mathbf{3 0} \mu \mathrm{g} / \mathrm{L}$ & , & - & - \\
\hline $\begin{array}{l}N=43 \\
\text { - não há lim } \\
X=\text { não ava }\end{array}$ & & & & & \\
\hline
\end{tabular}

\section{4 Índice de Estado Trófico}

De acordo com os resultados obtidos para o índice de estado trófico, calculado utilizando valores de clorofila $a$, bem como os valores de transparência da água,a Represa das Antas foi classificada como oligotrófica, durante todo o período de amostragem (Tabela 6). 
Tabela 6. Índice de Estado Trófico na Represa das Antas

\begin{tabular}{|c|c|c|}
\hline & IET (Cl a) & IET (TraS) \\
\hline \multirow[t]{2}{*}{ Total } & $-5,00$ & 35,85 \\
\hline & Oligotrófica & Oligotrófica \\
\hline Meses & IET (Cl a) & IET (TraS) \\
\hline Janeiro & 4,55 & 37,12 \\
\hline Abril & 0,97 & 38,90 \\
\hline Julho & $-5,33$ & 34,90 \\
\hline Outubro & 0,00 & 42,00 \\
\hline \multirow[t]{2}{*}{ Fevereiro } & 11,90 & 34,90 \\
\hline & Oligotrófica & Oligotrófica \\
\hline
\end{tabular}

$\mathrm{N}=20$.

\subsection{Variáveis Biológicas}

3.5.1 Tipos nutricionais, classes e gêneros dos protozoários ciliados e do dinoflagelado Peridinium sp.

$\mathrm{Na}$ Represa das Antas foram identificados oito gêneros de protozoários ciliados (Campanella umbellaria, Vorticella sp., Urotricha sp., Enchelys sp., Mesodinium sp., Monodinium sp. Paradileptus elephantinus, Strombidium sp.) e um gênero de dinoflagelado (Peridinium sp.), ao longo de todo o período avaliado. Estes gêneros foram classificados como pertencentes às Classes Peritricha (Campanella umbellaria e Vorticella sp.), Prostomatida (Urotricha sp.), Gymnostomatida (Enchelys sp., Mesodinium sp., Monodinium sp. e Paradileptus elephantinus), Oligotricha (Strombidium sp.) e Phytomastigophora (Peridinium sp.) como mostram as Tabelas $7 \mathrm{a}$ e $7 \mathrm{~b}$.

Quanto às categorias tróficas (tipos nutricionais) relacionadas aos valores médios de biomassa dos protozoários ciliados observados neste corpo aquático nos diferentes períodos de amostragem, a Represa das Antas apresentou a predominância dos bacterívoros/algívoros (bac/alg) nos meses de janeiro (82\%) e abril $(65 \%)$, enquanto que, nos meses de julho (58\%), outubro (95\%) e fevereiro (51\%), o grupo nutricional predominante foi o que apresenta preferência alimentar por diatomáceas, algas e bactérias (ki/alg/bac) (Tabela 7a). 
Sazonalmente, o dinoflagelado Peridinium sp. classificado como um organismo mixotrófico, inserido na categoria trófica dos autótrofos/bacterívoros (auto/bac), predominou, em relação ao valor médio total de biomassa registrado ao longo do estudo, em amostras de água coletadas no mês de fevereiro (51,66\%), como mostra a Tabela $7 a$.

Por outro lado, em relação às categorias tróficas (tipos nutricionais) relacionadas aos valores médios de densidade dos protozoários ciliados, observados neste corpo aquático nos diferentes períodos de amostragem, a Represa das Antas apresentou a predominância dos omnívoros (O) no mês de janeiro $(71 \%)$, no mês de abril predominaram os bac/alg $(67 \%)$, nos meses de julho/06 e fevereiro/07 foi verificada a predominância dos ki/alg/bac (73\% e 76\%, respectivamente). Somente no mês de outubro a dominância dos tipos nutricionais foi compartilhada entre os $\mathrm{O}(37 \%)$, ki/alg/bac (36\%) e os bac/flag $(21 \%)$, como mostra a Tabela 7b.

Sazonalmente, o dinoflagelado Peridinium sp. (tipo nutricional autótrofos/bacterívoros (auto/bac)), predominou, em relação ao valor médio total de densidade registrado ao longo do estudo, em amostras de água coletadas no mês de fevereiro $(37,70 \%)$, como mostra a Tabela $7 \mathrm{~b}$.

$\mathrm{Na}$ Represa das Antas, ao longo de todo o período de estudo avaliado foi registrada a predominância do tipo nutricional ki/alg/bac em relação ao valor percentual médio de biomassa $(82,3 \%)$, bem como para o valor percentual médio de densidade (48\%). As demais categorias tróficas avaliadas durante o período de estudo para os valores percentuais médios de biomassa foram os omnívoros $(9,5 \%)$, bac/alg $(6,7 \%)$, bac/flag $(1,2 \%)$, bem como o R-predador $(0,2 \%)$. Para os valores percentuais médios de densidade dos protozoários ciliados coletados em amostras de água provenientes da Represa das Antas foram os Omnívoros (32\%), bac/alg $(12 \%)$, bac/flag $(7 \%)$, bem como o R-predador $(1 \%)$ como mostram as Figuras 2 e 3 . 
Tabela 7. Percentagem dos tipos nutricionais de protozoários ciliados e do dinoflagelado Peridinium sp. em amostras de água da Represa das Antas

a) Porcentagem calculada baseando-se nos valores de biomassa obtidos para os protozoários ciliados e o dinoflagelado Peridinium sp. em amostras de água da Represa das Antas

\begin{tabular}{|c|c|c|c|c|c|c|c|}
\hline \multirow{2}{*}{$\begin{array}{c}\text { Tipos } \\
\text { Nutricionais }\end{array}$} & \multirow[t]{2}{*}{ Classes } & \multirow[t]{2}{*}{ Gêneros } & \multicolumn{5}{|c|}{ BIOMASSA (\%) } \\
\hline & & & Jan & Abr & Jul & Out & Fev \\
\hline${ }^{*} \mathrm{Bac} / \mathrm{Alg}$ & Peritrichia & $\begin{array}{c}\text { Campanella } \\
\text { umbellaria } \\
\text { Vorticella sp. }\end{array}$ & 82 & 65 & 0 & 0,1 & 34 \\
\hline${ }^{*}$ Bac/Flag & Prostomatida & Urotricha sp. & 3 & 0 & 0 & 1,4 & 0 \\
\hline *Omnívoro & Gymnostomatida & $\begin{array}{l}\text { Enchelys sp. } \\
\text { Mesodinium sp. } \\
\text { Paradileptus } \\
\text { elephantinus }\end{array}$ & 7 & 25 & 42 & 3,6 & 15 \\
\hline${ }^{*} \mathrm{Ki} / \mathrm{Alg} / \mathrm{Bac}$ & Oligotricha & Strombidium sp. & 8 & 9 & 58 & 94,7 & 51 \\
\hline${ }^{*} \mathrm{R}$ predador & Gymnostomatida & Monodinium sp. & 0 & 1 & 0 & 0,3 & 0 \\
\hline${ }^{* *}$ Auto/bac & Phytomastigophora & Peridinium sp. & 2,83 & 2,62 & 5,59 & 37,30 & 51,66 \\
\hline
\end{tabular}

Tabela 7. Percentagem dos tipos nutricionais de protozoários ciliados e do dinoflagelado Peridinium sp. em amostras de água da Represa das Antas

b) Porcentagem calcula baseando-se nos valores de densidade obtidos para os protozoários ciliados e o dinoflagelado Peridinium sp. em amostras de água da Represa das Antas

\begin{tabular}{|c|c|c|c|c|c|c|c|}
\hline \multirow[t]{2}{*}{$\begin{array}{c}\text { Tipos } \\
\text { Nutricionais }\end{array}$} & \multirow[t]{2}{*}{ Classes } & \multirow[t]{2}{*}{ Gêneros } & \multicolumn{5}{|c|}{ DENSIDADE (\%) } \\
\hline & & & Jan & Abr & Jul & Out & Fev \\
\hline Bac/Alg & Peritrichia & $\begin{array}{c}\text { Campanella } \\
\text { umbellaria } \\
\text { Vorticella sp. }\end{array}$ & 9 & 67 & 0 & 3 & 4 \\
\hline Bac/Flag & Prostomatida & Urotricha sp. & 11 & 0 & 0 & 21 & 0 \\
\hline Omnívoro & Gymnostomatida & $\begin{array}{l}\text { Enchelys sp. } \\
\text { Mesodinium sp. } \\
\text { Paradileptus } \\
\text { elephantinus }\end{array}$ & 71 & 17 & 27 & 37 & 20 \\
\hline Ki/Alg/Bac & Oligotricha & Strombidium sp. & 9 & 14 & 73 & 36 & 76 \\
\hline R predador & Gymnostomatida & Monodinium sp. & 0 & 2 & 0 & 3 & 0 \\
\hline
\end{tabular}

\begin{tabular}{l|l|l|l|l|l|l|l}
\hline${ }^{* *}$ Auto/bac & Phytomastigophora & Peridinium sp. & 2,86 & 2,65 & 20,70 & 36,09 & 37,70 \\
\hline $\mathrm{N}=43$.
\end{tabular}




\section{Biomassa Média Total}

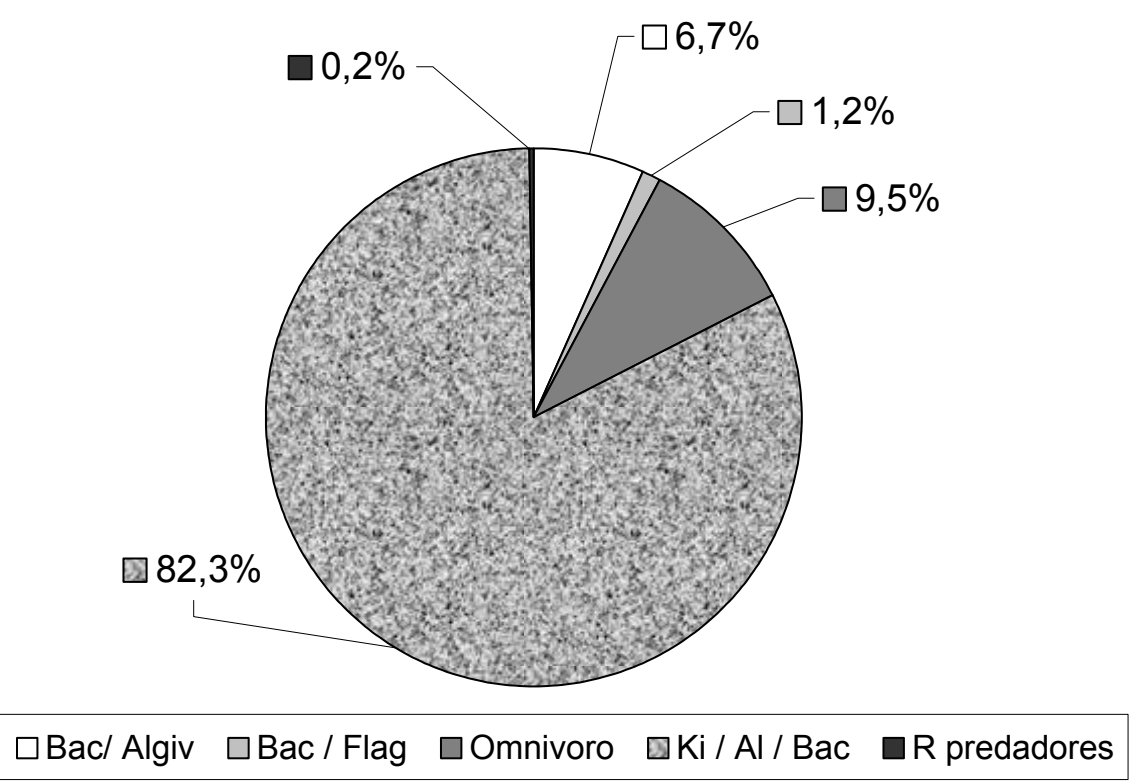

Figura 2. Valor percentual médio de biomassa dos tipos nutricionais dos protozoários ciliados em amostras de água da Represa das Antas.

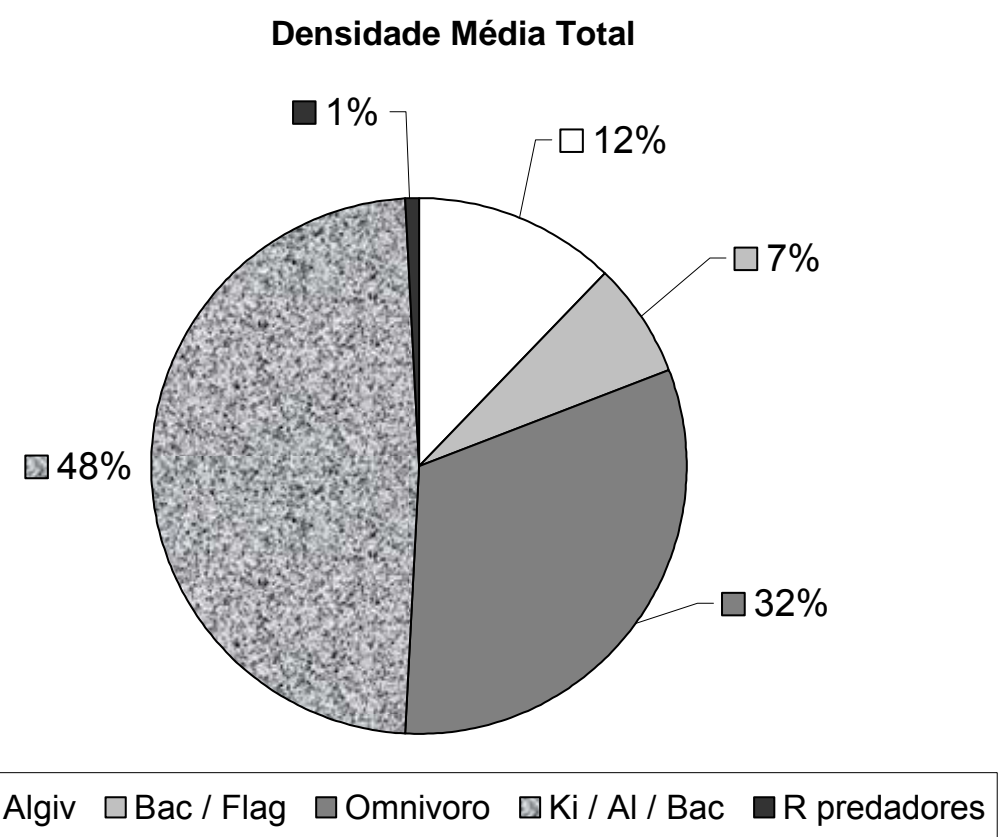

Figura 3. Valor percentual médio de densidade dos tipos nutricionais dos protozoários ciliados em amostras de água da Represa das Antas. 
3.5.2 Variação Sazonal e Espacial dos protozoários ciliados, do dinoflagelado Peridinium sp., do bacterioplâncton e da biomassa fitoplanctônica na Represa das Antas

Dentre as Classes de protozoários ciliados e a Classe do dinoflagelado Peridinium sp. detectadas em amostras de água da Represa das Antas, os organismos pertencentes às Classes Oligotricha e Phytomastigophora foram os dominantes quando considerados os valores médios totais de biomassa e densidade registados ao longo do período de estudo, como mostra a Tabela 8.

Tabela 8. Valores médios totais de biomassa e de densidade para as Classes dos protozoários ciliados e do dinoflagelado Peridinium sp., em amostras de água da Represa das Antas, ao longo do período avaliado.

\begin{tabular}{c|c|c}
\hline Classes & Biomassa $\left(\mu \mathbf{g ~ C ~ . ~ L ~}{ }^{-1}\right)$ & Densidade (ind . $\mathbf{~}^{-1} \cdot \mathbf{1 0}$ ) \\
\hline Peritrichas & 0,214 & 0,096 \\
\hline Oligotrichida & 2,629 & 0,408 \\
\hline Gymnostomatida & 0,310 & 0,168 \\
\hline Prostomatida & 0,038 & 0,058 \\
\hline Phytomastigophora & 5,042 & 73,480 \\
$\mathrm{~N}=43$ &
\end{tabular}

De acordo com os resultados obtidos para protozoários ciliados observados em amostras de agua da Represa das Antas, foram registrados valores de densidade variando entre $0,005.10^{3}$ a $0,010.10^{3}$ ind. $\mathrm{L}^{-1}$ em janeiro, de $0,010.10^{3}$ à $0,019.10^{3}$ ind. $L^{-1}$ em abril, de $0,003.10^{3}$ a $0,027.10^{3}$ ind. $L^{-1}$ no mês de julho, de $0,006.10^{3}$ a $0,087.10^{3}$ ind. $L^{-1}$ durante o mês de outubro e de $0,003.10^{3}$ a $0,089.10^{3}$ ind. $L^{-1}$ em fevereiro. De um total de cinco amostragens realizadas no presente estudo, em duas delas, os maiores valores de densidade para os protozoários ciliados foram verificados em amostras de água coletadas no ponto Cab nos meses de outubro $\left(0,087.10^{3}\right.$ ind. $\left.L^{-1}\right)$ e fevereiro $\left(0,089.10^{3}\right.$ ind. $\left.L^{-1}\right)$, enquanto que, em três delas, os menores valores foram verificados em amostras do ponto P41,ou seja, nos meses de julho $\left(0,003 \cdot 10^{3}\right.$ ind. $\left.L^{-1}\right)$, outubro $\left(0,006.10^{3}\right.$ ind. $\left.\mathrm{L}^{-1}\right)$ e fevereiro $\left(0,003 \cdot 10^{3}\right.$ ind. $\left.\mathrm{L}^{-1}\right)$, como mostra a Figura $4 \mathrm{a}, 4 \mathrm{~b}, 4 \mathrm{c}$ e $4 \mathrm{~d}$. 
O bacterioplâncton presente em amostras de água da Represa das Antas apresentou valores de densidade variando entre $1,0.10^{9}$ à $5,0.10^{9}$ ind. $L^{-1}$ para janeiro, de $5,0.10^{9}$ à $8,0.10^{9}$ ind. $L^{-1}$ para abril, de $1,0.10^{9}$ à $7,0.10^{9}$ ind. $L^{-1}$ para julho, de $2,0.10^{9}$ à $9,0.10^{9}$ ind.L-1 para outubro e de $1,0.10^{9}$ à $3,0.10^{9}$ ind..$^{-1}$ para o mês de fevereiro. Os maiores valores de densidade registrados para a variavel bacterioplâncton foram verificados em amostras de água do ponto P41 nos meses de abril $\left(8.10^{9}\right.$ ind. $\left.L^{-1}\right)$ e outubro $\left(9.10^{9}\right.$ ind. $\left.L^{-1}\right)$, enquanto que, os menores valores foram registrados em amostras de água coletadas no ponto P14S e P14F $\left(1,1.10^{9}\right.$ ind. $\left.\mathrm{L}^{-1}\right)$ no mês de fevereiro, seguido do valor detectado em amostras de água do ponto P41 $\left(1,0.10^{9}\right.$ ind. $\left.L^{-1}\right)$ no mês de julho, como mostra a Figura $5 a, 5 b, 5 c$ e $5 d$.

Para o dinoflagelado Peridinium sp. observados em amostras de água da Represa das Antas foram verificados valores de densidade variando de $2,0.10^{3}$ à $3,97.10^{3}$ ind. $\mathrm{L}^{-1}$ em janeiro, de $0,69.10^{3}$ à $5,97.10^{3}$ ind. $\mathrm{L}^{-1}$ em abril, de $4,06 \cdot 10^{3}$ à $32,64.10^{3}$ ind. $\mathrm{L}^{-1}$ para o mês de julho, de $24,93 \cdot 10^{3}$ à $79,38 \cdot 10^{3}$ ind. $\mathrm{L}^{-1}$ durante o mês de outubro e de $20,03.10^{3}$ à $58,51 \cdot 10^{3}$ ind. $L^{-1}$ no mês de fevereiro. Os maiores valores de densidade foram observados em amostras de água procedentes do ponto Cab no mês de outubro $\left(79,38.10^{3}\right.$ ind. $\left.\mathrm{L}^{-1}\right)$ e os menores valores observados em amostras do ponto P14F no mês de abril $\left(0,69 \cdot 10^{3}\right.$ ind. $\left.\mathrm{L}^{-1}\right)$. $\mathrm{O}$ valor médio de densidade encontrado em amostras de água procedentes do ponto $\mathrm{Cab}$ foi significativamente maior $(P<0,05)$ do que 0 valor médio de densidade registrado no ponto $\mathrm{P} 14 \mathrm{~F}$, durante todo o estudo. Houve variação sazonal para os valores de densidade do Peridinium sp. registrados em amostras de água da Represa das Antas, uma vez que, no mês de outubro foi registrado o maior valor médio $(P<0,05)$ na densidade deste dinoflagelado, quando comparado aos resultados obtidos nos demais meses de amostragem. 
4a. Ponto Cab.
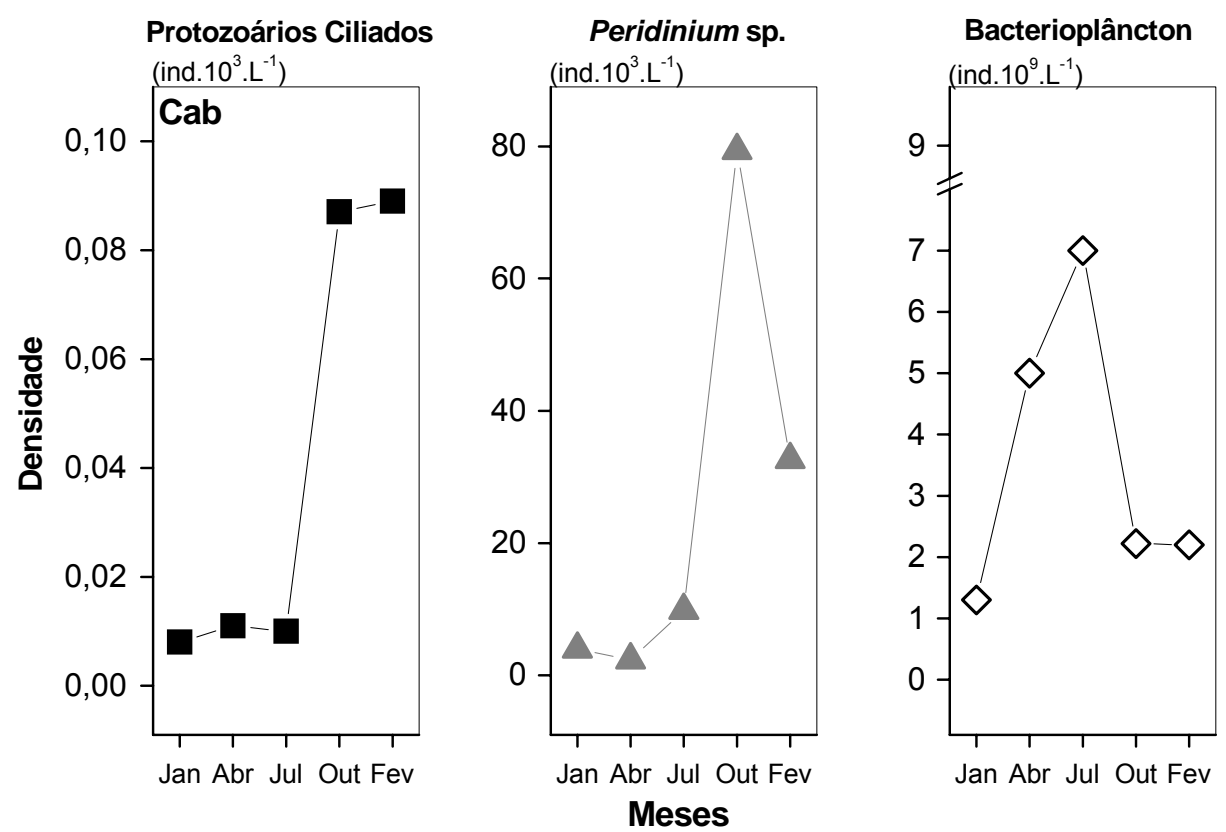

4b. Ponto P41.
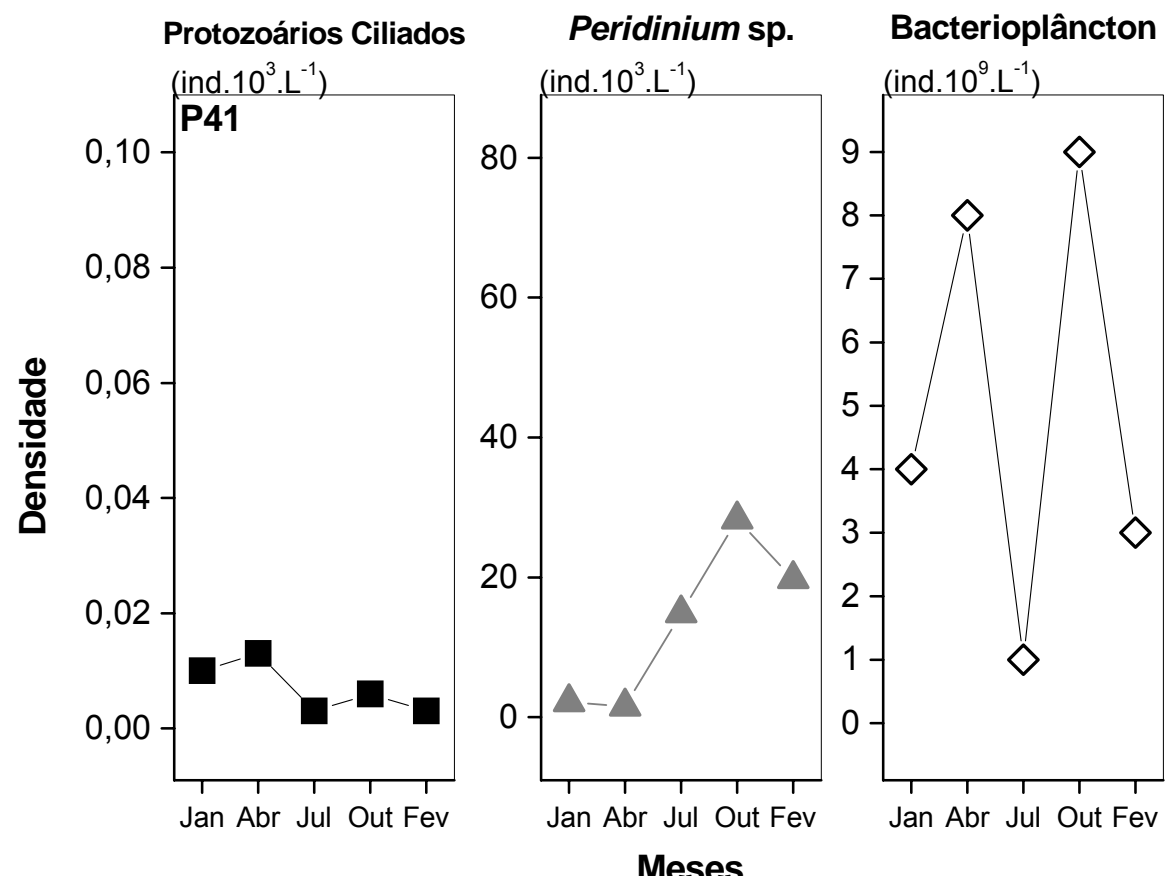

Meses

Figura 4(a/b). Densidade dos protozoários ciliados, do dinoflagelado Peridinium sp. e do bacterioplâncton em diferentes pontos de amostragem na Represa das Antas, ao longo do período avaliado. 
4c. Ponto P14S.
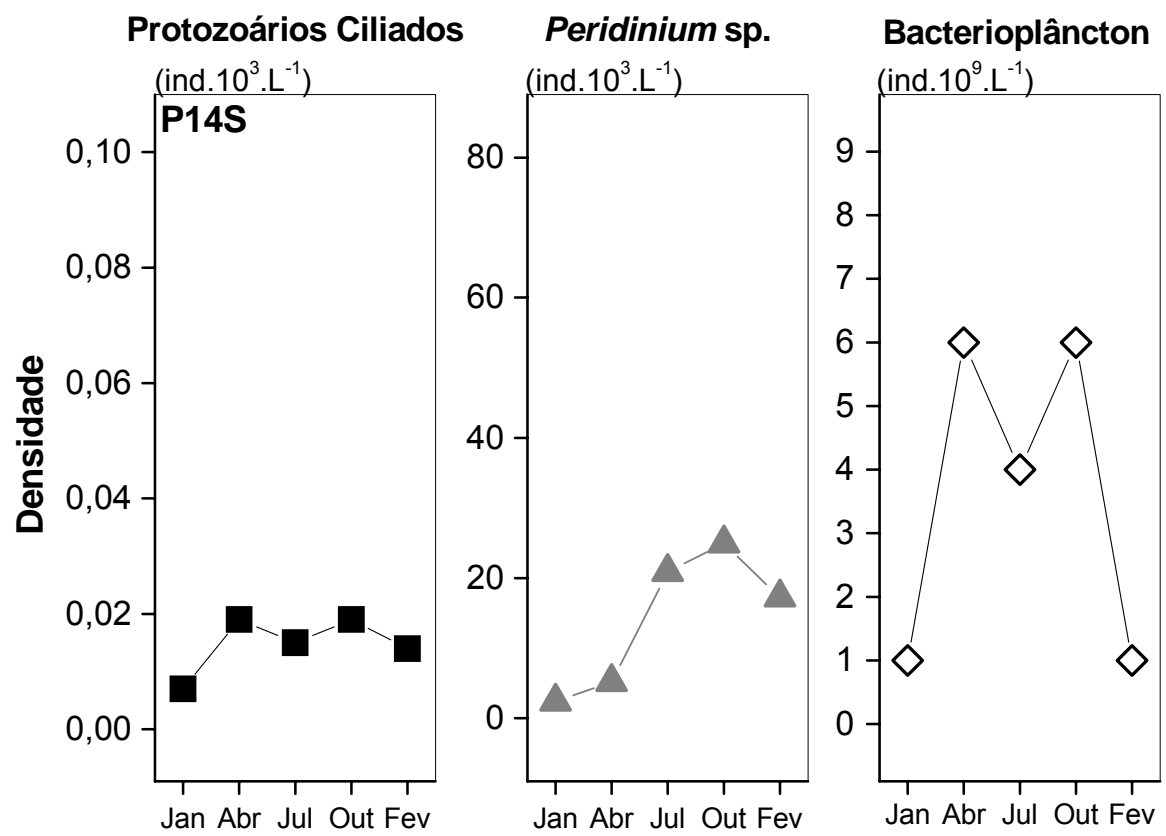

Meses

4d. Ponto P14F.

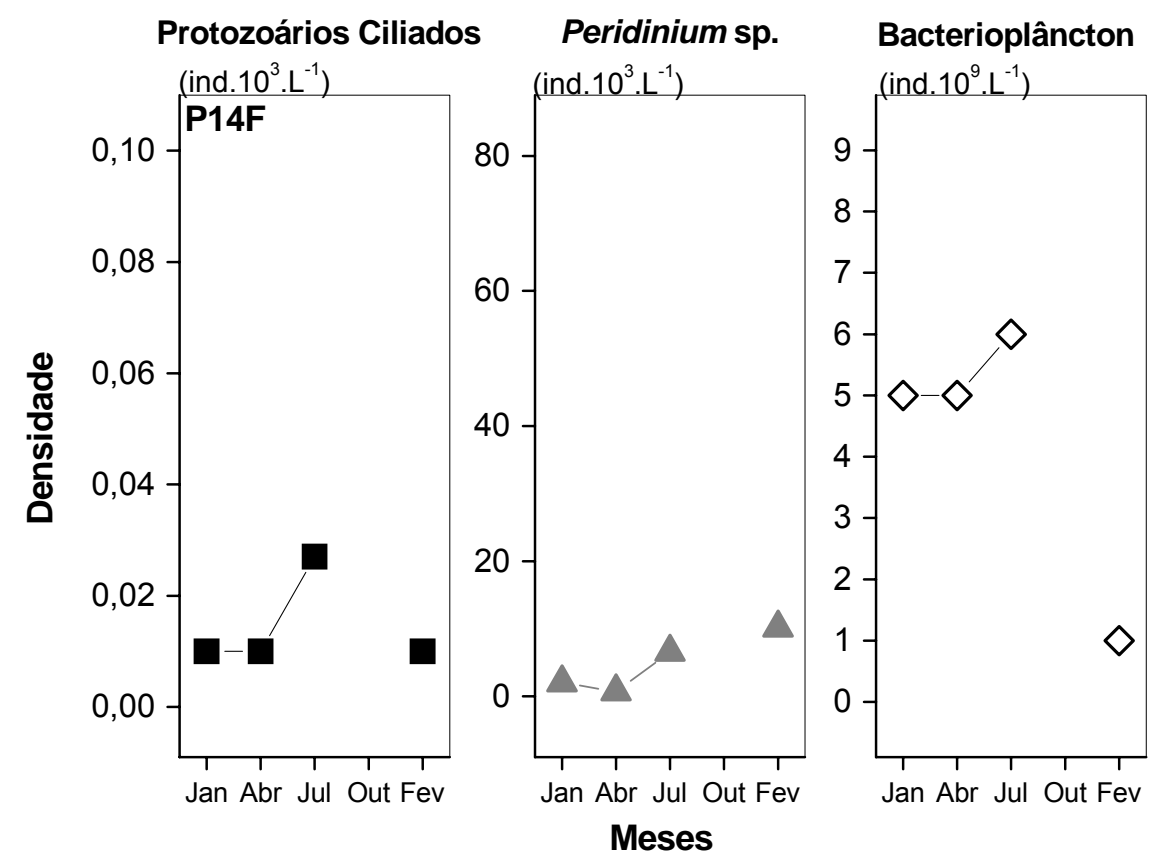

Figura 4(c/d). Densidade dos protozoários ciliados, do dinoflagelado Peridinium sp. e do bacterioplâncton em diferentes pontos de amostragem na Represa das Antas, ao longo do período avaliado. 
Em relação aos valores de biomassa determinados para os protozoários ciliados em amostras de água da Represa das Antas, foram observados valores variando entre $1,68 \mu \mathrm{g} \mathrm{C} \cdot 10^{-3} \cdot \mathrm{L}^{-1}$ a $58,77 \mu \mathrm{g} \mathrm{C} \cdot 10^{-3} \cdot \mathrm{L}^{-1}$ em janeiro, de $6,07 \mu \mathrm{g} \mathrm{C} \cdot 10^{-}$ ${ }^{3} . \mathrm{L}^{-1}$ à $23,52 \mu \mathrm{g} \mathrm{C} .10^{-3} \cdot \mathrm{L}^{-1}$ para o mês de abril, de $31,3 \mu \mathrm{g} \mathrm{C} \cdot 10^{-3} \cdot \mathrm{L}^{-1}$ à $75,94 \mu \mathrm{g}$ C. $10^{-3} \cdot \mathrm{L}^{-1}$ em julho, de $3,2 \mu \mathrm{g} C \cdot 10^{-3} \cdot \mathrm{L}^{-1}$ à $1213 \mu \mathrm{g} \mathrm{C} \cdot 10^{-3} \cdot \mathrm{L}^{-1}$ para o mês de outubro e de $0,8 \mu \mathrm{g} \mathrm{C} \cdot 10^{-3} \cdot \mathrm{L}^{-1}$ à $24,33 \mu \mathrm{g} \mathrm{C} \cdot 10^{-3} \cdot \mathrm{L}^{-1} \mathrm{em}$ fevereiro. Os dois maiores valores de biomassa para os protozoários ciliados foram registrados em amostras de água do ponto Cab no mês outubro $\left(1.213,0 \mu \mathrm{g} \mathrm{C} \cdot 10^{-3} \cdot \mathrm{L}^{-1}\right)$ e do ponto P14S no mês de julho $\left(75,94 \mu \mathrm{g} \mathrm{C} \cdot 10^{-3} \cdot \mathrm{L}^{-1}\right)$. Por outro lado, os dois menores valores médios de biomassa de protozoários ciliados foram verificados em amostras de água coletadas no ponto P14F $\left(1,68 \mu \mathrm{g} \mathrm{C} .10^{-3} \cdot \mathrm{L}^{-1}\right)$ e no ponto P14S $\left(2,78 \mu \mathrm{g} \mathrm{C} .10^{-3} \cdot \mathrm{L}^{-1}\right)$ em janeiro (Figuras $5 a, 5 b, 5 c$ e $5 d$ ).

Para o dinoflagelado Peridinium sp. foram verificados valores de biomassa variando entre $123,8 \mu \mathrm{g} \mathrm{C} \cdot 10^{-3} \cdot \mathrm{L}^{-1}$ à $264,4 \mu \mathrm{g} \mathrm{C} \cdot 10^{-3} \cdot \mathrm{L}^{-1} \mathrm{em}$ amostras de água coletadas em janeiro, de $42,7 \mu \mathrm{g} \mathrm{C} \cdot 10^{-3} \cdot \mathrm{L}^{-1}$ à $369,8 \mu \mathrm{g} \mathrm{C} \cdot 10^{-3} \cdot \mathrm{L}^{-1}$ no mês de abril, de $111,5 \mu \mathrm{g} \mathrm{C} \cdot 10^{-3} \cdot \mathrm{L}^{-1}$ à $2073,0 \mu \mathrm{g} \mathrm{C} .10^{-3} \cdot \mathrm{L}^{-1}$ em julho, de $1423,7 \mu \mathrm{g} \mathrm{C} \cdot 10^{-3} \cdot \mathrm{L}^{-1}$ à $6086,0 \mu \mathrm{g} \mathrm{C} .10^{-3} \cdot \mathrm{L}^{-1}$ para o mês de outubro e de $1423,7 \mu \mathrm{g} \mathrm{C} \cdot 10^{-3} \cdot \mathrm{L}^{-1}$ à $6531,5 \mu \mathrm{g}$ C. $10^{-3} \cdot \mathrm{L}^{-1}$ em fevereiro. Os dois maiores valores de biomassa de Peridinium sp. foram observados em amostras de água procedentes do ponto P14S no mês de fevereiro $\left(6531,5 \mu \mathrm{g} \mathrm{C} .10^{-3} . \mathrm{L}^{-1}\right)$ e do ponto Cab no mês de outubro $(6086,0 \mu \mathrm{g}$ C. $\left.10^{-3} \cdot \mathrm{L}^{-1}\right)$. Por outro lado, os dois menores valores de biomassa de Peridinium $\mathrm{sp}$. Foram detectados em amostras de água procedentes do ponto $\mathrm{P} 14 \mathrm{~F}$ em abril $\left(42,7 \mu \mathrm{g} \mathrm{C} .10^{-3} \cdot \mathrm{L}^{-1}\right)$ e do ponto P41 no mês de abril $\left(103,9 \mu \mathrm{g} \mathrm{C} .10^{-3} \cdot \mathrm{L}^{-1}\right)$ (Figuras $5 a, 5 b, 5 c$ e $5 d)$.

Em relação à biomassa fitoplanctônica, os resultados obtidos em amostras de água da Represa das Antas apresentaram valores variando entre $0 \mu \mathrm{g} \mathrm{C} \cdot 10^{-3} \cdot \mathrm{L}^{-1}$ à 20029,0 $\mu \mathrm{g} \mathrm{C} \cdot 10^{-3} \cdot \mathrm{L}^{-1}$ em janeiro, de $0 \mu \mathrm{g} \mathrm{C} \cdot 10^{-3} \cdot \mathrm{L}^{-1}$ à $14021,0 \mu \mathrm{g} C \cdot 10^{-3} \cdot \mathrm{L}^{-1}$ no mês de abril, de 0 à $6230,0 \mu \mathrm{g} \mathrm{C} \cdot 10^{-3} \cdot \mathrm{L}^{-1}$ para as amostras coletadas em julho. Durante o mês de outubro não houve registro de valores para a biomassa fitoplanctônica na Represa das Antas. Em fevereiro, foram detectados valores de biomassa fitoplanctônica em amostras de água variando de 0 à 33659,5 $\mu \mathrm{g} \mathrm{C.10^{- }}$ ${ }^{3} \cdot \mathrm{L}^{-1}$. Os dois maiores valores de biomassa fitoplanctônica registrados em pontos de amostragem avaliados neste estudo foram os seguintes: $33659,5 \mu \mathrm{g} \mathrm{C} .10^{-3} \cdot \mathrm{L}^{-1}$ 
em amostras de água coletadas no ponto P14S (fevereiro) e $20029,0 \mu \mathrm{g} \mathrm{C} .10^{-3} \cdot \mathrm{L}^{-1}$ no ponto P41 (janeiro). Os valores médios de biomassa fitoplanctônica registrados em amostras de água coletadas no ponto P41 foram significativamente maiores $(P<0,05)$ quando comparados aos resultados obtidos em amostras procedentes dos demais pontos avaliados (Figuras 5a, 5b, 5c e 5d). 
5a. Ponto Cab.
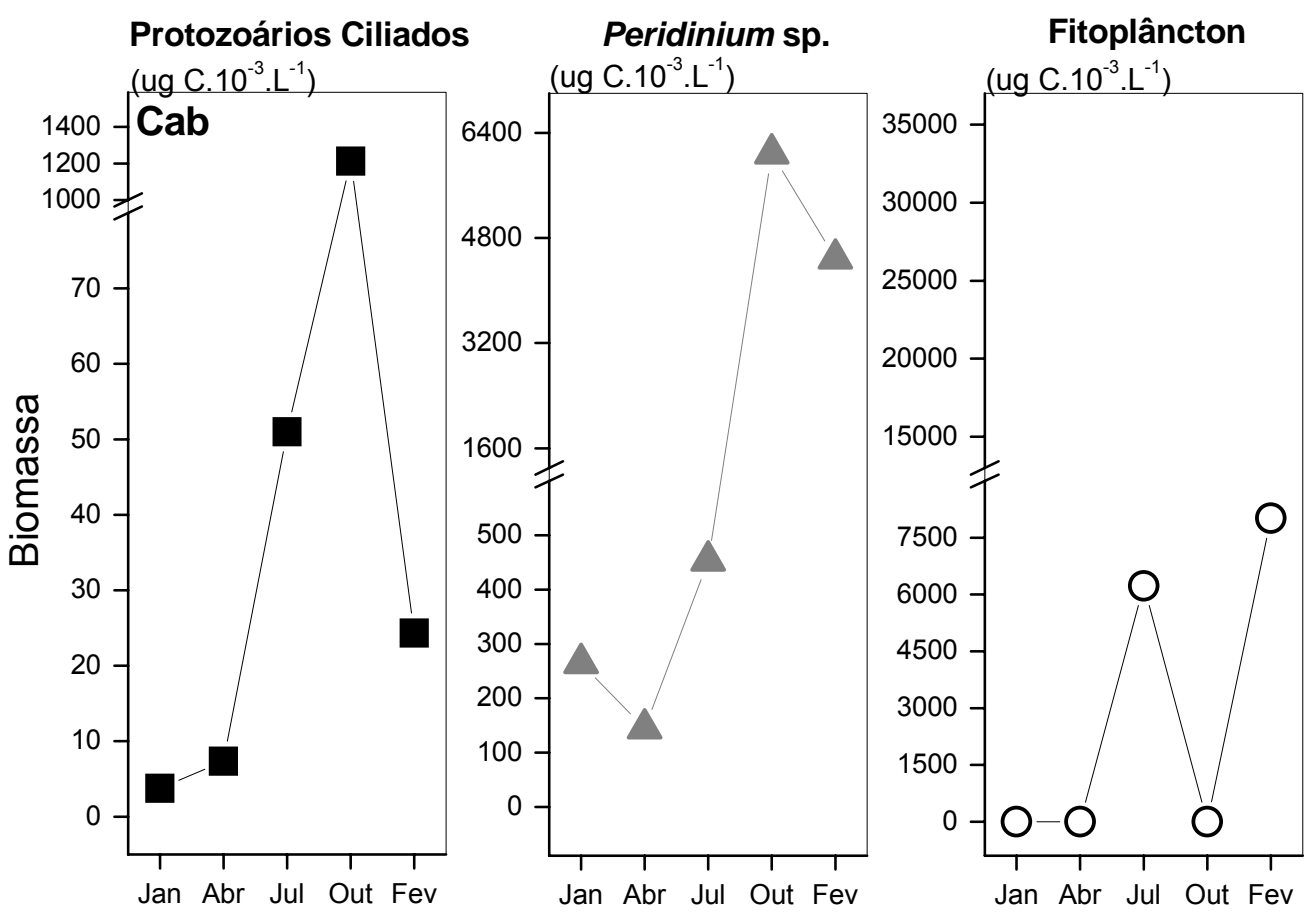

5b. Ponto P41.
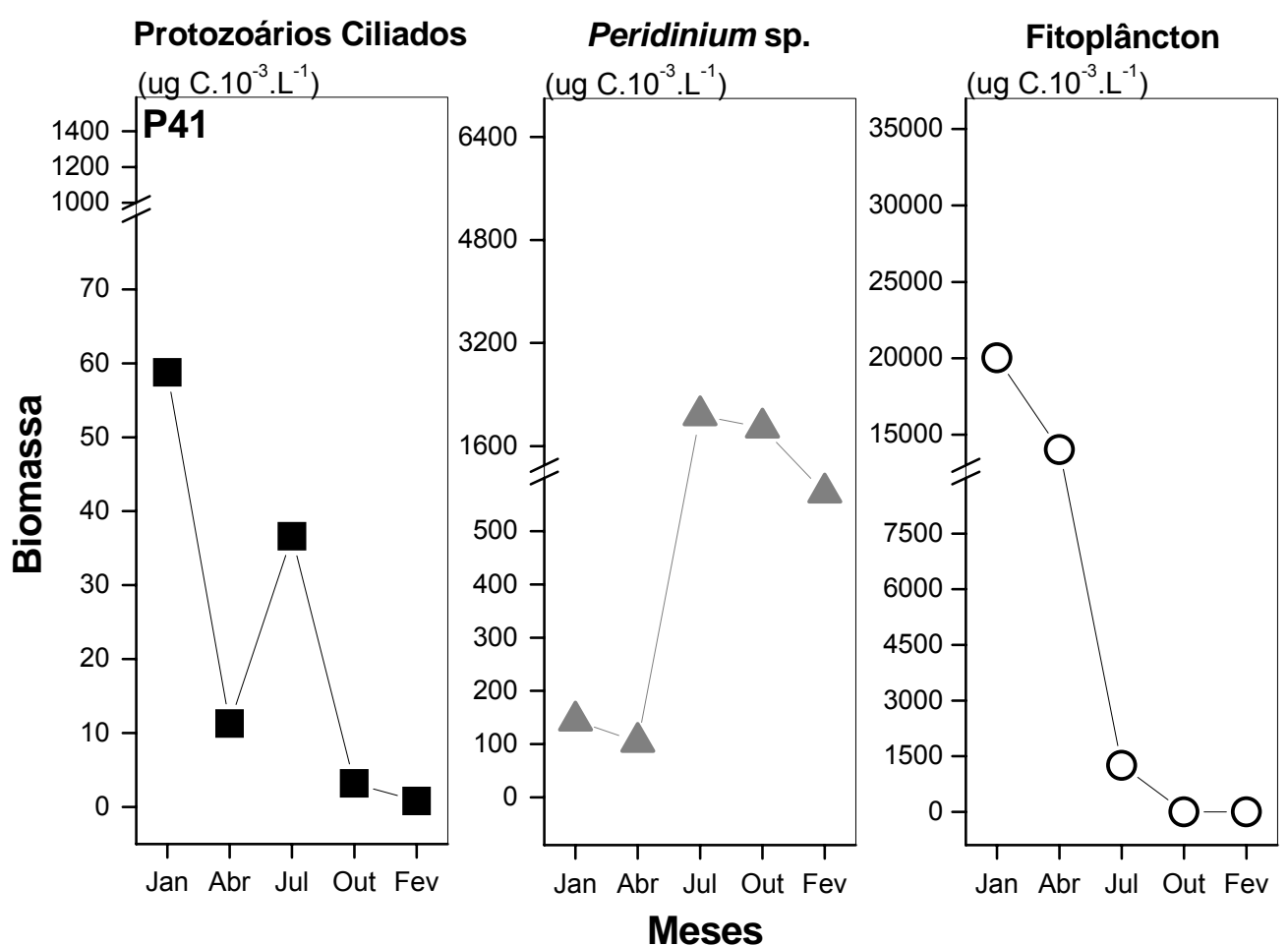

Figura $5(\mathrm{a} / \mathrm{b})$. Biomassa dos protozoários ciliados, do dinoflagelado Peridinium sp. e do fitoplâncton em diferentes pontos de amostragem na Represa das Antas, ao longo do período avaliado. 
5c. Ponto P14S.
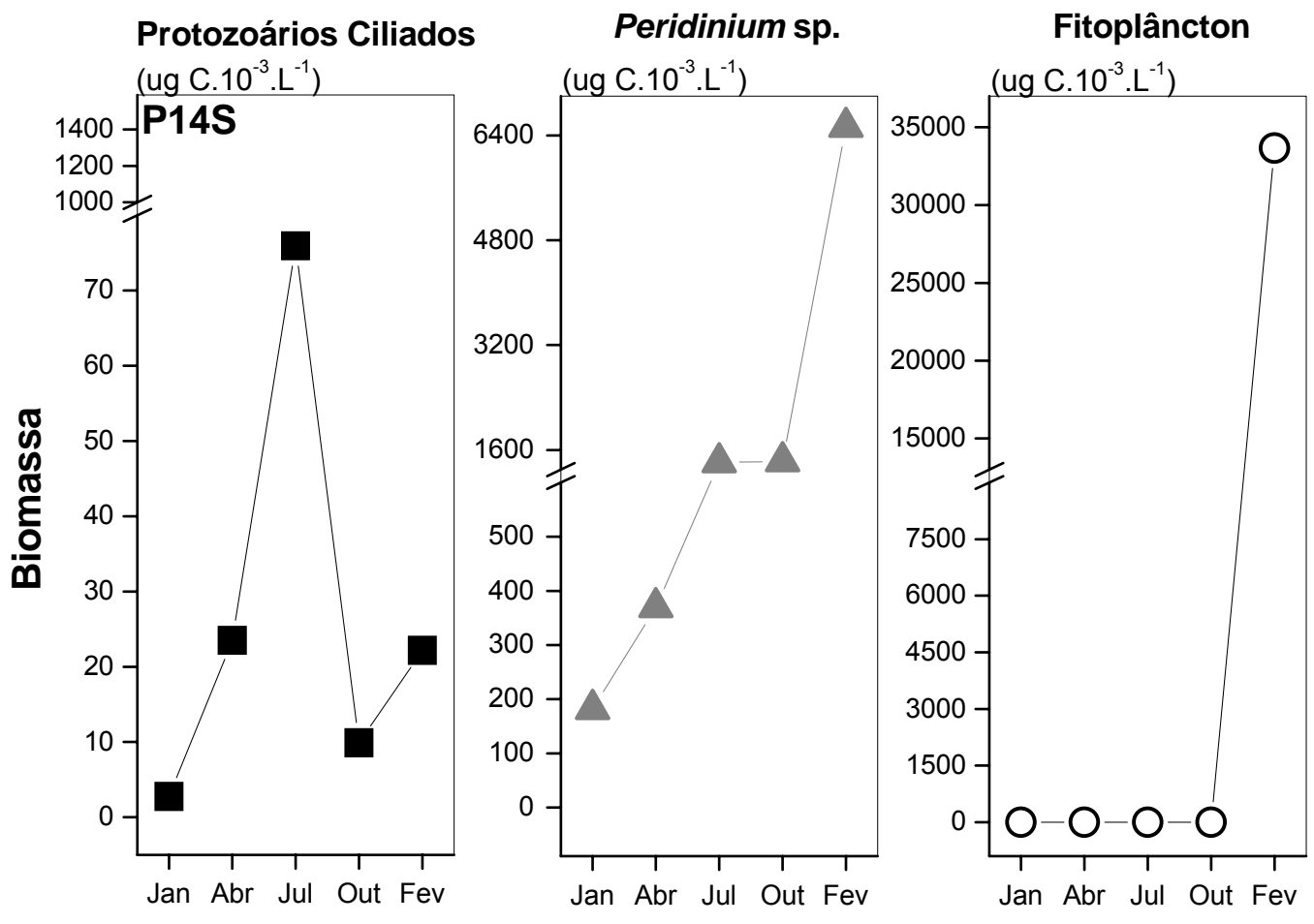

Meses

5d. Ponto P14F.
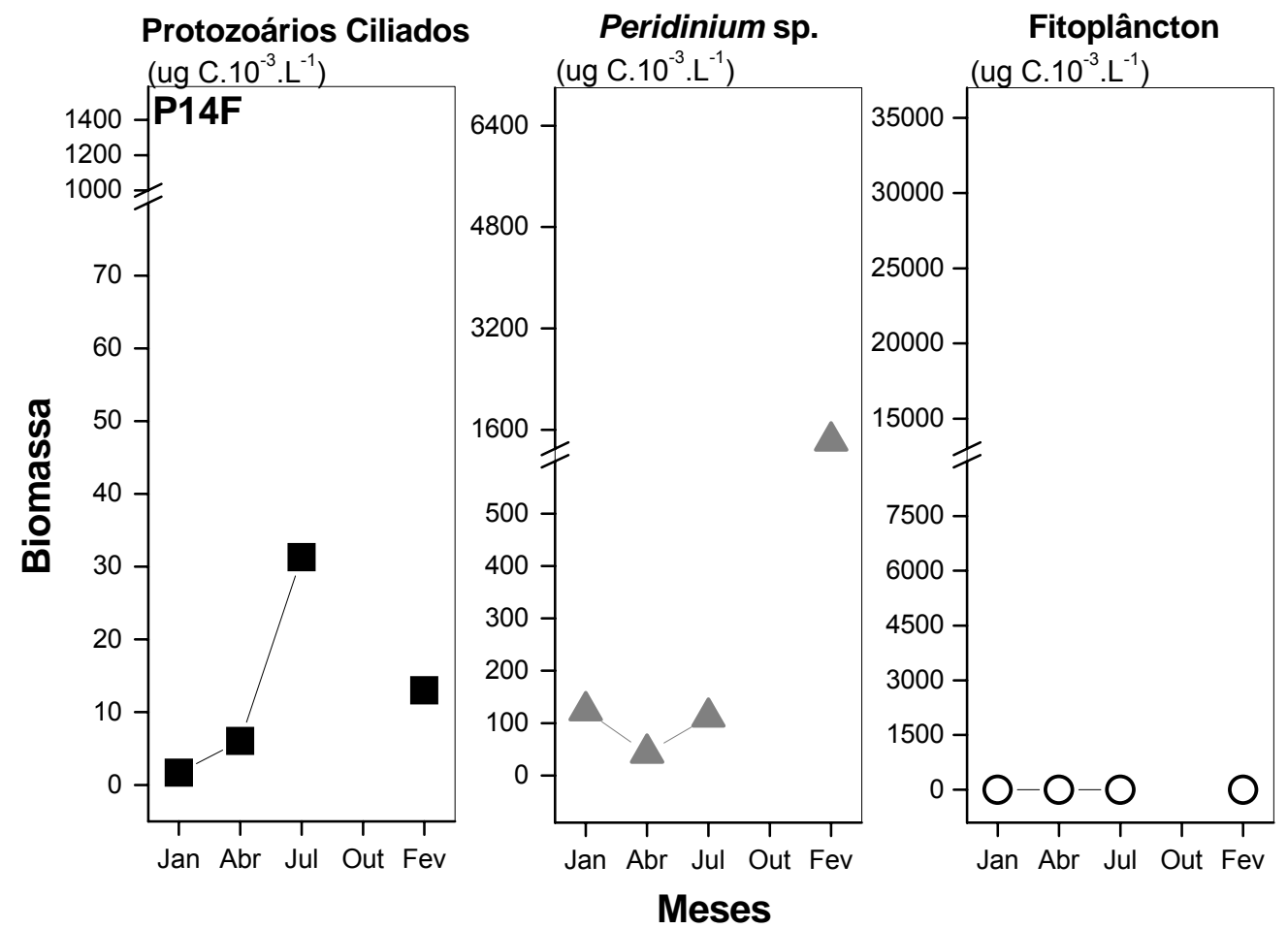

Figura 5(c/d). Biomassa dos protozoários ciliados, do dinoflagelado Peridinium sp. e do fitoplâncton em diferentes pontos de amostragem na Represa das Antas, ao longo do período avaliado. 


\subsection{3 Índice de Saprobidade}

Excetuando-se os resultados registrados em amostras de água coletadas em janeiro, a Represa das Antas foi classificada como um corpo aquático com nível de saprobidade beta-mesosapróbico durante todo o período avaliado, como mostra a Tabela 9.

Tabela 9. Índice de saprobidade obtido em amostras de água da Represa das Antas

\begin{tabular}{c|c|c}
\hline Meses & Índice de Saprobidade & Classificação \\
\hline Janeiro & 2,71 & alfa-mesosapróbico \\
\hline Abril & 2,46 & beta-mesosapróbico \\
\hline Julho & 2,21 & beta-mesosapróbico \\
\hline Outubro & 2,03 & beta-mesosapróbico \\
\hline Fevereiro & 2,25 & beta-mesosapróbico \\
\hline Valor Médio & & \\
\hline
\end{tabular}

$\mathrm{N}=20$

\subsection{4 Índice de Diversidade}

Os resultados do presente estudo mostraram que, somente no mês de julho foi observado o maior valor de índice de diversidade $\left(H^{\prime}=0,3134\right)$ em amostra de água procedente do mesmo ponto de amostragem, onde também foi detectado o maior valor de biomassa $\left(75,9 \mu \mathrm{g} \mathrm{C} \cdot 10^{-3} \cdot \mathrm{L}^{-1}\right)$, ou seja, no ponto P14S (Tabela 10).

De um total de cinco amostragens realizadas no presente estudo, em duas delas, as amostras de água procedentes do ponto P14S apresentaram os maiores valores de índice de diversidade, ou seja, para amostras de água coletadas no mês de julho e outubro (Tabela 10). Por outro lado, as amostras de água procedentes do ponto Cab, apresentaram na maior parte do período avaliado, os menores valores de índice de diversidade, ou seja, nos meses de abril, outubro e fevereiro (Figura 6).

Somente no mês de abril a amostra de água procedente do ponto P41 apresentou o maior valor de índice de diversidade quando comparado aos valores determinados em amostras dos demais pontos de amostragem. Esse comportamento também foi registrado para o ponto Cab no mês de janeiro. Por outro lado, o menor valor de índice de diversidade registrado em amostras de 
água procedentes da Represa das Antas durante todo o período avaliado ocorreu no ponto P41 $\left(H^{\prime}=0,000004\right)$ no mês de Julho (Figura 6).

De acordo com a Figura 6 verificou-se que valores de índice de diversidade registrados para amostras procedentes do ponto P41 e a jusante desse, apresentaram padrão de comportamento semelhante ao longo de todo o período avaliado, ou seja, foram registrados picos nos valores de índice de diversidade em amostras de água coletadas nos meses de abril e outubro e diminuição de valores nos meses de julho e fevereiro.

Tabela 10. Valores de Biomassa e Índice de Diversidade dos gêneros de protozoários ciliados obtidos em amostras de água da Represa das Antas

\begin{tabular}{|c|c|c|}
\hline Mês & Pontos & Índice de Diversidade \\
\hline \multirow{5}{*}{ Janeiro } & Cab & 0,408600 \\
\hline & $\mathrm{P} 41$ & 0,183900 \\
\hline & P14S & 0,301000 \\
\hline & P14F & 0,000400 \\
\hline & Média & 0,223500 \\
\hline \multirow{4}{*}{ Abril } & Cab & 0,131800 \\
\hline & P41 & 0,361100 \\
\hline & P14S & 0,336000 \\
\hline & P14F & 0,301000 \\
\hline & Média & 0,282500 \\
\hline \multirow{4}{*}{ Julho } & Cab & 0,148400 \\
\hline & $\mathrm{P} 41$ & 0,000004 \\
\hline & P14S & 0,313400 \\
\hline & P14F & 0,000040 \\
\hline & Média & 0,115500 \\
\hline \multirow{4}{*}{ Outubro } & Cab & 0,100500 \\
\hline & P41 & 0,276700 \\
\hline & P14S & 0,558500 \\
\hline & P14F & $\mathrm{X}$ \\
\hline & Média & 0,319100 \\
\hline \multirow{5}{*}{ Fevereiro } & Cab & 0,020700 \\
\hline & P41 & 0,239300 \\
\hline & P14S & 0,128800 \\
\hline & P14F & 0,347100 \\
\hline & Média & 0,184000 \\
\hline
\end{tabular}

$N=43$

$\mathrm{X}=$ não avaliado 


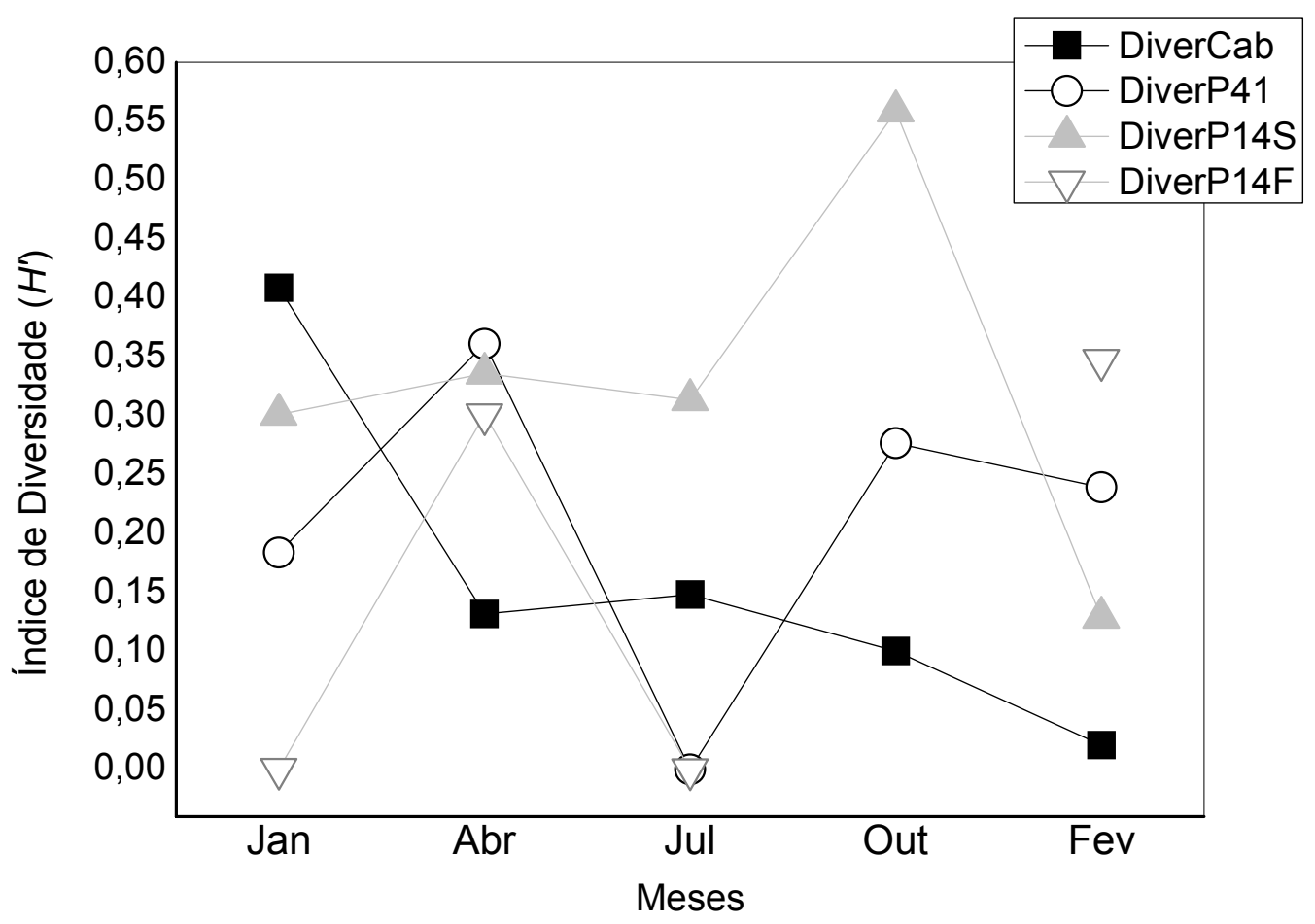

Figura 6. Valores de Índice de Diversidade (Diver) em amostras de água coletadas em diferentes pontos de amostragem na Represa das Antas. $N=43$

\section{DISCUSSÃO}

\subsection{Variáveis Físicas e Químicas}

No presente estudo, os valores obtidos para o índice pluviométrico e a temperatura do ar mostraram a existência duas estações durante os meses de estudo avaliados na Represa das Antas. O mês de julho caracterizado como seco e frio (menor índice pluviométrico e menor valor médio de temperatura), e os meses de janeiro/06, outubro/06 e fevereiro/07 representando a estação quente e úmida, apresentando elevados valores de precipitação e de temperatura do ar.

Durante o período de estudo, os valores médios de umidade relativa do ar apresentaram-se relativamente constantes em todos os meses avaliados, uma vez que, a Represa das Antas se localiza numa região de elevada altitude (altitude = 1291 m) próxima a Serra da Mantiqueira. De acordo com Nogueira; MatsumuraTundisi (1994), a análise dos principais fatores climatológicos tais como precipitação (índice pluviométrico), temperatura do ar, umidade relativa, 
velocidade do vento e evaporação podem ter importante influência na dinâmica do funcionamento do reservatório.

Os meses de maior intensidade dos ventos foram janeiro e outubro, porém, sendo ainda considerados calmos de acordo com a Escala Beaufort (Colégio São Francisco, 2008), indicando que esta variável climatológica provavelmente não causou turbulência na coluna d'água a ponto de desencadear um processo de ressuspensão de material do sedimento ao longo do perfil vertical na Represa das Antas. Tal hipóstese está de acordo com os baixos valores de sólidos em suspensão verificados em amostras de água nos meses de maior intensidade de vento, ou seja, valores de sólidos em suspensão variando de 0,005 a 0,006 mg. $\mathrm{L}^{-1}$ em janeiro e de 0,004 a $0,007 \mathrm{mg} \cdot \mathrm{L}^{-1}$ em outubro. Por outro lado, os maiores valores de sólidos em suspensão foram registrados em amostras de água coletadas nos meses de abril e fevereiro. Provavelmente a chuva detectada também nestes meses levou a ressuspensão do material presente no sedimento para a coluna de água e/ou possibilitou o carreamento de material da área de entorno para dentro da Represa das Antas.

O maior valor médio de condutividade observado em amostras de água coletadas na Represa das Antas, em julho de 2006, pode estar associado à menor precipitação observada neste mês, propiciando condições para concentração de íons na água (ESTEVES, 1998). Em fevereiro de 2007, o valor médio de condutividade elétrica foi também elevado e tal fato, pode estar relacionado à entrada do efluente tratado com hidróxido de cálcio, proveniente da bacia de decantação onde esse efluente fica armazenado. A capacidade da bacia de decantação que armazena o efluente tratado antes do lançamento na Represa das Antas é limitada. Durante o presente estudo, o elevado valor de índice pluviométrico foi registrado no mês de fevereiro. Dessa maneira, pode-se inferir sobre a possibilidade de que no mês de fevereiro o efluente tratado pela UTM-INB tenha sido lançado neste corpo aquático, antes que houvesse a precipitação adequada dos íons em solução. Esse evento também pôde ser evidenciado pelos elevados valores de condutividade elétrica da água detectados no ponto P41 (ponto de lançamento dos efluentes ácidos tratados) e a jusante deste (P14S e $\mathrm{P} 14 \mathrm{~F})$ no mês de fevereiro.

Os menores valores de $\mathrm{pH}$ foram registrados em amostras de água coletadas no mês de fevereiro, e podem também ter favorecido a presença de íons em 
solução (PACKROFF, 2000; WOLLMANN et al. 2000). Tais resultados concordaram com os elevados valores médios de condutividade também registrados no mês de fevereiro. Houve forte correlação negativa entre os valores de condutividade elétrica e pH para o mês de fevereiro $(r=-0,75)$. De acordo com Esteves (1998), corpos d'água com pH baixos são encontrados frequentemente em regiões vulcânicas, como é o caso da Represa das Antas.

Os resultados de $\mathrm{pH}$ detectados ao longo de todo o período de estudo na Represa das Antas foram ligeiramente ácidos. Valores de $\mathrm{pH}$ levemente ácidos em amostras de água provenientes da bacia hidrográfica do Ribeirão das Antas também já foram registrados por Lage-Filho (1996). Segundo esse mesmo autor, esses valores podem ser explicados pela disponibilização dos íons silicato, sódio e potássio presentes no sedimento para a coluna d'água, sendo um resultado da litologia da bacia. Também associado à litologia da bacia hidrográfica têm-se a ocorrência de pirita que pode ter também influenciado na acidez detectada nesse ambiente, uma vez que, está intimamente relacionada aos processos de drenagem ácida (GARCIA, 1989, SOUZA, 1995, CAMPOS, 2006). RegaliSeleghim (1992) estudando as comunidades planctônicas e bentônicas da Represa do Monjolinho (São Carlos - SP) também verificou valores de $\mathrm{pH}$ ligeiramente ácidos, que variaram de 6,34 a 7,09.

Em relação aos valores de temperatura da água, pode ser verificada a existência de três estações, uma com baixa temperatura no mês de julho (16,0 $\left.{ }^{\circ} \mathrm{C}\right)$, outra de elevada temperatura em outubro de $2006\left(26,0{ }^{\circ} \mathrm{C}\right)$ e outra representada pelos meses de janeiro/06, abril/06 e fevereiro/07 $\left(23,5{ }^{\circ} \mathrm{C}\right)$. A diferenca entre o maior e o menor valor médio de temperatura registrado em amostras de água da Represa das Antas foi de $10^{\circ} \mathrm{C}$.

Silva; Rodrigues (2005) também verificaram valores mais baixos de temperatura da água em julho $\left(17,7-18,5^{\circ} \mathrm{C}\right)$ do que em novembro $(22,7$ - 25,0 ${ }^{\circ} \mathrm{C}$ ) em estudos nos reservatórios do Rio Iguaçu (Paraná). De Fillipo et al. (2007), no reservatório Serra da Mesa (Goiás) realizando um programa de monitoramento neste corpo d'água verificaram o predomínio de maiores valores de temperatura da água nos meses de novembro a março $\left(30,0^{\circ} \mathrm{C}\right)$ e de menor valor no mês de julho $\left(26,5^{\circ} \mathrm{C}\right)$.

Comparando-se os resultados do presente estudo com aqueles obtidos nos estudos citados acima, de um modo geral, o valor da temperatura da água da 
Represa das Antas apresentou-se mais baixo, concordando com o esperado para a região de Poços de Caldas que apresenta clima tropical de altitude (LAGEFILHO, 1996).

As amostras de água procedentes da Represa das Antas mostraram-se bem oxigenadas espacial e sazonalmente ao longo do período avaliado. Os maiores valores médios de oxigênio dissolvido registrados em amostras de água no presente estudo foram verificados nos meses que apresentaram maior índice pluviométrico, ou seja, nos meses de janeiro/06, outubro/06 e fevereiro/07 (valor médio igual a 7,5 mg. $\mathrm{L}^{-1}$ ). Dabês et al. (1990), estudando as variáveis físicas e químicas em amostras de água da Represa de Pontal (Itabira, MG) também verificaram valores médios de oxigênio dissolvido da água maiores na estação chuvosa $\left(8,2 \mathrm{mg} \cdot \mathrm{L}^{-1}\right)$ do que na estação seca $\left(6,0 \mathrm{mg} \cdot \mathrm{L}^{-1}\right)$. Concentrações de oxigênio dissolvido em amostras de água dos reservatórios em cascata do Rio Tietê (São Paulo), no período chuvoso, foram superiores àquelas verificadas no período seco (RODGHER et al. 2005), concordando com os resultados obtidos no presente estudo.

Diferentemente dos resultados registrados no presente estudo, Vercellino; Bicudo (2006), estudando um reservatório tropical situado no Parque Estadual das Fontes do Ipiranga (São Paulo) verificaram que, os valores de oxigênio dissolvido em amostras de água procedentes da estação seca foram superiores $\left(8,4 \mathrm{mg} \cdot \mathrm{L}^{-1}\right)$ àqueles observados na estação chuvosa $\left(6,8 \mathrm{mg} \cdot \mathrm{L}^{-1}\right)$.

De acordo com Esteves (1998), a solubilidade do oxigênio na água depende da temperatura e da pressão atmosférica. Segundo o autor, com a elevação da temperatura espera-se que ocorra redução na solubilidade do oxigênio na água. No presente estudo, verificou-se correlação positiva moderada $(r=+0,6)$ entre as concentrações de oxigênio dissolvido e temperatura da água na Represa das Antas. Além disso, outro fator que deve ser considerado é o processo de fotossíntese, que ocorre na zona eufótica com a produção considerável de oxigênio (ESTEVES, 1998). No presente estudo houve fraca correlação positiva ( $r$ $=+0,1)$ entre os valores de oxigênio dissolvido e clorofila a na água.

No presente estudo, foram detectadas amostras de água apresentando concentrações de fluoreto, manganês, zinco, sulfato e urânio acima dos limites previstos pela Resolução 357 do Conama (CONAMA, 2005). De um modo geral, os maiores valores foram registrados em amostras de água procedentes do ponto 
P41, seguido do ponto P14F. De acordo com Nascimento (1988), os efluentes líquidos da UTM-INB, quando caracterizados quimicamente antes do tratamento para o lançamento no meio ambiente, apresentam teores elevados de fluoreto, manganês, zinco, sulfato, urânio, tório entre outros elementos. Sendo assim, a ocorrência de uma possível falha no sistema de tratamento dos efluentes pela UTM-INB pode explicar os elevados valores destes elementos no ponto P41 e a jusante deste. Lage-Filho (1996) relacionou as variadas concentrações de cálcio, manganês, molibdênio e urânio no sedimento do Ribeirão das Antas (Poços de Caldas - MG) à atividade de mineração de Urânio e sugeriu uma possível mobilização desses íons para o corpo d'água quando as condições físico-químicas do ambiente se alteram.

Wollman et al. (2000), analisando a concentração de sulfato em amostras de água de lagos ácidos (valores de $\mathrm{pH}$ entre 4,0 - 6,0) formados por atividades de mineração em Lusatia (Alemanha), encontraram faixa de variação para os valores de sulfato $\left(150\right.$ - $\left.1800 \mathrm{mg} \cdot \mathrm{L}^{-1}\right)$ superiores aquela observadas no presente estudo.

Estudos no rio Lot Garonne (França), localizado próximo a regiões de mineração com histórico de poluição por metais, apontaram concentrações de zinco variando de 0,006 - 0,66 mg.L $\mathrm{L}^{-1}$ (MASSON; BLANC; SCHÄFER, 2006). No presente estudo os valores de zinco registrados em amostras de água variaram de $<0,2-2,03 \mathrm{mg} \cdot \mathrm{L}^{-1}$.

Brandenberger et al. (2004) verificaram em um reservatório sub-tropical (Corpus Christi's - EUA), localizado em uma região de extração de urânio, concentrações de urânio na água variando de 0,001 - 0,011 mg. $\mathrm{L}^{-1}$. No presente estudo, o maior valor de urânio detectado em amostras de água $(<0,05-0,11$ mg. $\mathrm{L}^{-1}$ ) foi superior ao encontrado por Brandenberger et al. (2004).

Os valores de urânio (abril e outubro) detectados nos pontos P41 e P14S, acima dos limites estabelecidos pela Resolução 357 do CONAMA (CONAMA, 2005) foram sempre iguais ou inferiores, ao valor registrado no ponto Cab. Neste cenário, pode-se inferir que tais resultados estejam associados à radioatividade natural elevada da região onde se encontra a jazida de urânio. Cabe assim, uma observação quanto ao limite máximo para urânio estabelecido na Resolução 357 do CONAMA (CONAMA, 2005), uma vez que, não contempla a qualidade ecológica dos corpos d'água. 
O valor de tório em amostras de água da Represa das Antas detectado para o mês de janeiro, no ponto Cab, apresentou-se acima do limite estabelecido pelo Ofíco $n^{\circ}$ 50/SLC de junho de 1997 da Comissão Nacional de Energia Nuclear. Entretanto, como o ponto Cab encontra-se a montante do ponto (P41) de lançamento dos efluentes tratados pela UTM-INB, espera-se que tal valor esteja relacionado à radioatividade natural da região.

Em relação ao valor de concentração de tório em amostras de água da Represa das Antas, somente no ponto P14F, para o mês de julho, foi detectado valor acima do limite estabelecido pelo Ofíco no 50/SLC de junho de 1997 da Comissão Nacional de Energia Nuclear.

Em relação aos resultados de dureza registrados em amostras de água coletadas na Represa das Antas, os maiores valores foram determinados no ponto P41, seguido dos pontos P14S e P14F. Por outro lado, os menores valores de dureza foram detectados em amostras de água do ponto Cab, ou seja, a montante do ponto de lançamento dos efluentes da UTM-INB. Sendo assim, estes resultados provavelmente estiveram relacionados ao hidróxido de cálcio utilizado no sistema de tratamento de efluentes da UTM-INB (CIPRIANI, 2002) e lançado no ponto P41. A presença de valores elevados de dureza concordou com os elevados valores de condutividade elétrica detectada em amostras de água provenientes da Represa das Antas. Entretanto, a análise de correlação de Pearson demonstrou baixa correlação negativa entre os valores de dureza e condutividade $(r=-0,29)$.

De acordo com Silvano; Raya-Rodriguez (2003) os valores de dureza (356 a $536 \mathrm{mg} \cdot \mathrm{L}^{-1} \mathrm{CaCO}_{3}$ ) detectados na lagoa Azul (uma lagoa formada por lavra de mineração de carvão à céu aberto) localizada na cidade de Siderópolis (Santa Catariana) classificaram a água da mesma como "muito dura" segundo a classificação de Sperling (1995). Diferentemente do verificado para as amostras de água procedentes da Represa das Antas que apresentaram valores de dureza variando de $26,85 \mathrm{mg} \cdot \mathrm{L}^{-1}$ a $239 \mathrm{mg} \cdot \mathrm{L}^{-1}$, podendo ser classficadas como "mole" (< $50 \mathrm{mg} \mathrm{CaCO}_{3} / \mathrm{L}^{-1}$ ) e "dura" (entre 150 e $300 \mathrm{mg} \mathrm{CaCO}_{3} / \mathrm{L}^{-1}$ ).

Por outro lado, no mês de fevereiro houve forte correlação negativa entre os valores de condutividade elétrica da água e os valores de $\mathrm{pH}(r=-0,75)$, indicando que neste mês, comparativamente, os baixos valores de $\mathrm{pH}$ que provavelmente favoreceram a solubilidade dos íons em solução, exerceram maior influência para 
elevação do valor médio de condutividade elétrica, quando comparado à dureza. Ou seja, os elevados valores médios de concentração dos elementos químicos (fluoreto, manganês, zinco e sulfato) detectados em amostras de água da Represa das Antas, provavelmente, foram os principais agentes responsáveis pela elevação da condutividade elétrica da água.

Estudo realizado na microbacia do rio Fiorita (Siderópolis, Santa Catarina) que também tem sido impactada pela drenagem acida de mina de carvão apresentaram resultados que concordaram com aqueles registrados no presente estudo. Segundo os autores do estudo (POMPÊO et al. 2004), houve redução na qualidade da água em direção a parte baixa da bacia do rio Fiorita, com diminuição do $\mathrm{pH}$, bem como elevação nos valores de acidez total, de condutividade elétrica, de potencial de oxido-redução e nos teores de sólidos totais, de sulfato, de alumínio, de cálcio, de ferro II, de ferro total, de manganês e de magnésio. De acordo com os mesmos autores, esses dados sugerem que em direção à parte baixa da bacia houve efeito de concentração, particularmente de metais devido a oxidação da pirita formando ácido sulfúrico, promovendo a solubilização dos minerais presentes no rejeito.

Foram verificados elevados valores para dureza, fluoreto, manganês, zinco e sulfato em amostras de água provenientes da Represa das Antas nos meses de julho/06 e fevereiro/07. Tais valores ocorreram em amostras de água procedentes de todos os pontos avaliados no mês de julho, diferentemente do que ocorreu no mês de fevereiro. Em fevereiro, os maiores valores de dureza, fluoreto, manganês, zinco e sulfato foram detectados no ponto de lançamento dos efluentes líquidos tratados pela UTM-INB (P41) e a jusante desse, ou seja, nos pontos P14S e P14F.

No mês de fevereiro foram detectados elevados valores de precipitação pluviométrica, aumentando o volume de água contido na bacia de decantação onde ocorre o tratamento dos efluentes líquidos da UTM-INB. Tal aumento no volume da água devido à ação das chuvas pode ter levado a liberação desse efluente para a Represa das Antas antes que o processo de precipitação dos íons em solução fosse completo, já que os elevados valores para dureza, fluoreto, manganês, zinco e sulfato foram detectados somente a partir do ponto P41 e a jusante desse. 
Por outro lado, no mês de julho foi detectado o menor valor de precipitação pluviométrica ao longo do período estudado, provavelmente possibilitando a concentração dos íons solúveis na água, bem como a ocorrência de processos biogeoquímicos não avaliados no presente estudo. Tais fatores podem ter contribuido para os elevados valores de dureza, fluoreto, manganês, zinco e sulfato em solução, desde o ponto Cab até os pontos P14S e P14F.

No caso dos elementos químicos avaliados (fluoreto, manganês, zinco e sulfato) os resultados mostraram que, tanto no mês de julho quanto no mês de fevereiro, houve pico nos valores desses elementos no ponto P41. Por outro lado, foram detectados elevados valores de dureza no ponto P41 (julho e fevereiro). Porém, somente a jusante do ponto P41 (P14S e P14F) para o mês de julho, os valores de dureza permaneceram elevados. Para o mês de fevereiro houve redução nos valores de dureza nos pontos a jusante do ponto $\mathrm{P} 41$, ou seja, P14S e P14F.

A redução nas concentrações dos elementos químicos avaliados (fluoreto, manganês, zinco e sulfato) na Represa das Antas nos pontos P14S e P14F nos meses de julho e fevereiro, provavelmente não ocorreram devido à precipitação dos elementos químicos pela formação de hidróxidos e compostos de cálcio, uma vez que, os valores médios de $\mathrm{pH}$ detectados respecticvamente, nos meses de fevereiro e julho, ou seja, 5,6 e 6,2 não favorecem a precipitação dos hidróxidos (hidróxido de manganês e hidróxido de zinco) e compostos de cálcio (sulfato de cálcio e fluoreto de cálcio) (LIDE, 2004).

As concentrações de fósforo total detectadas em amostras de água provenientes da Represa das Antas apresentaram valores relativamente baixos $\left(<0,01 \mathrm{mg} \cdot \mathrm{L}^{-1}\right)$ ao longo de todos os meses e pontos de amostragem avaliados. Valores de fósforo total de $143,83 \mu \mathrm{g} \cdot \mathrm{L}^{-1}$ foram encontrados por Moura; Dantas; Bittencourt-Oliveira (2007) nas amostras de água no Reservatório de Carpina (Pernambuco), caracterizado como um ambiente eutrófico. Velho et al. (2005) estudaram a qualidade da água dos reservatórios Irai (eutrófico), Rosana (oligomesotrófico) e Chavantes (oligotrófico) no estado do Paraná e verificaram valores de fósforo total iguais a $54,30,10,35$ e $7,19 \mu \mathrm{g} \cdot \mathrm{L}^{-1}$, respectivamente. De acordo com Esteves (1998), o fósforo total presente nos ecossistemas aquáticos podem ter origem natural ou artificial, sendo a artifical caracterizada pelos efluentes industriais e agrícolas. No presente estudo, os baixos valores de fósforo 
total detectados nas amostras de água da Represa das Antas estão de acordo com os valores obtidos para ambientes oligotrófico e oligomesotrófico observados nos estudos acima citados.

No presente estudo, a Represa das Antas foi classificada como um corpo aquático oligotrófico com base nos valores de IET para clorofila a e de IET para transparência da água. Segundo Toledo et al. (1983) ambientes oligotróficos são corpos de água limpos, de baixa produtividade, em que não ocorrem interferências indesejáveis sobre os usos da água. A Represa das Antas apresenta descarga de fundo provida de comporta plana, planejada visando a um maior controle dos processos de eutrofização no reservatório (RELATÓRIO AMBIENTAL INB, 1999). Exemplos de reservatórios considerados eutróficos são o de Barra Bonita (Barra Bonita - SP) com IET para fósforo total igual a 66,17 (TUNDISI, 2001) e a represa da Carpina (Estado de Pernanbuco) com IET para transparência da água igual a 60,0. Bezerra-Neto; Pinto-Coelho (2002) estudando a morfometria e o estado trófico do reservatório do Nado (Belo Horizonte - MG) classificaram este corpo d'água como meso-eutrófico (IET para clorofila aproximadamente igual a 50,0). Em relação aos reservatórios meso-oligotróficos, tem-se o Reservatório do Lobo (São Carlos - SP) com valor IET igual a 47,76 (ABE et al. 2000) e o Reservatório de Três Irmãos (São Paulo) com valor de IET para clorofila a de 39,0 (FRACÁCIO et al. 2001).

\subsection{Variáveis Biológicas}

\subsubsection{Relações tróficas dos tipos nutricionais, Classe e Gêneros dos protozoários ciliados, do dinoflagelado Peridinium sp. e outras populações microbianas planctônicas}

Foram verificadas correlações entre os valores percentuais médios de biomassa e densidade dos tipos nutricionais dos protozoários ciliados predominantes e do dinoflagelado Peridinium sp. na Represa das Antas com os valores de densidade bacteriana, de biomassa fitoplanctônica, concentrações de clorofila $b$ e $c$, bem como, com os valores de densidade e biomassa do dinoflagelado Peridinium sp. 
O valor percentual médio de biomassa dos protozoários ciliados incluídos na categoria trófica de bac/alg, predominantes em amostras de água procedentes da Represa das Antas no mês de janeiro, apresentaram forte correlação positiva com o valor médio de biomassa fitoplanctônica $(r=0,99)$, fraca correlação positiva em relação aos valores de densidade bacteriana $(r=0,37)$ e fraca correlação negativa, tanto para os valores médios de biomassa quanto para os valores médios de densidade do dinoflagelado Peridinium sp. $(r=-0,35)$.

Para o mês de abril, quando o valor percentual médio de biomassa do tipo nutricional dos bac/alg continuou predominando, houve fraca correlação negativa desses ciliados com o valor médio de biomassa fitoplanctônica $(r=-0,15)$ e fraca correlação positiva com o valor médio de densidade bacteriana $(r=0,17)$. Por outro lado, o valor médio de biomassa para o tipo nutricional bac/alg apresentou forte correlação positiva tanto para os valores médios de biomassa $(r=0,99)$ quanto para os valores médios de densidade $(r=0,98)$ do dinoflagelado Peridinium sp.

Com base nas correlações acima verificadas, podemos observar que a principal fonte de alimento para o tipo nutricional bac/alg dos protozoários ciliados procedentes de amostras de água coletadas nos meses de janeiro e abril foi provavelmente de origem autotrófica, seguida de menor pressão de predação sobre o bacterioplâncton presente neste reservatório. Regali-Seleghim (2001) também verificou dominância do tipo nutricional bac/alg no Reservatório do Monjolinho (São Carlos - SP). Segundo o autor, a predominância desse tipo nutricional nesse ecossistema aquático foi atribuída à facilidade de adaptação dos protozoários bacterívoros/algívoros frente às flutuações na disponibilidade de alimento, ora se alimentando de organismos autotróficos, ora se alimentando do bacterioplâncton. Em uma revisão sobre a importância da predação exercida pelos protozoários na rede alimentar microbiana em oceanos e em ambientes de água doce, Sherr; Sherr (2002) citaram que os estudos realizados na região pelágica têm confirmado que os principais responsáveis pela mortalidade do bacterioplâncton são os protistas. Além disso, Sherr; Sherr (2002) atribuem aos protozoários herbívoros um papel tão importante quanto ou mais do que o dos bacterívoros no impacto sobre a rede alimentar microbiana em ambientes de água doce e salgada, porém, tal hipótese não foi totalmente confirmada, pois ainda faltam informações acerca do impacto dos protistas herbívoros em ambientes de água doce. 
Nos meses de julho, outubro e fevereiro, o valor percentual médio de biomassa do tipo nutricional ki/alg/bac apresentou dominância em relação aos valores registrados em amostras de água procedentes dos demais meses de amostragem, ou seja, janeiro e abril.

Em julho foi verificada forte correlação positiva entre o valor percentual médio de biomassa dos ciliados ki/alg/bac e o valor médio de densidade bacteriana $(r=$ $0,95)$, forte correlação negativa com o valor médio de biomassa fitoplanctônica $(r=$ -0,90), moderada correlação negativa com o valor médio de densidade do dinoflagelado Peridinium sp. $(r=-0,68)$ e forte correlação negativa com o valor médio de biomassa do dinoflagelado Peridinium sp. $(r=-0,78)$.

No mês de outubro o valor percentual médio de biomassa dos protozoários ciliados ki/alg/bac apresentou forte correlação positiva, tanto para os valores médios de biomassa $(r=0,99)$ quanto para os valores médios de densidade $(r=$ 0,99) do dinoflagelado Peridinium sp., bem como forte correlação negativa para o valor médio de densidade bacteriana $(r=-0,9)$. A forte correlação negativa dos ki/alg/bac em relação ao valor médio de densidade bacteriana poderia ser explicada devido ao fato de que os Oligotrichas estivessem exercendo um controle tipo top-down sobre o bacterioplâncton, a ponto de suprimir o crescimento destes organismos. Estes resultados concordaram com aqueles observados por Conty; García-Criado (2007), que estudaram as relações entre os ciliados e o bacterioplâncton, bem como de outros grupos biológicos (fitoplâncton e zooplâcnton) a fim de identificar os principais fatores envolvidos na regulação destas comunidades em diferentes lagos da Espanha. Fato semelhante foi descrito por Burns; Galbraith (2007) em corpos aquáticos de água doce na Nova Zelândia, onde a biomassa das picocianobactérias apresentou correlação negativa com os valores de biomassa dos ciliados, sugerindo que 0 consumo das picocianobactérias pelos ciliados estaria suprimindo-as. Por outro lado, quando foi verificada correlação positiva, os autores inferiram que os ciliados podiam estar consumindo as picocianobactérias, mas não suprimindo a população.

No mês de fevereiro, o valor percentual médio de biomassa do tipo nutricional $\mathrm{ki} / a$ lg/bac apresentou forte correlação positiva com o valor médio de densidade do dinoflagelado Peridinium sp. $(r=0,90)$, porém correlação fraca positiva com o valor médio de biomassa de Peridinium sp. $(r=0,30)$, correlação negativa fraca com o valor médio de biomassa fitoplanctônica $(r=-0,12)$ e correlação positiva bem fraca 
com o valor médio de densidade bacteriana $(r=0,14)$. Para essas variáveis, onde foram verificadas fracas correlações com os ki/alg/bac infere-se sobre a possibilidade de que outros organismos estivessem utilizando essas fontes de alimento, ou seja, os ki/alg/bac talvez não estivessem exercendo uma forte pressão de predação sobre a biomassa fitoplanctônica e do dinoflagelado Peridinium sp., bem como sobre a densidade bacteriana. Por outro lado os ki/alg/bac poderiam estar predando as algas diatomáceas, uma vez que, é uma de suas preferências alimentares. Tal relação foi verificada pela correlação negativa detectada entre o valor médio de biomassas dos ki/alg/bac e o valor médio de clorofila $c$ para o mês de fevereiro $(r=-0,35)$.

Tal hipótese pôde ser suportada quando verificou-se que em fevereiro, exatamente para estas fontes de alimento (biomassa fitoplanctônica e do dinoflagelado Peridinium sp. e a densidade bacteriana) que não estavam sendo utilizadas ou facilmente disponíveis para os ki/alg/bac, verificou-se correlações fortes e moderadas com os tipos nutricionais bac/alg (Peritrichia - Campanella umbellaria) e Omnívoros (Gymnostomatida - Paradileptus elephantinus e Enchelys $\mathrm{sp}$.). Foram registradas correlações positivas fortes entre o valor percentual médio de biomassa dos ciliados bac/alg em relação ao valor médio de biomassa fitoplanctônica $(r=0,97)$ e ao valor médio de biomassa do dinoflagelado Peridinium sp. $(r=0,79)$; foi detectada correlação negativa moderada entre o valor percentual médio de biomassa dos ciliados bac/alg e o valor médio de densidade bacteriana ( $r$ $=-0,54)$. Além disso, foram verificadas correlações negativas moderadas entre o valor percentual médio de biomassa dos ciliados Omnívoros em relação ao valor médio de biomassa fitoplanctônica $(r=-0,45)$, ao valor médio de biomassa do dinoflagelado Peridinium sp. $(r=-0,45)$, ao valor médio de densidade do dinoflagelado Peridinium sp. $(r=-0,57)$, bem como para o valor médio de densidade bacteriana $(r=-0,52)$.

De acordo com os resultados apresentados acima, verificou-se que os bac/alg, os Omnívoros e os ki/alg/bac provavelmente estivessem se alimentando do Peridinium sp. no mês de fevereiro. Os protozoários ciliados bac/alg (Campanella umbellaria) e os Omnívoros (Paradileptus elephantinus) são protozoários relativamente maiores que os ki/alg/bac (Strombidium sp.) detectados nesse estudo. Sendo assim infere-se que, provavelmente, os bac/alg e os Omnívoros estavam se alimentando das maiores células de Peridinium sp. (correlações forte e 
moderada com o valor médio de biomassa do dinoflagelado e correlação fraca com o valor médio de densidade do dinoflagelado) enquanto que, os ki/alg/bac provavelmente estavam se alimentando das menores células de Peridinium sp. (correlação fraca com o valor médio de biomassa do dinoflagelado e correlação forte com o valor médio de densidade do dinoflagelado). Beaver; Crisman (1989) relatam que os ciliados podem ser vorazes predadores tanto do bacterioplâncton quanto do fitoplâncton, e que cada espécie de ciliado possui uma distinta faixa de preferência de tamanho da presa, que é uma função da sua morfologia e do tamanho da estrutura bucal.

No mês de outubro, o valor percentual médio de biomassa do tipo nutricional auto/bac procedentes de amostras de água da Represa das Antas apresentaram forte correlação negativa com o valor médio de densidade bacteriana $(r=-0,85)$, bem como, moderada correlação positiva com o valor médio de clorofila $c(r=$ $0,57)$. Tais correlações indicam que possivelmente o dinoflagelado Peridinium sp. estaria exercendo forte pressão de predação (tipo "top-down") sobre o bacterioplâncton. Ainda no mês de outubro, foi também registrada a ocorrência de fortes correlações negativas entre o valor percentual médio de biomassa dos tipos nutricionais bac/alg $(r=-0,97)$, bac/flag $(r=-0,90)$, omnívoros $(r=-0,94)$, ki/alg/bac $(r=-0,90)$ e R-predador $(r=-0,90)$ com o valor médio de densidade bacteriana. Esse tipo de comportamento pode estar relacionado à disponibilidade e qualidade do alimento, uma vez que, neste mês foi registrado o segundo maior valor médio de densidade bacteriana.

A hipótese de disponibilidade de fonte de alimento pôde ser sustentada, uma vez que em outubro, foi o único mês onde se registrou a ocorrência simultânea de todos os oito gêneros de protozoários ciliados e todas as categorias tróficas registradas nas amostras de água da Represa das Antas. Associado a esse fato, foram também verificadas fortes correlações positivas entre o valor percentual médio de biomassa dos tipos nutricionais dos bac/alg $(r=0,71)$, dos bac/flag $(r=$ $0,99)$, dos Omnívoros $(r=0,98)$, dos ki/alg/bac $(r=0,99)$, bem como, para o Rpredador $(r=0,99)$ com o tipo nutricional auto/bac (Peridinium sp.).

No mês de fevereiro, o valor percentual médio de biomassa do tipo nutricional auto/bac (dinoflagelado mixotrófico Peridinium sp.) procedentes de amostras de água da Represa das Antas apresentou fortes correlações positivas com o valor médio de clorofila a $(r=0,91)$ e com o valor médio de clorofila $c(r=0,79)$, bem 
como, moderada correlação negativa com o valor médio de densidade do bacterioplâncton $(r=-0,49)$. Tais correlações podem indicar que o dinoflagelado Peridinium sp. neste mês estivesse utilizando da mixotrofia, devido a correlação registrada para os valores de densidade do bacterioplâncton e clorofila a e $c$. No mês de feveriero o dinoflagelado Peridinium $\mathrm{sp}$. foi o organismo fitoplanctônico dominante, representando $24 \%$ em relação ao valor medio total de biomassa fitoplanctônica para o mês de fevereiro, corroborando com a hipótese de metabolismo mixotrofico. De acordo com Stoecker (1999) e Tittel et al. (2003), entre os dinoflagelados mixotróficos, muitas espécies são primariamente fototróficas, podendo assimilar nutrientes inorgânicos dissolvidos, porém, utilizam a fagotrofia para suplementar nutrientes inorgânicos limitados e/ou aumentar sua taxa de crescimento.

Em relação ao valor percentual médio de densidade dos tipos nutricionais observados durante o período de estudo na Represa das Antas, os ciliados Omnívoros predominaram em amostras de água coletadas em janeiro e apresentaram moderada correlação positiva em relação ao valor médio de biomassa fitoplanctônica $(r=0,66)$, bem como fracas correlações negativas em relação ao valor médio de densidade bacteriana $(r=-0,17)$, densidade $(r=-0,3)$ e biomassa $(r=-0,2)$ do dinoflagelado Peridinium sp. Provavelmente estes ciliados estivessem se alimentando concomitantemente de algas e de outras fontes de alimento não avaliadas neste estudo, tais como pequenos flagelados autotróficos e heterotróficos, protozoários menores, metazoários menores, ovos de metazoários e pequenos crustáceos (FOISSNER; BERGER; SCHAUMBURG, 1999 e SHERR; SHERR, 2000).

Para o mês de abril, os ciliados bac/alg predominaram (67\%) quanto ao valor percentual médio de densidade em relação aos demais tipos nutricionais de protozoários ciliados registrados. Esses organismos apresentaram fraca correlação positiva com o valor médio de densidade bacteriana $(r=0,21)$, forte correlação positiva com o valor médio de densidade $(r=0,98)$ e biomassa $(r=0,98)$ do dinoflagelado Peridinium sp., bem como fraca correlação negativa com o valor médio de biomassa fitoplanctônica $(r=-0,11)$. Os resultados de correlação não mostraram forte pressão de predação dos bac/alg sobre o dinoflagelado Peridinium sp., devido a ausência de correlação negativa. Entretanto, durante a análise microscópica das amostras de água da Represa das Antas, foram registrados 
freqüentemente no interior da Campanella umbellaria, células de Peridinium sp., podendo estar relacionado a predação deste ciliado sobre o dinoflageldo Peridinium sp. ou por possíveis relações de simbiose entre eles.

Relações de mixotrofia têm sido verificadas entre organismos fitoplanctônicos e protozoários. Como exemplo, a relação de mixotrofia entre o protozoário ciliado Mesodinium rubra, o qual apresenta associações com algas criptofíceas endosimbiontes ou o seqüestro ou ingestão de plastídeos de organismos fotossintetizantes pelos ciliados oligotriquidas (LAYBOUN-PARRY, 1992). Segundo o mesmo autor, a maioria das situações de simbiose envolve algas zooclorelas e zooxantelas endosimbióticas; ocorrendo em muitos ciliados, amebas, radiolária e foraminífera.

Este estudo realizado na Represa das Antas registrou pela primeira vez a presença do dinoflagelado Peridinium sp. no interior do protozoário ciliado Campanella umbellaria. Sendo assim, provavelmente outras variáveis não avaliadas neste estudo podem estar relacionadas à forte correlação positiva dos bac/alg (Campanella umbellaria) com os valores médios de densidade e biomassa do dinoflagelado Peridinium sp., além da relação de presa-predador existente entre eles.

Para o mês de julho, o tipo nutricional dominante em relação ao valor percentual médio de densidade foram os $\mathrm{ki} / \mathrm{alg} / \mathrm{bac}$ apresentando moderada correlação positiva com o valor médio de densidade bacteriana $(r=0,66)$, bem como, fortes correlações negativas com o valor médio de densidade $(r=-0,79)$, de biomassa $(r=-0,81)$ do dinoflagelado Peridinium sp. e com o valor médio de biomassa fitoplanctônica $(r=-0,76)$. Tais correlações poderiam indicar que os ciliados ki/alg/bac (Oligotrichas - Strombidium sp.) estivessem se alimentando de bactérias, do dinoflagelado e do fitoplâncton. Foissner et al. (1999) destaca que o ciliado Strombidium sp. é um organismo versátil por ter sempre alguma fonte de alimento ao seu alcance (devido ao metabolismo mixotrófico), por ser comum em todas as estações do ano e tolerante a grandes variações de temperatura.

Nos meses de abril e julho, os Omnívoros foram o segundo grupo mais representativo em relação aos valores percentuais médios de densidade. Esses ciliados apresentaram forte correlação positiva com o valor médio de densidade bacteriana $(r=0,80)$ e com o valor médio de biomassa fitoplanctônica $(r=0,80)$ para o mês de abril. Em relação ao mês de julho, foram verificadas moderadas 
correlações positivas entre o valor percentual médio de densidade dos ciliados Omnívoros e o valor médio de densidade $(r=0,59)$ e de biomassa $(r=0,45)$ do dinoflagelado Peridinium sp.

Ainda que os omnívoros tenham sido o segundo tipo nutricional em termos de importância relativa nos valores médios de densidade nos meses de abril e julho, devido a disponibilidade de fontes de alimento, uma vez que, no mês de abril foi registrado o maior valor médio de densidade bacteriana e elevado valor médio de biomassa fitoplanctônica. Além disso, no mês de julho foi registrado elevado valor médio de densidade e de biomassa do dinoflagelado Peridinium sp., ou seja, a provável maior disponibilidade e qualidade de fontes de alimento favorecendo a codominância dos Omnívoros.

Em outubro o tipo nutricional dominante em relação ao valor percentual médio de densidade foi compartilhado entre os Omnívoros, os ki/alg/bac, e os bac/flag. $\mathrm{O}$ valor médio de densidade dos Omnívoros, dos ki/alg/bac e dos bac/flag apresentaram forte correlação positiva com o valor médio de densidade (omnívoros: $r=0,99$; ki/alg/bac: $r=0,98$; bac/flag: $r=0,99$ ) e biomassa (omnívoros: $r=0,99$; ki/alg/bac: $r=0,97$; bac/flag: $r=0,99$ ) de Peridinium sp. Para os três tipos nutricionais citados acima foram verificadas fortes correlações negativas com os valores de densidade bacteriana também (omnívoro: $r=-0,90$; ki/alg/bac: $r=-0,96$; bac/flag: $r=-0,92)$. Tais correlações podem indicar que esses tipos nutricionais estivessem se beneficiando do elevado valor médio de densidade bacteriana $\left(5,7.10^{9}\right.$ ind. $\left.L^{-1}\right)$, do elevado valor médio de biomassa $\left(313.10^{-3} \mu \mathrm{g} \mathrm{C.} \mathrm{L}^{-1}\right)$, bem como, do maior valor médio de densidade (44.197 ind. $\left.\mathrm{L}^{-1}\right)$ do dinoflagelado Peridinium sp. registrado em amostras de água provenientes do mês de outubro na Represa das Antas. Uma vez que, os Omnívoros, ki/alg/bac e os bac/flag são predadores de flagelados e do fitoplâncton (FOISSNER; BERGER; SCHAUMBURG, 1999 e LAYBOURN-PARRY, 1992).

No mês de fevereiro, o tipo nutricional dominante em relação ao valor percentual médio de densidade dos ciliados em amostras de água provenientes da Represa das Antas foram os ki/alg/bac, como já registrado anteriormente no mês de julho. O valor percentual de densidade do ki/alg/bac apresentou forte correlação positiva em relação ao valor médio de densidade do dinoflagelado Peridinium sp. ( $r$ $=0,94$ ), bem como correlações negativas extremamente fracas em relação ao valor médio de densidade bacteriana $(r=0,18)$ e biomassa fitoplanctônica $(r=-0,04)$. 
Provavelmente os ki/alg/bac estivessemm se alimentando do dinoflagelado Peridinium sp., bom como de organismos autotróficos não contemplados neste estudo como as algas diatomáceas.

O maior valor percentual médio de densidade e biomassa do tipo nutricional auto/bac foi registrado no mês de fevereiro. Foram verificadas correlações bem fracas entre o valor médio de densidade do dinoflagelado Peridinium sp. e o valor médio de biomassa fitoplanctônica $(r=0,23)$, valor médio de densidade bacteriana $(r=0,19)$ e o valor médio de clorofila $b(r=-0,37)$ e $c(r=-0,004)$ em amostras de água da Represa das Antas. Sendo assim, provavelmente outras variáveis não avaliadas neste estudo poderiam estar relacionadas ao elevado valor percentual médio do tipo nutricional auto/bac registrado em amostra de água da Represa das Antas analisada no mês de fevereiro.

No presente estudo, observou-se a dominância dos ciliados ki/alg/bac (Oligotricha - Strombidium sp.) em relação aos valores médios percentuais de densidade $(48 \%)$ e biomassa $(82,3 \%)$ ao longo de todo o período de estudo avaliado em relação aos demais tipos nutricionais de protozoários ciliados. Biyu (2000) no lago Biandantang (China) também verificou que os oligotriquidas (Strombidium viride, Strobilidium caudatum e Halteria grandinella) foram o grupo mais importante. Segundo esse autor, o ciliado Strombidium viride se alimentou de diatomáceas, além de hospedar algas endosimbiontes. De acordo com Gilbert (1994) e Biyu (2000), provavelmente, a ampla distribuição dos ciliados oligotriquidas se dê pela habilidade de nadar rapidamente, além da capacidade de saltar, o que facilitaria o escape da predação exercida pelo metazooplâncton.

Podemos inferir com base nas variáveis analisadas que na Represa das Antas a fonte de alimento dos organismos é fornecida tanto pelos organismos autotróficos (tanto pela mixotrofia quanto, provavelmente pela ingestão direta de células algais) como pelas bactérias.

A predominância de ciliados com preferência alimentar por algas e bactérias pode ser explicada pela facilidade de adaptação às flutuações na disponibilidade de alimento destes organismos (REGALI-SELEGHIM, 2001). Grande parte dos organismos registrados neste estudo possuindo esses hábitos alimentares correspondeu ao ciliado Oligotricha Strombidium sp.. Segundo Regali-Seleghim (2001) os Oligotricha são um dos mais importantes grupos em ambientes aquáticos 
planctônicos, provavelmente por apresentar essa estratégia alimentar, além de pequenas dimensões que determinam rápidas taxas de crescimento.

Segundo Burns; Galbraith (2007) e Porter et al. (1988) em ambientes oligotróficos como a Represa das Antas, as bactérias possuem papel principal na ciclagem de nutrientes e nos fluxos de energia, consequentemente na rede alimentar microbiana, uma vez que, nestes corpos aquáticos a produção primária é muito baixa devido às baixas concentrações de nutrientes, explicando assim a preferência alimentar por células bacterianas como uma das principais fontes de alimento para os ciliados planctônicos neste corpo aquático.

Além da predominância do tipo nutricional ki/alg/bac, outra forma de obtenção de energia utilizada pelos organismos avaliados na Represa das Antas foi a presença do metabolismo mixotrófico utilizado tanto pelo ciliado Strombidium sp., que obtém energia através de relações de endosimbiose ou pelo seqüestro de plastídeos de células algais e de flagelados, bem como, pelo dinoflagelado Peridinium sp. (LAYBOURN-PARY, 1992, DOLAN; PÉREZ, 2000 e STOECKER, 1999),

A mixotrofia é uma estratégia alimentar importante para os organismos em ambientes caracterizados por baixas concentrações de alimento ou alta competição (REGALI-SELEGHIM, 2001), condizendo com o que foi encontrado no sistema estudado, sendo caracterizado como um corpo aquático oligotrófico, com menor disponibilidade de nutrientes e, conseqüentemente, menor concentração de clorofila a. Tais características podem indicar a existência de um controle do tipo "bottom up" em relação aos organismos que dependem do suprimento algal para se alimentar e controle do tipo "top-down" sobre os organismos que possuem menor habilidade de "capturar" estes escassos recursos, como os especialistas fagotróficos, bem como, os especialistas autotróficos que sofrem pressão de predação pelos níveis tróficos superiores (rotíferos, cladóceros e copépodos).

Sendo assim, as diferenças sazonais nos valores de densidade e biomassa dos tipos nutricionais dos protozoários ciliados e do dinoflagelado Peridinium sp. verificados em amostras de água da Represa das Antas pode estar refletindo a limitada disponibilidade e qualidade de fontes de alimento nesse corpo aquático. 


\subsubsection{Variação Sazonal e Espacial dos protozoários ciliados, do dinoflagelado Peridinium sp., do bacterioplâncton e da biomassa fitoplanctônica na Represa das Antas}

O padrão de distribuição horizontal dos organismos planctônicos em ecossistemas aquáticos pode ser explicado por diferentes fatores, dentre os quais destacam-se as forças advectivas, as variáveis limnológicas abióticas, os padrões de comportamento dos organismos e as relações biológicas (BINI et al. 1997).

$\mathrm{Na}$ Represa das Antas, um ambiente oligotrófico e ligeiramente ácido, foram identificados em amostras de água oito gêneros de protozoários ciliados pertencendo as Classes Peritrichia (Campanella umbellaria e Vorticella sp.), Prostomatida (Urotricha sp.), Gymnostomatida (Mesodinium sp., Monodinium sp. Paradileptus elephantiuns e Enchelys sp.) e Oligotrichia (Strombidium sp.), bem como, um gênero de dinoflagelado pertencente a Classe Phytomastigophora (Peridinium sp.).

Os ciliados Strombidium sp., Campanella umbellaria e Enchelys sp., podem ser considerados organismos persistentes na Represa das Antas (chamados kestrategistas), uma vez que, apresentaram as maiores freqüências de ocorrência ao longo de todo o período de estudo, ou seja, respectivamente, valores de 78,95\%, 52,63\% e 47,37\%. Provavelmente, estes resultados podem ser atribuídos as habilidades competitivas desses gêneros, a resistência à predação, bem com, a tolerância a estresses físicos e químicos, contribuindo para a permanência destes organismos no ambiente (BOSSOLAN; GODINHO, 2000). Os gêneros de ciliados Vorticella sp., Urotricha sp., Mesodinium sp., Monodinium sp., Paradileptus elephantinus detectados na Represa das Antas, podem ser considerados organismos "menos comuns" ou r-estrategistas. De acordo com Bossolan; Godinho (2000) os r-estrategistas são aqueles menos freqüentes no ambiente e que têm seu aparecimento muitas vezes regulado por florescimentos de organismos planctônicos, como, por exemplo, as algas ou bactérias, que são sua fonte de alimento, "driblando" a habilidade competitiva das espécies kestrategistas.

Dentre as Classes de organismos planctônicos detectadas em amostras de água da Represa das Antas, os organismos pertencentes às Classes Oligotricha e 
Phytomastigophora foram os dominantes em relação aos valores de biomassa e de densidade registrados.

Diferentemente do presente estudo, Packroff (2000) detectou, nas águas de um lago ácido ( $\mathrm{pH}$ variando de 4,5-6,0) e com baixa concentração de nutrientes (Lago Cospuden, Alemanha), que as Classes Prostomatida (Urotricha sp.) e Peritrichia (Vorticella sp.) foram dominantes. Weisse; Stadler (2006) relatam que as espécies de ciliados do gênero Urotricha sp. apresentam tolerância variável em relação aos valores de $\mathrm{pH}$ nos corpos aquáticos, o que influência a sua distribuição.

Em lagos ácidos da Flórida (EUA), Beaver; Crisman (1981) também verificaram a presença da Classe Oligotrichia em amostras de água, cujos valores de $\mathrm{pH}$ se encontravam tanto acima como abaixo de 5,0. De acordo com os autores, a disponibilidade de alimento, aliada aos fatores físicos e químicos dos lagos exerceram influência significativa na distribuição dos ciliados. Beaver; Crisman, Bienert (1998) sugeriram que a maior abundância dos oligotrichas em lago oligotrófico em comparação ao eutrófico, estava relacionada à capacidade dos organismos de utilizar tanto o metabolismo heterotrófico como o autotrófico.

Os gêneros de protozoários ciliados (Strombidium sp., Monodinium sp., Mesodinium sp. e Vorticella sp.) registrados na Represa das Antas, um ambiente oligotrófico, também foram registrados por Gomes; Godinho (2003) em amostras de água do Lago Monte Alegre-SP, um ambiente eutrófico.

Graham et al. (2004), estudando a dinâmica sazonal das populações de protozoários e algas em um corpo aquático ácido e oligotrófico (Crystal Bog Lake, Wisconsin) verificaram que, entre os gêneros de algas e protozoários encontrados, os dinoflagelados e os oligotrichas, respectivamente, foram dominantes, concordando com os resultados do presente estudo. Estes autores consideraram que a dominância dos dinoflagelados esteve relacionada ao estado de trofia do ambiente.

Os valores de biomassa dos protozoários ciliados registrados em amostras de água da Represa das Antas variaram de $0,8 \mu \mathrm{g} C \cdot 10^{-3} \cdot \mathrm{L}^{-1}$ a $1213 \mu \mathrm{g} \mathrm{C} \cdot 10^{-3} \cdot \mathrm{L}^{-1}$. Tais valores estiveram de acordo com os observados na literatura para ambientes oligotróficos e mesotróficos. Auer; Elzer; Arndt (2004) estudando lagos com diferentes graus de trofia na Alemanha, verificaram valores de biomassa de protozoários ciliados variando de $13 \mu \mathrm{g} \mathrm{C} .10^{-3} \cdot \mathrm{L}^{-1}$ a $28 \mu \mathrm{g} \mathrm{C} .10^{-3} \cdot \mathrm{L}^{-1}$ em lago 
mesotrófico. Carrick (2005) estudando a comunidade planctônica do Lago Michigan (EUA), detectou valores médios de biomassa de protozoários heterotróficos e de protozoários fototróficos variando de $20 \mu \mathrm{g} \mathrm{C} .10^{-3} \cdot \mathrm{L}^{-1}$ a $23 \mu \mathrm{g}$ C. $10^{-3} . L^{-1}$ e de $0 \mu \mathrm{g} \mathrm{C} \cdot 10^{-3} . L^{-1}$ a $20 \mu \mathrm{g} \mathrm{C} .10^{-3} . \mathrm{L}^{-1}$, respectivamente.

Os valores de densidade dos protozoários ciliados registrados em amostras de água da Represa das Antas variaram de $0,003 \cdot 10^{3}$ ind.$L^{-1}$ a $0,089 \cdot 10^{3}$ ind.$L^{-1}$. Graham et al. (2004) verificou valores de densidade de protozoários variando de $17.10^{3}$ ind. $\mathrm{L}^{-1}$ a $377.10^{3}$ ind. $\mathrm{L}^{-1}$ no lago oligotrófico Cristal (Madson - Wisconsin). Dolan et al. (2002) verificou valores de densidade dos ciliados Tintinídeos e Oligotrichas, na região leste do mar Mediterrâneo (considerada como oligotrófica), menor que 40 ind. $L^{-1}$ e menor que $10^{3}$ ind. $L^{-1}$, respectivamente. Carrick (2005) estudando a comunidade planctônica do Lago Michigan (EUA), detectou valores de densidade de protozoários ciliados variando de $4.10^{3}$ ind. $\mathrm{L}^{-1}$ a $17.10^{3}$ ind. $\mathrm{L}^{-1}$. Segundo o mesmo autor, tais valores eram similares àqueles informados em outros ambientes oligo e oligo-mesotróficos. Sendo assim, os valores de densidade de protozoários detectados nos trabalhos acima citados apresentaramse superiores aos valores de densidade registrados nas amostras de água da Represa das Antas.

Os menores valores verificados para a densidade (julho, outubro e fevereiro) e a biomassa (fevereiro) dos protozoários ciliados ocorreram em amostras de água coletadas no ponto P41. Para as amostras de água procedentes do ponto $P 41$, nos meses de julho e fevereiro, também foi detectada a maior freqüência de valores dos elementos químicos (fluoreto, manganês, zinco e sulfato) acima dos limites previstos na Resolução 357 do Conama (CONAMA, 2005) e elevados valores de dureza da água. De acordo com os resultados de correlação de Pearson, foi verificada correlação negativa entre as variáveis químicas fluoreto ($0,45)$, manganês $(r$ moderada $=-0,58)$, zinco $\left(r_{\text {moderada }}=-0,49\right)$, sulfato $\left(r_{\text {forte }}=-0,85\right)$, dureza $(r$ forte $=-0,85)$ e os valores de densidade dos ciliados registrados em amostras do ponto P41 (julho e fevereiro). Esse tipo de correlação também foi registrado entre os valores de biomassa dos ciliados em relação às concentrações de fluoreto $(r=-0,41)$, manganês $(r=-0,41)$ e zinco $(r=-0,43)$ para o ponto $\mathrm{P} 41$ (fevereiro).

A relação acima citada é um indicativo de que o lançamento dos efluentes tratados procedentes da UTM-INB, na Represa das Antas, esteja causando 
possíveis alterações na comunidade de protozoários ciliados. Os ciliados são organismos sensíveis a alterações ambientais (MADONI, 1993, LUGO et al. 1991, DIAS et al. 1999, MADONI, 2005) e eficientes bioindicadores de poluição ambiental, tanto orgânica (MADONI, 1993, LUGO et al. 1991, LEE et al. 2004, MADONI, 2005) quanto inorgânica (DIAS et al. 1999, MADONI; ROMEO, 2006).

Madoni, Esteban, Gorbi (1992) determinaram que uma concentração em torno de $2 \mathrm{mg} \cdot \mathrm{L}^{-1}$ de zinco, causou efeito tóxico agudo em espécies de protozoários (Aspidisca cicada, Colpidium campylum e Uronema nigricans) ciliados. Tal valor esteve próximo ao encontrado no ponto P41 em fevereiro de 2007 (zinco = 2,03 $\left.\mathrm{mg} \cdot \mathrm{L}^{-1}\right)$. Estudos sobre os efeitos da poluição por metais em ambientes aquáticos têm revelado alterações na comunidade protozooplanctônica. Boenigk; Wiedlroither; Pfandl (2005) reportaram aumento na atividade natatória e inibição alimentar de protozoários ciliados e atribuíram esse comportamento a efeitos de baixa toxicidade dos metais cádmio e mercúrio. Lê Jeune et al. (2007) estudando os efeitos do sulfato de cobre sobre a diversidade e a estrutura da comunidade planctônica microbiana pertencente ao chamado "elo microbiano" (picoplâncton autotrófico e heterotrófico, flagelados pigmentados e não pigmentados e ciliados) do Lago Pontalage (Limousin, França), verificaram diminuição na diversidade e nos valores de biomassa dos organismos pigmentados (picofitoplâncton e flagelados pigmentados), ausência de efeitos na biomassa e diversidade de flagelados heterotróficos e significativa redução na biomassa dos ciliados, sendo que os ciliados nanoplanctívoros (se alimentam de nanoplâncton) e mixotróficos apresentaram-se mais sensíveis às elevações nas concentrações de sulfato de cobre na água.

De um total de cinco amostragens realizadas, em duas delas, os maiores valores de densidade e de biomassa (outubro e fevereiro) dos protozoários ciliados foram detectados em amostras de água coletadas no ponto Cab. Nenhum outro ponto de amostragem apresentou concomitantemente essa freqüência de valores elevados de densidade e biomassa de protozoários ciliados. No ponto Cab foi detectada a menor freqüência de valores (17\%) das variáveis químicas acima dos limites previstos na Resolução 357 do Conama (CONAMA, 2005), quando comparado aos resultados obtidos nos demais pontos de amostragem avaliados. Tal fato indica melhor qualidade da água na Represa das Antas no ponto Cab, frente aos possíveis efeitos tóxicos dos agentes químicos sobre os protozoários 
ciliados. Além disso, excetuando-se os resultados obtidos no mês de julho, as amostras de água coletadas no ponto Cab apresentaram os maiores valores para densidade do dinoflagelado Peridinium sp., refletindo na maior disponibilidade de alimento para os ciliados. O gênero de protozoário predominante no ponto Cab, nos meses de outubro e fevereiro, foi o ciliado Strombidium sp., caracterizado por se alimentar de diatomáceas, algas e bactérias (FOISSNER; BERGER; SCHAUMBURG, 1999). Essa relação foi confirmada pela forte correlação positiva entre os valores de densidade de Peridinium sp. e os valores de biomassa ( $r=$ $0,99)$ e densidade $(r=0,70)$ do ciliado Strombidium sp.

Os valores de biomassa do dinoflagelado Peridinium sp. registrados em

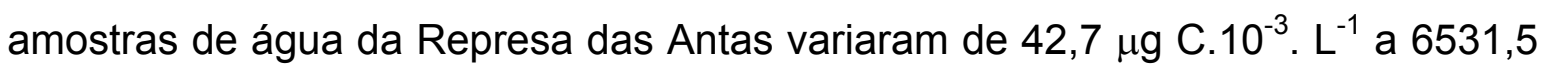
$\mu \mathrm{g} \mathrm{C} .10^{-3} . \mathrm{L}^{-1}$, que apresentaram-se elevados quando comparados a outros valores detectados em ambientes aquáticos. Bouvier; Becquevort; Lancelot (1998) estudando diferentes pontos de amostragem que apresentavam graus de trofia variando de eutrofico à oligotrófico na costa do Mar Negro, detectaram valores médios de biomassa para dinoflagelados mixotróficos variando de $0,54 \mu \mathrm{g} \mathrm{C.10^{- }}$ ${ }^{3} . \mathrm{L}^{-1}$ a $11,82 \mu \mathrm{g} \mathrm{C} .10^{-3} \cdot \mathrm{L}^{-1}$. Auer; Elzer; Arndt (2004) estudando lago mesotrófico na Alemanha verificaram valores de biomassa de flagelados heterotróficos variando de $1,0 \mu \mathrm{g} \mathrm{C} \cdot 10^{-3} \cdot \mathrm{L}^{-1}$ a $5 \mu \mathrm{g} \mathrm{C} \cdot 10^{-3} \cdot \mathrm{L}^{-1}$.

Os valores de densidade do dinoflagelado Peridinium sp. registrados em amostras de água da Represa das Antas variaram de $0,69.10^{3}$ ind $L^{-1}$ a 79,38.10 ind.$L^{-1}$. Graham et al. (2004) verificou valores de densidade dos dinoflagelados Peridinium cinctum e Peridinium limbatum variando de $1.10^{3}$ ind. $\mathrm{L}^{-1}$ a $20.10^{3}$ ind. $\mathrm{L}^{-}$ 1 e de $1.10^{3}$ ind. $L^{-1}$ a $1800.10^{3}$ ind. $L^{-1}$, respectivamente, no lago oligotrófico Cristal (Madson - Wisconsin). Carrick (2005) estudando a comunidade planctônica do Lago Michigan (EUA), detectou valores de densidade do dinoflagelado Peridinium inconspicuum variando de $100.10^{3}$ ind $\mathrm{L}^{-1}$ a $3000.10^{3}$ ind. $\mathrm{L}^{-1}$.

No presente estudo, os menores valores médios de densidade e de biomassa do dinoflgelado Peridinium sp. foram verificados em amostras de água coletadas no ponto $\mathrm{P} 14 \mathrm{~F}$, com exceção dos valores de biomassa registrados para o dinoflagelado Peridinium sp. em amostras de água do mês de fevereiro. Excetuando-se os meses de janeiro e abril, onde os valores de transparência da água demonstraram a ausência de radiação solar no ponto $\mathrm{P} 14 \mathrm{~F}$, moderadas 
correlações negativas entre a densidade e a biomassa do Peridinium sp. e os valores de clorofila $c(r=-0,56)$ no ponto P14F, podem indicar que este dinoflagelado, provavelmente estaria utilizando o metabolismo mixotrófico, na região hipolimnética da represa. De acordo com Stoecker (1999), muitas espécies de dinoflgelados mixotróficos primeiramente utilizam o fototrofismo, mas utilizam o fagotrofismo para suprir a deficiência de nutrientes inorgânicos e aumentar sua taxa de crescimento. Sendo assim, a ausência de luz levou o dinoflagelado Peridinium sp. a utilizar provavelmente a fagotrofia.

Fortes correlações positivas foram verificadas tanto para os valores de densidade quanto biomassa de Peridinium sp. em relação aos valores de sólidos em suspensão ( $r=0,88$ e $r=0,90$; respectivamente) no ponto P14F. Provavelmente, pode ter ocorrido ressuspensão de partículas do sedimento contendo fontes de alimento, a exemplo de células bacterianas, uma vez que, este dinoflagelado também é um hábil bacterívoro (GRAHAM et al. 2004, LAYBOURNPARRY, 1992, GONZÁLEZ, 1999, HAHN; MOORE; HÖFLE, 1999). Esta hipótese pôde ser suportada pela verificação de fortes correlações negativas entre os valores de densidade $(r=-0,93)$ e de biomassa $(r=-0,97)$ do Peridinium sp. e os valores de densidade bacteriana observados em amostras de água coletadas no ponto P14F. De acordo com Sonntag et al. (2006), tal correlação indica pressão de predação tipo top-down sobre as células bacterianas.

O maior valor de densidade para o dinoflagelado Peridinium sp. foi determinado em amostra de água coletada no ponto Cab, em outubro, e esteve positivamente correlacionado com as concentrações de oxigênio dissolvido na água $(r=0,79)$, com os valores de temperatura da água $(r=0,90)$ e com as concentrações de clorofila $c(r=0,60)$. Provavelmente, este organismo, utilizando o metabolismo autotrófico possa ter contribuído para os valores de concentração de oxigênio dissolvido e os valores de clorofila $c$ na água, refletidos através das correlações obtidas.

O maior valor de biomassa para o dinoflagelado Peridinium $\mathrm{sp}$. foi registrado em amostra de água coletada no ponto P14S, em fevereiro. Neste mesmo mês, o maior valor de clorofila $c$ também foi registrado no ponto P14S. A clorofila $c$ é um dos pigmentos constituintes dos dinoflagelados (STRAIN; MANNING; HARDIN, 1943). Houve forte correlação positiva entre os valores de clorofila $c$ e os valores da biomassa do dinoflagelado Peridinium sp. $(r=0,79)$ para o mês de fevereiro, 
bem como moderada correlação negativa com o valor de densidade bacteriana ( $r$ $=-0,50$ ) para o mês de fevereiro, sugerindo que este dinoflagelado provavelmente poderia estar utilizando o metabolismo mixotrófico, alimentando-se de células bacterianas e realizando a fotossíntese.

Os valores de densidade bacteriana procedentes de amostras de água da Represa das Antas variaram de $1,0.10^{9}$ ind. $\mathrm{L}^{-1}$ a $9,0.10^{9}$ ind. $\mathrm{L}^{-1}$ ao longo de todo período de estudo avaliado. Tais valores apresentaram-se menores quando comparados aos verificados por Araújo; Godinho (2008) que encontraram valores de densidade das células bacterianas variando de $2,67.10^{10}$ ind. $\mathrm{L}^{-1}$ a $5,1.10^{10}$ ind. $\mathrm{L}^{-1}$ em um sistema fluvial-lagunar mesotrófico, localizado a leste do estado do Rio Grande do Norte. Por outro lado, os valores de densidade bacteriana verificados na Represa das Antas foram elevados quando comparados aos registrados por Nakano; Ban (2003) no lago oligotrófico Toya (Hokkaido, Japão). Esses autores registraram valores de densidade bacteriana variando de $1,1.10^{7}$ ind. $\mathrm{L}^{-1}$ a $8,0.10^{8}$ ind. $\mathrm{L}^{-1}$.

De acordo com Pedrós-Alió; Guerrero (1994), sistemas aquáticos produtivos podem alcançar valores de densidade bacteriana de $10^{10}$ ind. $\mathrm{L}^{-1}$, enquanto que, sistemas aquáticos extremamente oligotróficos podem apresentar valores de densidade bacteriana em torno de $10^{8}$ ind. $\mathrm{L}^{-1}$. Os resultdos para densidade bacteriana em amostras de água analisadas no presente estudo apresentaram faixa de variação intermediária quando comparado aos resultados obtidos pelos autores acima citados.

Jugnia et al. (1998) relataram que a abundância bacteriana registrada em um lago municipal apresentando um avançado estágio de eutroficação (localizado na cidade de Yaoundé, Camarões - África Central) esteve entre os maiores detectados em sistemas pelágicos $\left(0,8 \cdot 10^{11}\right.$ ind. $L^{-1}$ a $2,10^{11}$ ind. $\left.L^{-1}\right)$.

O bacterioplâncton proveniente de amostras de água do ponto P41 da Represa das Antas apresentou os dois maiores valores de densidade nos meses de abril e outubro. Esse tipo de comportamento não foi verificado para os valores de densidade dos ciliados e do dinoflagelado Peridinium sp., ao longo de todo o período avaliado. Tal resultado pode ser atribuído a menor pressão de predação (tipo top-down) exercida pelos ciliados e dinoflagelados sobre o bacterioplâncton, uma vez que, não foram verificadas fortes correlações entre os valores de densidade dos protozoários ciliados $(r=0,5)$, densidade do dinoflagelado 
Peridinium sp. ( $r=-0,3)$ com os valores de densidade do bacterioplâncton em amostras de água do ponto P41.

Além disso, a forte correlação positiva verificada $(r=0,94)$ entre os valores de densidade bacteriana e biomassa fitoplanctônica no mês de abril, sugere que o bacterioplâncton poderia estar utilizando a matéria orgânica excretada pelos organismos fotossintetizantes como fonte de nutriente (YANNARELL; TRIPLETT 2005, DeWEVER et al. 2005, TANAKA et al. 2007, COTNER; BIDDANDA, 2002, ZINABU; TAYLOR, 1997).

Os menores valores de densidade bacteriana verificados em amostras de água provenientes dos pontos P41 (julho), P14S e P14F (fevereiro) podem estar relacionados à pressão de predação exercida pelos níveis tróficos superiores, pela menor disponibilidade de alimento (matéria orgânica e nutriente) e pelas características físicas e químicas do ambiente. Fortes correlações negativas foram registradas entre os valores de densidade bacteriana do ponto P14F e os valores de biomassa do dinoflagelado Peridinium sp. $(r=-0,97)$, bem como, para os valores de densidade do Peridinium sp. $(r=-0,93)$. Em relação aos resultados obtidos no mês de fevereiro, observou-se moderada correlação negativa entre a densidade bacteriana em amostras de água da Represa das Antas e a biomassa do dinoflagelado $(r=-0,49)$. Por outro lado, houve forte correlação negativa $(r=-$ 0,87 ) entre a densidade bacteriana e os valores de densidade do Peridinium sp. determinados no mês de julho. Tais correlações indicam possível relação de predação do dinoflagelado Peridinium sp. sobre o bacterioplâncton.

As correlações negativas observadas entre os valores de densidade bacteriana em amostras de água provenientes da Represa das Antas e os valores de biomassa fitoplanctônica no mês de fevereiro $(r$ moderada $=-0,51)$ e julho $\left(r_{\text {forte }}=\right.$ 0,83 ) demonstram que a limitação na disponibilidade de alimento pode ter sido um dos fatores controladores da densidade bacteriana neste corpo aquático, já que a matéria orgânica excretada pelos organismos fitoplanctônicos pode contribuir como fonte de nutrientes para as células bacterianas (YANNARELL; TRIPLETT 2005, DeWEVER et al. 2005, TANAKA et al. 2007, COTNER; BIDDANDA, 2002).

Como anteriormente já discutido, a maior freqüência de valores das variáveis químicas, nos meses de julho/06 e fevereiro/07, acima dos limites estabelecidos pela Resolução 357 do Conama (CONAMA, 2005), registrada nas amostras de água provenientes do ponto P41 (33\%) e a jusante desse, indicaram condições 
ambientais adversas. Tais condições, provavelmente interferiram nos valores de densidade de organismos aquáticos no ambiente. A influência das elevadas concentrações de elementos químicos sobre o bacterioplâncton pôde ser verificada pelas fortes correlações negativas entre os valores de densidade bacteriana, registrados em amostras de água do ponto P41 e os valores de sulfato $(r=-0,75)$ e dureza $(r=-0,71)$, bem como, a jusante do P41, ou seja, nos pontos P14S e P14F para a variável manganês ( $r=-0,83)$. Mudryk; Dwulit (2004), estudando os efeitos tóxicos de diferentes concentrações de mercúrio sobre a abundância e a atividade respiratória das bactérias no Lago Gardno (Polônia) verificaram que os íons de mercúrio em concentrações menores que $10 \mathrm{mg} \cdot \mathrm{dm}^{-3}$ já exibiam efeitos tóxicos sobre a abundância e a taxa de captura de oxigênio do bacterioplâncton no Lago Gardno. Contrariamente ao observado no estudo citado acima e na Represa das Antas, Grandlic et al. (2006) estudando os possíveis efeitos tóxicos do chumbo sobre a estrutura das comunidades bacterianas do sedimento do Lago Rush (USA), não verificaram nenhuma relação entre as concentrações de chumbo no sedimento $\left(59 \mathrm{mg} \cdot \mathrm{L}^{-1}\right)$ e a abundância das bactérias heterotróficas, concluindo que o chumbo não causou alterações na estrutura da comunidade bacteriana desse lago.

Ainda em relação ao ponto P14S, forte correlação positiva foi verificada entre o valor médio de densidade bacteriana e o valor médio de densidade dos protozoários ciliados $(r=0,85)$. Essa correlação sugere que os gêneros de protozoários ciliados presentes nesse local poderiam estar utilizando as bactérias como uma fonte alimentar. Tal hipótese pode ser suportada pela preferência alimentar dos gêneros de ciliados detectados no ponto P14S, bactérias/flagelados (Urotricha sp.), bactérias/algas (Vorticella sp.), Omnívoro (Paradileptus elephatinus e Mesodinium sp.) e R-predador (Monodinium sp), que são considerados potenciais predadores do bacterioplâncton (BICK, 1972, FOISSNER; BERGER; SCHAUMBURG, 1999). Protozoários bacterívoros ou fagotróficos são importantes nas redes alimentares pelágicas, predando cerca de 80 a $100 \%$ da produção bacteriana diária, sendo considerados os principais responsáveis pela sua mortalidade e, portanto, uma importante força seletiva para as bactérias aquáticas (JÜRGENS et al. 1999; GONZÁLEZ et al. 1990; SHERR et al. 1992; MATZ; JÜRGENS, 2001 e 2005; CORNO; JÜRGENS, 2006). 
Os resultados ora apresentados estiveram de acordo com aqueles registrados por Kisand; Nõges (2004) que consideraram os ciliados como os principais controladores da biomassa bacteriana em um lago eutrófico na Estônia. Similarmente, Gomes; Godinho (2003) verificaram que a densidade e biomassa das espécies protozooplanctônicas Monodinium balbiani, Holophryra cf. discolor, Mesodinium pulex, Strombidium sp. e Vorticella $\mathrm{sp}$ estiveram associados a densidade bacteriana. De acordo com Bossolan; Godinho (2000), ciliados Mesodinium sp., Paradileptus sp., Strombidium sp. e Uroleptus sp presentes na lagoa do Infernão (São Paulo) se alimentavam das altas densidades de bactérias presentes nesse sistema aquático.

De um total de 19 amostras coletadas em diferentes pontos de amostragem ao longo do presente estudo, a maior freqüência de amostras positivas para a biomassa fitoplanctônica (valor de biomassa fitoplanctônica maior do que 0,0 $\mu \mathrm{g}$ C. $10^{-3} \cdot \mathrm{L}^{-1}$ ) registrada em amostra de água na Represa das Antas, foi detectada no ponto P41, ou seja, em 3 amostras (15,8\%).

Tais valores não apresentaram correlações que pudessem explicar a freqüência de ocorrência descrita acima, em relação às seguintes variáveis: temperatura da água, oxigênio dissolvido e $\mathrm{pH}$. Talvez tais variáveis não tenham sido fatores limitantes para a presença da comunidade fitoplanctônica. Os baixos valores de densidade e biomassa dos protozoários ciliados registrados frequentemente no ponto P41, quando comparado aos resultados obtidos nas demais amostras de água analisadas, evidenciam a possibilidade de ocorrência, de menor pressão de predação dos ciliados sobre a comunidade fitoplanctônica, sendo suportada pela forte correlação positiva $(r=0,8)$ identificada entre estes grupos para o ponto $\mathrm{P} 41$.

Neste estudo não foi detectada a presença de biomassa fitoplanctônica em amostras de água procedentes do ponto $\mathrm{P} 14 \mathrm{~F}$, durante todo o período avaliado. Para os meses de janeiro e abril tal resultado era esperado, uma vez que, os valores de transparência da água foram respectivamente, 1,8 e 1,6 m, evidenciando a falta de radiação solar na região hipolimnética da Represa das Antas. No restante do período avaliado, outros fatores devem ter influenciado os resultados obtidos para os valores de biomassa fitoplanctônica no ponto P14F, ou seja, valores iguas a zero. Tundisi et al. (2004) também verificaram que os valores para as concentrações de clorofila a e a densidade das comunidades 
fitoplanctônicas no Reservatório Carlos Botelho (sudeste do Estado São Paulo, Brasil) foram mais elevados nas camadas de água mais superficiais da represa. Tal fato indica que, a menor incidência de radiação solar na região hipolimnética dos corpos d'água provavelmente possue um importante papel nos valores de concentração de clorofila no ambiente, bem como na distribuição da comunidade fitoplanctônica.

\subsubsection{1 Índice de Saprobidade}

De acordo com os resultados obtidos em amostras de água coletadas na Represa das Antas, ao longo de todo o período de estudo, esse reservatório foi classificado como beta-mesosapróbico. Segundo Foissner; Berger; Hohmann (1992) ambientes classificados como beta-mesosapróbico apresentam uma zona onde há decomposição de compostos, próximos de um estado de mineralização e um baixo déficit de oxigênio. Uma grande variedade de protistas, plantas e animais ocorrem em números consideráveis, com qualidade de água Classe II.

Somente para os valores médios de índice de saprobidade verificados em amostras de água provenientes da Represa das Antas no mês de janeiro, houve alteração neste padrão e o reservatório foi classificado como alfa-mesosapróbico. Segundo Foissner; Berger; Hohmann (1992), tal classificação indica ambiente que possui uma região oxigenada e um início de remineralização, possui muitas espécies, sendo bactérias e protistas dominantes, com qualidade da água Classe III.

Dentre os protozoários ciliados detectados na Represa das Antas apresentando valores de Indice de Saprobidade por espécie (FOISSNER, 1992) elevado, destacamos a Campanella umbellaria registrada no mês de janeiro (IS = 2,8). Além de apresentar elevado valor de Indice de Saprobidade por espécie, esse ciliado também apresentou o maior valor médio de biomassa no mês de janeiro. Portanto, foi considerado o principal ciliado responsável pelo aumento no valor do Índice de Saprobidade neste reservatório neste mês. De acordo com Bick (1972) a Campanella umbellaria ocorre em corpos aquáticos lênticos e lóticos moderadamente poluídos e de classificação saprobiológica de beta- 
mesosapróbica à alfa-mesosapróbica, concordando com o verificado na Represa das Antas.

Os resultados obtidos para a Represa das Antas frente ao Índice de Estado Trófico e o Índice de Saprobidade concordaram entre si. De acordo com o valor de Índice de Saprobidade (beta-mesosapróbico), esse reservatório foi classificado como corpo de água limpo e pouco poluído, frente à presença de compostos orgânicos (PANTLE; BUCK, 1955); e, de acordo com o valor de Indice de Estado Trofico (oligotrófico) a Represa das Antas apresentou-se como um corpo de água limpo, de baixa produtividade, em que não ocorrem interferências indesejáveis sobre os usos da água segundo a especificação descrita para o estado de trofia (TOLEDO et al. 1983).

\subsubsection{2 Índice de Diversidade}

No presente estudo os resultados de Índice de Diversidade registrados mostraram que houve baixa diversidade de protozoários ciliados quando comparado a outros estudos também realizados em ambientes oligotróficos (JYOTHIBABU et al. 2008, GRAHAM et al. 2004, DOLAN et al. 2002).

Nos meses de julho e fevereiro foram verificados, comparativamente, as maiores possibilidades para a ocorrência de toxicidade química na Represa das Antas, sobre os protozoários ciliados, uma vez que houve queda nos valores de índice de diversidade em amostras de água provenientes do ponto P41 e a jusante desse.

Nesse contexto, pode-se considerar que os gêneros de protozoários ciliados presentes nos meses de julho (Strombidium sp. e Enchelys sp.) e fevereiro (Strombidium sp., Enchelys sp., Campanella umbellaria e Paradileptus elephantinus) no ponto P41 e a jusante desse, eram tolerantes a tais condições ambientais extremas.

O resultado da análise de correlação concordou com a hipótese acima, de que a maioria dos gêneros de ciliados presentes em fevereiro foram, provavelmente, resistentes aos elevados valores de concentrações de elementos químicos registrados. Houve baixa freqüência de ocorrência de correlação moderada entre os valores de biomassa registrados para os gêneros Enchelys sp. (10\%), 
Paradileptus elephantinus (37,5\%) e Campanella umbellaria $(22,2 \%)$ e os valores de variáveis físicas e químicas. Por outro lado, houve alta freqüência de ocorrência de correlação moderada, correlação forte ou muito forte entre os valores de biomassa registrados para os gêneros Enchelys sp. (90\%), Paradileptus elephantinus $(62,5 \%)$ e Campanella umbellaria $(77,8 \%)$ e os valores das variáveis biológicas. Tais resultados indicaram que as características físicas e químicas no sistema aquático apresentaram menor interferência para os gêneros de protozoários ciliados presentes nas amostras de água procedentes do ponto P41 e a jusante desse, no mês de fevereiro, quando comparadas à características bióticas.

Para o mês de julho, os valores de índice de diversidade, baseado nos valores de biomassa dos protozoários ciliados, apresentaram maior freqüência de ocorrência de correlações moderadas negativas com as variáveis físicas e químicas (75\%) quando comparado aos demais meses de estudo. Entretanto, tais correlações foram sempre moderadas e negativas não indicando forte influência das variáveis físicas e químicas sobre o índice de diversidade registrado no mês de julho.

Diferentemente, nos meses de janeiro, abril e outubro, os valores de índice de diversidade obtidos em amostras de água procedentes da Represa das Antas apresentaram elevada freqüência de ocorrência de fortes correlações com as variáveis físicas e químicas, ou seja, $66,6 \%$ para o mês de janeiro, 50\% em abril e $70 \%$ no mês de outubro. Sendo assim, pode-se sugerir que ocorreu baixa influência das variáveis físicas e químicas sobre a diversidade dos protozoários ciliados nos meses de julho e fevereiro, indicando provavelmente a existência de formas tolerantes as alterações físicas e químicas ocorridas nestes meses.

De acordo com Xu et al. (2005), que estudaram o lago Chaohu na China (lago raso com profundidade máxima de $6 \mathrm{~m}$ ), relacionaram a baixa diversidade de protozoários do ambiente estudado com poluição ambiental neste corpo aquático. De acordo com esses autores, a baixa riqueza de espécies na região oeste do lago, provavelmente resultou da entrada de um grande número de poluentes pela descarga vinda do Rio Nanfei. Foi enfatizado neste estudo, que situações estressantes, causadas pela presença de metais pesados, extrema poluição orgânica, alterações no $\mathrm{pH}$, flutuações na temperatura da água, ou ainda, 
mudanças agudas em outros fatores, geralmente reduzem o número de espécies e aumenta a concentração de formas de vida tolerantes. 


\section{CONCLUSÕES}

As principais conclusões obtidas no presente estudo foram as seguintes:

a) De acordo com os resultados obtidos para as variáveis físicas e químicas nas amostras de água procedentes da Represa das Antas, este corpo aquático apresentou valores de $\mathrm{pH}$ ligeiramente ácidos, bem como elevados valores de condutividade elétrica, dureza e a presença de elevadas concentrações dos elementos químicos fluoreto, manganês, zinco e sulfato, presentes em todos os pontos e períodos de amostragem avaliados. Tais valores estiveram relacionados à litologia e a precipitação na bacia hidrográfica, bem como aos efluentes lançados pela UTM-INB;

b) No mês de fevereiro, para amostras de água procedentes do ponto P41 e a jusante desse, ou seja, pontos P14S e P14F, o parâmetro lançamento de efluentes de mina de urânio, provavelmente, influenciou a ocorrência de alta freqüência de valores elevados de dureza, de condutividade, de fluoreto, de manganês, de zinco, de sulfato, bem como valor de $\mathrm{pH}$ ligeiramente ácido, em amostras da água na Represa das Antas;

c) Os maiores valores de dureza registrados em amostras de água procedentes do ponto P41 e a jusante deste, ou seja, pontos P14S e P14F, provavelmente, estiveram relacionados ao hidróxido de cálcio utilizado no sistema de tratamento de efluentes da UTM-INB, antes do lançamento desses para o meio ambiente;

d) A elevada freqüência de ocorrência, bem como os elevados valores de densidade e biomassa de organismos mixotróficos (Strombidium sp. e Peridinium sp.) registrados em amostras de água da Represa das Antas foram condizentes com o estado de trofia desse sistema aquático.

e) As variáveis condutividade elétrica, $\mathrm{pH}$ e as variáveis clorofila $b$, manganês, apresentaram, respectivamente, variação sazonal e espacial ao longo do período avaliado na Represa das Antas. Houve variação sazonal 
e espacial para as seguintes variáveis analisadas em amostras de água da Represa das Antas: temperatura da água, oxigênio dissolvido, dureza, fluoreto, sulfato, urânio, tório e densidade média total do dinoflagelado Peridinium sp.

f) De acordo com as varáveis avaliadas no presente estudo para a determinação de índice de estado trófico, sazonalmente, a Represa das Antas foi classificada como um corpo aquático oligotrófico, apresentando baixos valores médios de concentração de clorofila $a$, elevados valores médios de transparência da coluna d'água, bem como baixos valores médios de concentração de fósforo total, indicando a ausência de problemas relacionados à eutrofização, concordando com o resultado obtido para o Índice de Saprobidade que classificou este ecossistema aquático como beta-mesosapróbico.

g) No mês de fevereiro, para amostras de água procedentes do ponto P41 e a jusante desse, ou seja, pontos P14S e P14F, o parâmetro lançamento de efluentes de mina de urânio, provavelmente, influenciou a ocorrência de alta freqüência de valores elevados de dureza, de condutividade, de fluoreto, de manganês, de zinco, de sulfato, bem como valor de $\mathrm{pH}$ ligeiramente ácido, em amostras da água na Represa das Antas;

h) Os maiores valores de dureza registrados em amostras de água procedentes do ponto P41 e a jusante deste, ou seja, pontos P14S e P14F, provavelmente, estiveram relacionados ao hidróxido de cálcio utilizado no sistema de tratamento de efluentes da UTM-INB, antes do lançamento desses para o meio ambiente;

i) Os baixos valores de Índice de Diversidade registrados nesse corpo aquático, sazonalmente e espacialmente, provavelmente estiveram relacionados à condição de oligotrofia verificada neste corpo aquático, bem como a possíveis efeitos tóxicos do lançamento de efluentes de mina de urânio na Represa das Antas. 
j) De acordo com os valores de Índice de Diversidade registrados na Represa das Antas ao longo deste estudo, pôde-se concluir que houve a ocorrência de ciliados tolerantes às condições físicas e químicas em amostras de água procedentes do ponto P41 e a jusante deste.

k) A faixa de variação para os valores de densidade e biomassa dos protozoários ciliados e do dinoflagelado Peridinium sp., bem como para os valores de densidade do bacterioplâncton, registrados nas amostras de água da Represa das Antas, apresentaram-se condizentes a valores registrados em outros ambientes oligotróficos.

I) Os maiores valores de densidade e biomassa dos protozoários ciliados, a maior freqüência de ocorrência de maiores valores de densidade do dinoflagelado Peridinium sp., detectados no ponto Cab, estiveram relacionados à melhor qualidade química da água na Represa das Antas nesse ponto de amostragem.

m) O ponto P41 apresentou a maior ocorrência de menores valores médios de densidade e biomassa de protozoários ciliados e do dinoflagelado Peridinium sp. Provavelmente estes organismos foram mais sensíveis às características químicas dos efluentes lançados na Represa das Antas, uma vez que nesse local foi registrada a maior freqüência de ocorrência de compostos químicos acima dos limites previstos na Resolução 357 do CONAMA;

n) Dentre os protozoários ciliados registrados em amostras de água provenientes da Represa das Antas foram registrados alguns gêneros que apresentam características que podem estar relacionadas às condições de oligotrofia do ambiente, bem como a estresse frente a agentes químicos: predomínio de ciliados pequenos que apresentam reduzido tempo de geração (Strombidium sp. e Enchelys sp.), predomínio de ciliados com habilidade para saltar e escapar da predação (Strombidium sp.) , a presença de grandes ciliados menos vulneráveis à predação (Campanella 
umbellaria e Paradileptus elephantinus), bem como organismos apresentando metabolismo mixotrófico (Peridinium sp. e Strombidium sp.);

o) Os maiores valores de densidade de células bacterianas e freqüência de amostras positivas para biomassa fitoplanctônica, registrados em amostras de água do ponto $\mathrm{P} 41$, provavelmente, estiveram relacionados à menor pressão de predação exercida pelos protozoários ciliados e pelo dinoflagelado Peridinium sp. sobre o bacterioplâncton e o fitoplâncton.

p) Na Represa das Antas a predominância de densidade e biomassa de protozoários ciliados do tipo nutricional ki/alg/bac, seguido dos omnívoros mostraram que os tipos nutricionais presentes foram característicos de ambientes extremos e/ou oligotróficos.

q) Foi verificada a dominância de organismos planctônicos mixotróficos na Represa das Antas e os principais representantes em termos de valores de densidade e de biomassa, foram o protozoário ciliado Strombidium sp. e o dinoflagelado Peridinium sp..

r) O dinoflagelado Peridinium sp. apresentou maiores valores médios de densidade e de biomassa ao longo de todo o período avaliado quando comparado aos valores médios de densidade e de biomassa registrados para protozoários ciliados neste estudo. 


\section{REFERÊNCIAS BIBLIOGRÁFICAS}

ABE, D. S.; ARANTES, J. D.; MINOTI, R. T.; PETRACCO, P.; SILVA, W. M.; TUNDISI, J. G. O processo de eutrofização artificial na represa do Lobo (Itirapina, SP): condições atuais e perspectivas futuras. In: SEMINÁRIO INTERNACIONAL REPRESA DO LOBO-BROA - 30 ANOS, 2000, São Carlos. Resumos. São Carlos: Escola de Engenharia de São Carlos, Universidade de São Paulo, 2000. p. 26.

ALMEIDA da SILVA, C.; TRAIN, S.; RODRIGUES, L. C. Phytoplankton assemblages in a Brazilian subtropical cascading reservoir system. Hydrobiologia, v. 537, p. 99-109, 2005.

ANNUAL BOOK OF ASTM STANDARDS. Analytical Methods (Spectroscopy; Chromatography; Computerized Systems). Philadelphia: American Society for Testing and Materials, 1980. Part 42, p. 646.

ARANTES, Jr. J. D.; RIETZLER, A. C.; ROCHA, O.; REGALI-SELEGHIM, M. H. Caracterização das populações de protozoários (Ciliophora e Rhizopoda) no Reservatório de Salto Grande, Americana, SP. In: SPINDOLA, E. L.; LEITE, M. A.; DORNFELD, C. B. Ecologia do Reservatório de Salto Grande, Americana, SP. São Carlos: Editora, 2004. p. 155-177.

ARAÚJO, M. F. F.; GODINHO, M. J. L. Seasonal and Spatial Distribution of Bacterioplankton in a Fluvial-lagunar System of a Tropical Region: Density, Biomass, Cellular Volume and Morphologic Variation. Brazilian Archives of Biology and Technology, v. 51, n. 1, p. 203-212, 2008.

AUER, B.; ELZER, U.; ARNDT. H. Comparasion of pelagic food webs in lakes along a trophic gradient and with seasonal aspects: influence of resource and predation. Journal of Plankton Research, v. 26, n. 6, p. 297-709, 2004.

AZAM, F.; FENCHEL, T.; FIELD, J. G.; GRAY, J. S.; MEYER-REIL, L. A.; THINGSTAD, F. The ecological role of water-columm microbes in the sea. Microbial Ecology Progress Series, v. 10, p. 257-263, 1982.

BARBIERI, S. M.; GODINHO-ORLANDI, M. J. L. Ecological studies on the planktonic protozoa of na eutrophic reservoir (Rio Grande Reservoir - Brazil). Hydrobiologia, v. 183, p. 1-10, 1989.

BARRETO, W. J.; ISHIKAWA, D. N.; SCARMINIO, I. S.; COSTA, J. D. S.; NORA, P. D. S.; SOARES, M. D. F.; NICOLAU, R. M.; GONÇALVE, A. C. E.; BARRETO, S. R. G. Fe, Mn, P and S speciation in sediments from the Capivara Hydroelectric (Usina Hidrelétrica de Capivara), dam lake (Brazil) as an indicator of anthropogenic influences. Clean-Soil Air Water, v. 36, n. 4, p. 353-359, 2008.

"ASSOCIAÇÃO BRASILEIRA DE NORMAS TÉCNICAS. NBR 6023: Informação e documentação: referências: elaboração. Rio de Janeiro, 2002. 
BEAVER, J. R.; CRISMAN, T. L. Acid precipitation and the response of ciliated protozoans in Florida lakes. Verhnilag International Venialegendi Limnology, $v$. 21, p. 353-358, 1981.

BEAVER, J. R.; CRISMAN, T. L.; BIENERT Jr., R. W. Distribution of planktonic ciliates in highly coloured subtropical lakes: comparison with clearwater ciliate communities and the contribution of myxotrophic taxa to total autotrophic biomass. Freshwater Biology, v. 20, p. 51-60, 1988.

BEAVER, J. R.; CRISMAN, T. L. The role of ciliated protozoa in pelagic freshwater ecosystems. Microbiology and Ecology, v. 17, p. 111-136, 1989.

BENEDETTO, J. S.; ALMEIDA, S. K.; GOMES, H. A.; VAZOLLER, R. F.; LADEIRA, A. C. Q. Monitoring of sulfate-reducing bacteria in acid water from uranium mines. Minerals Engeneering, v. 18, p. 1341-1343, 2005.

BEZERRA-NETO, J. F.; PINTO-COELHO, R. M. A morfometria e o estado trófico de um reservatório urbano: lagoa do Nado, Belo Horizonte, Estado de Minas Gerais. Maringá, v. 24, n. 2, p. 285-290, 2002.

BICK, H. Ciliated Protozoa. Germany: World Hearth Organization, 1972. p. 198.

BINI, L. M.; TUNDISI, J. G.; MATSUMURA-TUNDISI, T.; MATHEUS, C. E. Spatial variation of zooplankton groups in a tropical reservoir (Broa Reservoir, São Paulo State - Brazil). Hydrobiologia, v. 357, p. 89-98, 1997.

BIYU, S. A comparative study on planktonic ciliates in two shallow mesotrophic lakes (China): species composition, distribution and quantitatice importance. Hydrobiologia, v. 427, p. 143-153, 2000.

BOENIGK, J.; ARNDT, H. Bacterivory by heterotrophic flagellates, community structure and feeding strategies. Journal Antonie Van Leeuwenhoek, v. 81, p. 465-480, 2002.

BOENIGK, J.; WIEDLROITHER, A.; PFANDL, K. Heavy metal toxicity and bioavailability of dissolved nutrients to a bacterivorous flagellate are linked to suspended particle physical properties. Aquatic Toxicology, v. 71, p. 249-259, 2005.

BORSHEIM, K. Y.; BRATBAK, G. Cell volume to cell carbon conversion factors for a bacterivorous Monas sp. enriched from seawater. Marine Ecology, v. 36, p. 171-175, 1987.

BOSSOLAN, N. R. S.; GODINHO, M. L. Abundância numérica e composição do protozooplâncton na Lagoa do Infernão - SP. In: SANTOS, J. E.; PIRES, J. S. R. (Org). Estudos integrados em ecossistemas: Estação Ecológica de Jataí. São Carlos: Editora Rima, 2000. v. 2, p. 523-536.

BOUVIER, T.; BECQUEVORT, S.; LANCELOT, C. biomass and feeding activity of phagotrophic mixotrophs in the northewestern Black Sea during the summer 1995. Hydrobiologia, v. 363, p. 289-301, 1998. 
BURNS, C. W.; GALBRAITH, L. M. Relating planktonic microbial food web structure in lentic freshwater ecosystems to water quality and land use. Journal of Plankton Research, v. 29, n. 2, p. 127-139, 2007.

BRANDENBERGER, J.; LOUCHOUARN, P.; HERBERT, B.; TISSOT, P. Geochemical and hydrodynamic controls on arsenic and trace metal cycling in a seasonally stratified US sub-tropical reservoir. Applied Geochemistry, v. 19, p. 1601-1623, 2004.

BRASIL. Ministério do Meio Ambiente. Secretaria de Recursos Hídricos. Plano Nacional de Recursos Hídricos, Panorama e Estado dos Recursos Hídricos do Brasil. Brasília, D.F.: MMA, 2006. v. 1, 288 p.

BRASIL. Ofício n 050/SLC, de 27 de junho de 1997. Limites derivados para os pontos de lançamento de efluentes líquidos do Complexo Industrial de Poços de Caldas da Unidade de Tratamento de Minérios das Indústrias Nucleares do Brasil (UTM-INB). Rio de Janeiro, 1997.

BRASIL. Resolução No 357, de 17 de Março de 2005. Resolução do CONAMA para a classificação de águas de acordo com sua composição e os teores máximos de substâncias potencialmente prejudiciais. São Paulo. Legislação: Publicado no DOU de 03 de julho de 1986, p. 5-6, 2005.

BROCK, T. D. Biology of the microorganisms. 1. ed. New Jersey: Editora Prentice Hall, 1994. p. 909.

CAMPBELL, P. G. C. Biologically avaliable metals in sediments. NRCC Report 27694, Otawa, Canada, p. 15, 1988.

CAMPOS, M. B. Ocorrência e Flutuação de Acidithioobacillus spp. Em Efluentes de Mina de Urânio, Caldas - MG. 40 f. Trabalho de Conclusão de Curso (Monografia) - Centro Universitário Fundação de Ensino Octávio Bastos, São João da Boa Vista, São Paulo, 2006.

CARLSON, R. E. A trophic state index for lakes. Limnology and Oceanography, v. 22, p. 361 - 380. 1977.

CARRICK, J. H. An under-appreciated component of biodiversity in plankton communities: the role of protozoa in Lake Michigan (a case study). Hydrobiologia, v. 551, p. 17-32, 2005.

CHRISTOFOLETTI, A. Análise morfométrica das bacias hidrológicas do Planalto de Poços de Caldas - MG. 215 f. Tese (Livre Docência) - Faculdade de Filosofia, Ciências e Letras, Rio Claro, 1970.

CIPRIANI, M. Mitigação dos impactos sociais e ambientais decorrentes do fechamento definitivo de minas de urânio. 332 f. Tese (Doutorado) Faculdade de Engenharia, Universidade de Campinas, Campinas, 2002.

Colégio São Francisco. Escala Beaufort dos Ventos. Disponível em: <http://www.colegiosaofrancisco.com.br/alfa/ventos/escala-beaufort. >. Acesso em: 20 mai. 2008. 
CONTY, A.; GARCÍA-CRIADO, F. Changes in bacterial and ciliate densities with trophic status in Mediterranean shallow lakes. Hydrobiologia, v. 584, p. 327-335, 2007.

CORNO, G.; JÜRGENS, K. Direct and Indirect Effects of Protist Predation on Population Size Strutucture of a Bacterial Strain with High Phenotypic Plasticity. Applied and Environmental Microbiology, v. 72, n. 1, p. 78-86, 2006.

COTNER, J. B.; BIDDANDA, B. A. Small Players, Large Role: Microbial Influence on Biogeochemical Processes in Pelagic Aquatic Ecosystems. Ecosystems, v. 5, p. 105-121, 2002.

DABÊS, M. B. G. S.; FRANÇA, R. C.; GOMES, M. C. S.; JUNQUEIRO, M. V.; ROLLA, M. E.; ROSA, S. G. Caracterização Limnológica da Represa de Pontal, Itabira (MG). Acta Limnológica Brasiliensis, v. 3, p. 173-199, 1990.

DALEY, R. J.; HOBBIE, J. E. Direct counts of aquatic bacteria by a modified epifluorescence technique. Limnology and Oceanography, v. 20, p. 875-882, 1975.

DE FILLIPO, R.; GOMES, E. L.; LENZ-CÉSAR, J.; SOARES, C. B. P.; MENEZES, C. F. S. As Alterações na Qualidade da Água Durante o Enchimento do Reservatório de UHE Serra-da-Mesa - GO. In: HENRY, R. Ecologia de Reservatórios: Estrutura, Função e Aspecto Sociais. Botucatu: Fundibio, 2007. p. 321-346.

De WEVER, A.; MUYLAERT, K.; Van Der GUCHT, K.; PIRLOT, S.; COCQUYT, C.; DESCY, J. P.; PLISNIER, P. D. Bacterial Community Composition in Lake Tanganyika: Vertical and Horizontal Heterogeneity. Applied and Environmental Microbiology, v. 71, n. 9, p. 5029-5037, 2005.

DIAS, N. N.; NICOLAU, A.; CARVALHO, G. S.; MOTA, M.; LIMA, N. Os protozoários como ferramenta da monitorização biotecnológica da poluição: Ensaios In Vitro. In: CONFERÊNCIA NACIONAL SOBRE A QUALIDADE DO AMBIENTE, 6., 1999, Lisboa. Actas... Lisboa: Universidade Nova, 1999. v. 2, p. 789-798.

DOLAN, J. R.; PÉREZ, M. T. Costs, benefits and characteristics of mixotrophy in marine oligotrichs. Freshwater Biology, v. 45, p. 227-238, 2000.

DOLAN, J. R.; CLAUSTRE, H.; CARLOTTI, F.; PLOUNEVEZ, S.; MOUTIN, T. Microzooplankton diversity: relationships of tintinnid ciliates with resouces, competiors and predators from the Atantic Coast of Morocco to the Eastern Mediterranean. Deep-Sea Research, v. 49, p. 1217-1232, 2002.

EATON, A.D.; CLESCERI, L.S.; GREENBERG, A. E. Standard Methods for the Examination of Water and Wastewater. 19. ed. Baltimore: Editora United Book Press, 1995. p. 4-98.

EDMONDSON, W. T. Freshwater Biology. 2. ed. New York: Editora: Wiley, 1959. p. 1248. 
ELLOUMI, J.; CARRIAS, J. F.; AYADI, H.; SIME-NGANDO, T.; BOUKHRIS, M.; BOUAIIN, A. Composition and distribution of planktonic ciliates from ponds of different salinity in the solar saltwork of Sfax, Tunisia. Estuarine Coastal and Shelf Science, v. 67, p. 21-29, 2006.

ESPÍNDOLA, E. L. G.; MAUAD, F. F.; SCHALCH, V.; ROCHA, O.; FELICIDADE, N.; RIETZLER, A. C. Recursos Hidroenergéticos: usos, impactos e planejamento integrado. São Carlos: Rima, 2002. p. 292.

ESTEVES, F. A Fundamentos de Limnologia. 2. ed. Rio de Janeiro: Editora Interciência, 1998. p. 602.

FENCHEL, T. Marine plankton food chain. Annual Review of Ecology Systems, v. 19, p. $19-38,1988$.

FENCHEL, T. The role of protozoa in nature in terms of functional properties related to size. Zoology and Science, v. 7, p. 51-58, 1990.

FOISSNER, W. J.; BERGER, H. A user friendly guide to the ciliates (Protozoa, Ciliophora) commonly used by hydrobiologists as bioindicators in rivers, lakes, and waste waters, with notes on their ecology. Freshwater Biology, v. 35, p. 375-482, 1996.

FOISSNER, W. J.; BERGER, H.; KOHMANN, F. Taxonomishe und ökologische Revision der Ciliaten des Saprobiensystems - Band II: Peritrichia, Heterotrichida, Odontostomatida - Informationsberichte des Bayer. Landesamtes für Wasserwirtschaft, v. 5, p. 1-502, 1992.

FOISSNER, W.; BERGER, H., SCHAUMBURG, J. Identification and Ecology of Limnetic Plankton Ciliates. Bavarian: Editora Munichen, 1999. p. 793.

FRACÁCIO, R. Utilização de bioensaios ecotoxicológicos com Danio rerio (Cypriniformes, Cyprinidae) e análises limnológicas para a avaliação ambiental dos reservatórios do Médio e Baixo Tietê (SP). 223 f. Dissertação (Mestrado) - Escola de Engenharia de São Carlos, Universidade de São Paulo, São Carlos, 2001.

FUKUMA, H. T.; DE NADAI FERNANDES, E. A.; NASCIMENTO, M. P.; QUINELATO, A. L. Separation and spectrophotometric determination of thorium contained in uranium concentrates. Journal of Radioanalytical and Nuclear Chemistry, 2001.

GARCIA, O. Jr. Estudos da Biolixiviação de Minérios de UrÂnio por Thiobacillus ferrooxidans. 261 f. Tese (Doutorado) - Instituto de Biologia da Universidade Estadual de Campinas, Campinas, São Paulo, 1989.

GARCÍA-SANTANA, C.; GONZÁLEZ-MARTÍNEZ, S. Ciliated protozoa and organic load at low temperatures in na aerated biofilter. Water Science and Technology, v. 46, n. 1-2, p. 243-267, 2002. 
GILBERT, J. J. Jumping behavior in the Oligotrich Ciliates Strobilidium velox and Halteria grandinella, and Its significance as a Defense against Rotifer Predators. Microbial Ecology, v. 27, p. 189-200, 1994.

GOMES, E. A. T.; GODINHO, M. J. L. Structure of the protozooplankton community in a tropical shallow and eutrophic lake in Brazil. Acta Oecologica International Journal of Ecology, v. 24, p. 153-161, 2003.

GONZÁLEZ, J. M.; IRIBERRI, J.; EGEA, L.; BARCINA, I. Differencial Rates of Digestion of Bactéria by Freshwater and Marine Phagotrophic Protozoa. Applied and Environmental Microbiology, v. 56, n. 6, p. 1851-1857, 1990.

GONZÁLEZ, J. M. Bacterivory Rate Estimates and Fraction of Active Bacterivores in Natural Protist Assemblages from Aquatic Systems. Applied and Environmental Microbiology, v. 65, n. 4, p. 1463-1474, 1999.

GRAHAM, J. M.; KENT, A. D.; LAUSTER, G. H.; YANNARELL, A. C.; GRAHAM, L. E.; TRIPLETT, E. W. Seasonal Dynamics of Phytoplankton and Planktonic Protozoan Communities in a Northern Temperate Humic Lake: Diversity in a Dinoflagellate Dominated System. Microbial Ecology, v. 48, p. 528-540, 2004.

GRANDLIC, C. J.; GEIB, I.; PILON, R.; SANDRIN, T. R. Lead pollution in a large, prairie-pothole lake (Rush Lake, WI, USA): Effects on abundance and community structure of indigenous sediment bacteria. Environmental Pollution, v. 144, p. 119-126, 2006.

HAHN, M. W.; MOORE, E. R. B.; HÖFLE, M. G. Bacterial Filament Formation, a Defense Mechanism against Flagellate Grazing, Is Growth Rate Controlled in Bactéria of Different Phyla. Applied and Environmental Microbiology, v. 65, n. 1, p. 25-35, 1999.

HARDOIM, E. L.; HECKMAN, C. W. The seasonal succession of biotic communities in Wetlands of the Tropical wet and dry climatic zone: IV. The-free living sarcodines and ciliates of the Pantanal of Mato Grosso, Brazil. Internationale Revue der gesamten Hydrobiologie, v. 83, p. 367-384, 1996.

HENRY, R. Ecologia de Reservatórios: Estrutura, Função e Aspectos Sociais. Botucatu: Editora Funbio, 2007. Cap. 1, p. 800.

HOBBIE, J. E.; DALEY, R. J.; JASPER, S. Use of Nuclepore Filters for Counting Bacteria by Fluorescence Microscopy. Applied and Environmental Microbiology, v. 33, n. 5, p. 1225-1228, 1977.

INDÚSTRIAS NUCLEARES DO BRASIL. Ciclo do Combustível Nuclear. Disponíve em: <http://www.inb.gov.br/caldas.asp>. Acesso em: 20 ago. 2007.

INSTITUTO BRASILEIRO DE MINERAÇÃO. Produção Mineral Brasileira. Disponível em: <http://www.ibram.org.br/>. Acesso em: 01 jun. 2008.

INSTITUTO DE GESTÃO DAS ÁGUAS DE MINAS. Gestão de Recursos Hídrico - Comitês de Bacias. Disponível em: < http://www.igam.mg.gov.br/>. Acesso em: 10 jun. 2008. 
JEFFREY, S. W.; HUMPHREY, G. F. New spectrophotometric equations for the determining of chlorophylls a, b, c1 and c2 of higher plants, algae and natural phytoplankton. Biochemical and Physiological Pflanzen, v. 167, p. 191-194, 1975.

JIANG, J. G.; SHEN, Y. F. Use of the aquatic protozoa to formulate a community biotic index for an urban water system. Science of the Total Environment, v. 346, p. 99-111, 2005.

JUGNIA, L. B.; TADONLÉKÉ, R. D.; SIME-NGANDO, T.; FOTO, S. M.; KEMKA, $\mathrm{N}$. Short-term variations in the abundance and cell volume of bacterioplankton in na artificial tropical lake. Hydrobiologia, v. 385, p. 113-119, 1998.

JÜRGENS, K. Impact of Daphnia on planktonic microbial food webs: a review. Microbial Food Webs, v. 8, p. 295-324, 1994.

JÜRGENS, K.; PERNTHALER, J.; SCHALLA, S.; AMANN, R. Morphological and Compositional Changes in a Planktonic Bacterial Community in Response to Enhanced Protozoan Grazing. Applied and Environmental Microbiology, v. 65, n. 3, p. 1241-1255, 1999.

JYOTHIBABU, R.; MADHU, N. V.; MAHESWARAN, P. A., JAYALAKSHMY, K. V.; NAIR, K. K. C.; ACHUTHANKUTTY, C. T. Seasonal variation of microzooplankton $(20-200 \mu \mathrm{m})$ and its possible implications on the vertical carbon flux in the western Bay of Bengal. Continental Shelf Research, v. 28, p. 737-755, 2008.

KENT STATE UNIVERSITY. The Great North American Secchi dip-in. Relating Trophic State Indices to the State of the Waterbody. Disponível em: <http://dipin.kent.edu>. Acesso em: 06 de abr. 2008.

KISAND, V.; NÕGES, T. Abiotic and biotic factors regulating dynamics of bacterioplankton in a large shallow lake. Microbiology and Ecology, v. 50, p. 5162, 2004.

KUCHLER, I. L. Interação entre Tório e Compostos Húmicos em águas do Morro do Ferro (Poços de Caldas, MG). 152 f. Dissertação (Mestrado) Departamento de Química, Pontifícea Universidade Católica do Rio de Janeiro, Rio de Janeiro, 1986.

LAGE-FILHO, A. L. Características ecológicas e limnológicas da bacia hidrográfica do Ribeirão das Antas, no período de menores precipitações (Poços de Caldas - MG). 192 f. Dissertação (Mestrado) - Escola de Engenharia de São Carlos, Universidade de São Paulo, São Paulo, 1996.

LAPPONI, J. C. Estatística: usando Excel: versões 4 e 5. São Paulo: Lapponi Treinamento e Editora, 1995. p. 95-112.

LAYBOURN-PARRY, J. Protozoan Planckton Ecology. London: Chapman \& Hall, 1992. p. 231. 
Le JEUNE, A. H.; CHARPIN, M.; SARGOS, D.; LENAIN, J. F.; DELUCHAT, V.; NGAYILA, N.; BAUDU, M.; AMBLARD, C. Planktonic microbial community responses to added copper. Aquatic Toxicology, v. 83, p. 223-237, 2007.

LEE, J. J.; HUTNER, S. H.; BOVEE, E. C. An illustrated guide to the Protozoa. Kansas: Society of Protozoologists, 1985. p. 629.

LEE, J. J.; SOLDO, A. T. Prototols in Protozoology. In: FOISSNER, W. Evaluating water quality using protozoa and saprobity indexes. 1. ed. v. 2. Cap. 1 Salzburg: Editora Society of Protozoology, 1992. p. $1-19$.

LEE, S.; BASU, S.; TYLER, C. W.; WEI, I. W. Ciliate populations as bio-indicators at Deer Island Treatment Plant. Advances in Environmental Research, v. 8, p. 371-378, 2004.

LIDE, R. D. CRC HANDBOOCK of CHEMISTRY and PHYSICS. 84. ed. Editora: CRC Press LLC, 2003 - 2004.

LORENZEN, C.J. Determination of chlorophyll and phaeopigments: spectrophotometric equations. Limnology and Oceanography, v. 12, p. 343-346, 1967.

LUGO, A.; MARTINEZ, S.; RIVERA, F.; SANCHEZ, R. Protozoan indicator communities in waste stabilization pond systems. Biological Approach to Sewage Treatment Process: Current Status and Perspectives, p. 115-118, 1991.

LYEW, D.; SHEPPARD, J. Technical Note Use of Conductivity to Monitor the Treatment of Acid Mine Drainage by Sulphate-Reducing Bacteria. Water Research, v. 35, n 8, p. 2081-2086, 2001.

MADONI, P.; STEBAN, G.; GORBI, G. Acute toxicity of Cadmium, Copper, Mercury, and Zinc to ciliates from Activated Sludge Plants. Bulletin of Environmental Contamination and Toxicology, v. 49, p. 900-905, 1992.

MADONI, P. Ciliated protozoa and water quality in the Parma River (Northern Italy): long-term changes in the community structure. Hydrobiologia, v. 264, p. 129-135, 1993.

MADONI, P. Ciliated protozoan communities and saprobic evaluation of water quality in the hilly zone of some tributaries of the Po River (northern Italy). Hydrobiologia, v. 541, p. 55-69, 2005.

MADONI, P.; ROMEO, M. G. Acute toxicity of heavy metals towards freshwater ciliated protists. Environmental and Pollution, v. 141, p. 1-7, 2006.

MARGALEF, R. Counting. In: VOLLENWEIDER, R. A. A mannual on methods for measuring primary production in aquatic environments and molecular approaches. New York: Oxford, 1969. p. 9-46.

MARKER, A.F.H.; NUSCH, E.A.; RAI, H.; RIEMANN, B. The measurement of photosynthetic pigments in freshwaters and standardization of methods: 
conclusions and recommendations. Archive Hydrobiological Beih Ergebn Limnologie, v. 14, p. 91-106, 1980.

MARQUES, C. N. Análise morfológica de cianobactérias isoladas de efluentes de uma mina de urânio destativada com ênfase em Aphanothece e sua capacidade de biossorção do ${ }^{226}$ Ra. 118 f. Dissertação (Mestrado) - Centro de Energia Nuclear na Agricultura da Universidade de São Paulo, São Paulo, 2006.

MASSON, M.; BLANC, G.; SCHAFER, J. Geochemical signal and source contribution to heavy metal $(\mathrm{Cd}, \mathrm{Zn}, \mathrm{Pb}, \mathrm{Cu})$ fluxes into the Gironde Estuary via its major tributaries. Science of the Total Environment, v. 370, p. 133-146, 2006.

MATZ, C.; JÜRGENS, K. Effects of Hydrophobic and Electrostatic Cell Surface Properties of Bactéria on Feeding Rates of Heterotrophic Nanoflagellates. Applied and Environmental Microbiology, v. 67, n. 2, p. 814-820, 2001.

MATZ, C.; JÜRGENS, K. High Motility Reduces Grazing Mortality of Planktonic Bacteria. Applied and Environmental Microbiology, v. 71, n. 2, p. 921-929, 2005.

MODENUTT, B.; QUEIMALIÑOS, C.; BALSEIRO, E.; REISSIG, M. Impact of different zooplankton structures on the microbial food web of a South Andean oligotrophic lake. Acta Oecologica - International Journal of Ecology, v. 24, p. 289-298, 2003.

MOURA, A. N.; DANTAS, E. W.; BITTENCOURT-OLIVEIRA, M. C. Structure of the Phytoplankton in a Water Supply System in the State of Pernambuco - Brazil. Brazilian Archives of Biology and Technology, v. 50, n. 4, p. 645-654, 2007.

MUDRYK, Z. J.; DWULIT, M. Interaction of estuarine bacterioneuston and bacterioplankton with elevated mercury concentrations. Polish Journal of Ecology, v. 52, n. 3, p. 301-310, 2004.

NAKANO, A.; BAN, S. Microbial communities in oligotrophic Lake Toya, Japan. Limnology, v. 4, p. 19-27, 2003.

NASCIMENTO, M. R. L. Proposição de valores de Referência para Concentração de Metais e Metalóides em Sedimentos Limnícos e Fluviais na Bacia Hidrográfica do Rio Tietê, SP. Tese (Doutorado) - Centro de Ciências Exatas e de Tecnología, Departamento de Química, Universidade Federal de São Carlos, São Carlos, 2003.

NASCIMENTO, M. R. L.; FUKUMA, H. T.; HORTELLANI, M. A. Projeto Itataia Controle de processo na produção de ácidos fosfórico e urânio. Poços de Caldas: INB, 1988. p. 143. (Manual de Métodos e Análises Químicas).

NOGUEIRA, M. G.; MATSUMURA-TUNDISI, T. Limnologia de um sistema artificial raso (Represa de Monjolinho - São Carlos, SP). I - Dinâmica das variáveis físicas e químicas. Revista Brasileira de Biologia, Rio de Janeiro, v. 54, n. 1, p. 147-159, 1994. 
NORDSTROM, D. K.; SMELLE, J. A. T.; WOLF, M. Chemical and isotopic composition of groundwaters and their seasonal variability at the Osamu Utsumi mine and Morro do Ferro analogue study sites, Poços de Caldas, Brazil. Sweden: Swedish Nuclear Fuel and Waste Management CO, 1990. p. 111.

ODUM, E. P. Ecología. Rio de Janeiro: Guanabara Koogan, 1988. p. 434.

PACE, M. L.; ORCUTT Jr. J. D. The relative importance ofprotozoans, rotifers, and crustaceans in a freshwater zooplankton community. Limnologycal and Oceanography, v. 26, p. 822-830, 1981.

PACKROFF, G. Protozooplankton in acidic mining lakes with special respect to ciliates. Hydrobiologia, v. 433, p. 157-166, 2000.

PAIVA, T. S.; SILVA-NETO, I. D. Ciliate Protists from Cabiúnas Lagoon (Restinga de Jurubatiba, Macaé, Rio de Janeiro) with emphasis on water quality indicator species and Description of Oxytricha marcili sp. n. Brazilian Journal of Biology, v. 64 , p. $465-478,2004$.

PANTLE, R.; BUCK, H. Die biologische Überwachung der Gewässer und die Darstellung der Ergebnisse. Gas - u. WassFach (WasserlAbwasser) v. 96, p. $604-620.1955$.

PEDRÓS-ALIÓ, C.; GUERRERO, R. Prokaryotology for the limnologist. In: MARGALEF, R. Limnology Now: a Paradigm of Planetary Problems. Elsevier, Oxford: 1994. 37-57 p.

PENNAK, R. W. Freshwater Invertebrates. New York: Editora: Ronald, 1953. p.769.

PIVETTA, F. R. Estudo da Composição Química de Águas do Morro do Ferro (MG): Transporte de Tório e de Diversos Elementos Traço em solução. $161 \mathrm{f}$. Dissertação (Mestrado) - Departamento de Químicas, Pontifícia Universidade Católica do Rio de Janeiro, Rio de Janeiro, 1983.

POMPÊO, M. L. M.; MOSCHINI-CARLOS, V.; ALEXANDRE, N. Z.; SANTO, E. Qualidade da água em região alterada pela mineração de carvão na microbacia do rio Fiorita (Siderópolis, Estado de Santa Catarina, Brasil). Acta Scientiarum. Biological Sciences. V. 26, n. 2, p. 125-136, 2004.

PORTER, K. G.; PAERL, H.; HODSON, R.; PACE, M. L.; PRISCU, J.; RIEMMAN, B.; SCAVIA, D.; STOCKNER, J. G. Microbial interactions in lake food web. In: CARPENTER, S. R. (Ed). Complex interactions in Lake Communities. SpringerVerlag, New Yori, p. 209-227, 1988.

PRADO, V. C. S. O Impacto da Produção de Concentrado de Urânio sobre a Qualidade da Água dos rios: Um Estudo de caso na Área do Complexo Minero - Industrial do Planalto de Poços de Caldas. 195 f. Dissertação (Mestrado) - Universidade Federal do Rio de Janeiro, Rio de Janeiro, 1994. 
PUTT, M.; STOECKER, D. K. An experimentally determined carbon: volume ratio for marine "oligotrichous" ciliates from estuarine and coastal waters. Limnology and Oceanography, v. 34, n. 6, p. 1097-1103, 1989.

RAKOCEVIC-NEDOVIC, J.; HOLLERT, H. Phytoplankton and Chlorophyll a as Trophic State Indices of Lake Skadas (Montenegro, Balkan). Environmental Science \& Pollution Research, v. 12, n. 3, p. 146-152, 2005.

REBOUÇAS, A. C.; BRAGA, B.; TUNDISI, J. G. Águas Doces do Brasil: Capital Ecológico, Uso e Conservação. 3. ed. São Paulo: Editora Escrituras, 2006. p. 748.

REGALI-SELEGHIM, M. H. Flutuações nas comunidades planctônicas e bentônicas de um ecossistema artificial raso (Represa do Monjolinho - São Carlos - SP), com ênfase nas populações de protozoários e bactérias. $162 \mathrm{f}$. Dissertação (Mestrado) - Faculdade de Biologia, Universidade Federal de São Carlos, São Carlos, São Paulo, 1992.

REGALI-SELEGHIM, M. H. Rede Trófica Microbiana em um Sistema Eutrófico Raso (Reservatório do Monjolinho-São Carlos-SP)-Estrutura e Função. 92 f. Tese (Doutorado) - Ciências - Programa de Pós-Graduação em Ecologia e Recursos Naturais, Universidade Federla de São Carlos, São Carlos, São Paulo, 2001.

REGALI-SELEGHIM, M. H.; GODINHO, M. J. L. Peritrich epibiont protozoans in the zooplankton of a subtropical shallow aquatic system (Monjolinho Reservoir, São Carlos, Brazil). Journal of Plankton Research, v. 26, p. 501-508, 2004.

REGALI-SELEGHIM, M. H. Taxonomia de Protozoários. In: Taxonomia: Microbiana, de Procariontes, de Fundo, de Protozoários e de Vírus. Centro de Gestão e Estudos Estratégicos. p. 50, 2005. Disponível em: < http://www.biota.org.br/publi/banco/index?show+49489473>. Acesso em: 10 mai. 2008.

RELATÓRIO AMBIENTAL. Relatório Indústrias Nucleares do Brasil (INB) Complexo Industrial do Planalto de Poços de Caldas - CIPC para solicitar Licença de Operação junto ao IBAMA. Poços de Caldas: Diretoria de Recursos Minerais DRM da INB, 1999. 110 p.

RIETZLER, A. C.; FONSECA, A. L.; LOPES, G. P. Heavy metals in tributaries of Pampulha Reservoir, Minas Gerais. Brazilian Journal of Biology, v. 63, n. 3, p. 363-370, 2001.

RODGHER, S.; ESPÍNDOLA, E. L. G.; ROCHA, O.; FRACÁCIO, R.; PEREIRA, R. H. G.; RODRIGUES, M. H. S. Limnological and Ecotoxicological Studies in the Cascade of Reservoirs in the TietÊ River (São Paulo, Brazil). Brazilian Journal of Biology, v. 65, n. 4, p. 697-710, 2005.

RONQUI, L. B. Caracterização sazonal de bactérias, protozoários e de fitoflagelados planctônicos na Represa das Antas em Poços de Caldas Minas Gerais. 70 f. (Monografia) - Centro Universitário Fundação de Ensino Octávio Bastos, São João da Boa Vista, 2004. 
RUDD, T. Heavy Metals in wastewater and sludge treatment process. Sources, analyses and legislation. London: CRC Press, 1987. v. 1, p. 2.

SALUSSO, M. M.; MORAÑA, L. B. Comparación de índices bióticos utilizados en el monitoreo de dos sistemas lóticos del noroeste argentino. Revista de Biologia Tropical, v. 50, n. 1, p. 327-336, 2002.

SAMUELSSON, K.; BERGLUND, J.; ANDERSSON, A. Factors structuring the heterotrophic flagellate and ciliate community along a brackish water primary production gradient. Journal of Plankton Research, v. 28, n. 4, p. 345-359, 2006.

SHERR, E. B.; SHERR, B. F. Role of microbes in pelagic foos webs: A revised concept. Limnology and Oceanography, v. 33, n. 5, p. 1225-1227, 1988.

SHERR, E. B.; SHERR, F. F.; MCDANIEL, J. Effect of Protistan Grazing on the Frequency of Dividing Cells in Bacterioplankton Assemblages. Applied and Environmental Microbiology, v. 58, p. 2381-2385, 1992.

SHERR, E. B.; SHERR, B. F. Preservation and storage of samples for enumeration of heterotrophics protists. In: KEMP, P. F.; SHERR, E. B; SHERR; B. F.; COLE, J. J. Handbook of methods in aquatic micobial ecology. Flórida: Lewis Publishers, 1993.

SHERR, B. F.; SHERR, E. B. Marine microbes: an overview. In: KIRCKMAN, D. Microbial ecology of the oceans. 1. ed. New York: Editora Wiley-Liss, 2000. p. 13-46.

SHERR, E. B.; SHERR, B. F. Significance of predation by protests in aquatic microbial food webs. Journal Antonie Van Leeuwenhoek, v. 81, p. 293-308, 2002.

SIMÉK, K.; BOBKOVA, J.; MACEK, M.; NEDOMA, J. Ciliate grazing on picoplankton in a eutrophic reservoir during the summer phytoplankton maximum: a study at the species and community level. Limnology and Oceanography, v. 40, p. 1077-1090, 1995.

SIMÉK, K.; PERNTHALLER, J.; WEINBAUER, M. G.; HORNÁK, K.; DOLAN, J. R.; NEDOMA, J.; MASÍN, M.; AMANN, R. Changes in Bacterial Community Composition and Dynamics and Viral Mortality Rates Associated with Enhanced Flagellate Grazing in a Mesoeutrophic Reservoir. Applied and Environmental Microbiology, v. 67, n. 6, p. 2723-2733, 2001.

SONNTAG, B.; POSCH, T.; KLAMMER, S.; TEUBNER, K.; PSENNER, R. Phagotrophic ciliates and flagellates in na oligotrophic, deep, alpine lake: contrasting variability with seasons and depths. Aquatic and Microbiol Ecology, v. 43 , p. 193-207, 2006.

SOROKIN, Y. I.; KADOTA, H. Techniques for the assessment of microbial production and decomposition in fresh waters. Oxford: Editora Blackwell, 1972. p. 112. 
SOUZA, P.V. Drenagens ácidas do estéril piritoso da mina de urânio de Poços de Caldas: interpretação e implicações ambientais. 141 f. Dissertação (Mestrado) - Universidade de São Paulo, São Paulo, 1995.

SPERLING, M. VON. Introdução à qualidade das águas e ao tratamento de esgotos. Belo Horizonte: Editora: FCO. 1995. p. 239.

STOECKER, D. K. Mixotrophy among Dinoflagellates. Journal of Eukariotic Microbiology, v. 46, n. 4, p. 397-401, 1999.

STRAIN, H. H.; MANNING, W. M.; HARDIN, G. Chlorophyll c (chlorofucine) of diatoms and dinoflagellates. The Journal of Biological Chemistry, p. 655-668, 1943.

SUZUKI, Y.; BANFIELD, J. Geomicrobiology of uranium. In: BURNS, P.; FINCH, R. Uranium: Mineralogy, Geochemistry and the Environmet. Virginia: Virginia Pol. Inst, 1999. v. 38, p. 415.

TAKAMURA, N.; SHEN, Y.; XIE, P. Species richness of Protozoa in Japanese lakes. Limnology, v. 1, p. 91-106, 2000.

TANAKA, T.; LOVDAL, T.; GROSSART, H. P.; LARSEN, A.; SCHULZ, K. G.; RIEBESELL, V. Availability of phosphate for phytoplankton and bacteria and of labile organic carbon for bacteria at different $\mathrm{pCO}_{2}$ levels in a mesocosm study. Biogeosciences Discuss, v. 4, p. 3937-3960, 2007.

TEIXEIRA, C; TUNDISI, J. G.; KUTNER, M. B. Plankton studies in a mangrove II. The standing stock and some ecological factors. Bolmish Institute Oceanography, v. 24, p. 23-41, 1965.

THORNTON, K. W. Perspectives on reservoir limnology. In: THORNTON, W. K.; KIMMEL, B. L.; PAYNE, F. E. Reservoir Limnology: Ecological Perspectives. New York: John Wiley e Sons, 1990. p. 248.

TIROK, K.; GAEDKE, U. Regulation of planktonic ciliate dynamics and functional composition during spring in Lake Constance. Aquatic and Microbial Ecology, v. 49, p. 87-100, 2007.

TITTEL, J.; BISSINGER, V.; ZIPPEL, B.; GAEDKE, U.; BELL, E.; LORKE, A.; KAMJUNKE, N. Mixotrophs combine resource use to outcompete specialists: Implications for aquatic food webs. Proceedings of the National Academy of Sciences of the United States of America, v. 100, n. 22, p. 12776-12781, 2003.

TOLEDO Jr. A. P.; TALARICO, N.; CHINEZ, S.J.; AGUDO, E.G. Aplicação de modelos simplificados para a avaliação de processo de eutrofização em lagos e reservatórios tropicais. In: CONGRESSO BRASILEIRO DE ENGENHARIA SANITÁRIA E AMBIENTAL, 12., Camboriu, 1983. Anais... Camboriu: CETESB, 1983. p. 1-34.

TREMAINE, S. C.; MILLS, A. L. Impacto of Water Column Acidification on Protozoan Bacterivory at the Lake Sediment-Water Interface. Applied and Environmental Microbiology, v. 57, n. 3, p. 775-784, 1991. 
TUNDISI, J. G. Planejamento e Gerenciamento de Lagos e Reservatórios: uma abordagem integrada ao problema da eutrofização. São Carlos: Rima, 2001. $385 \mathrm{p}$.

TUNDISI, J. G.; MATSUMURA-TUNDISI, T.; ARANTES, J. J. D.; TUNDISI, J. E. M.; MANZINI, N. F.; DUCROT, R. The Response of Carlos Botelho (Lobo, Broa) Reservoir to the passage of cold fronts as reflected by physical, chemical, and biological variables. Brazilian Journal of Biology, v. 64, n. 1, p. 177-186, 2004.

TUNDISI, J. G.; MATSUMURA-TUNDISI, T.; ROCHA, O. Ecossistemas de águas interiores. In: REBOUÇAS, A. C.; BRAGA, B.; TUNDISI, J. G. Águas Doces no Brasil: Capital Ecológico, Uso e Conservação. 3. ed. São Paulo: Escrituras, 2006. p. 748.

TUNDISI, J. G. Reservatórios como Sistemas Complexos: Teoria, Aplicações e Perspectivas para Usos Múltiplos. In: HENRY, R. Ecologia de Reservatórios: Estrutura, Função e Aspectos Sociais. Botucatu: Fundibio, 2007. p. 19-38.

VALE, M. G. R. Introdução e Otimização de Métodos para Análise de Tório e UrÂnio via Espectroscopia $\alpha$ e suas Aplicações na Análise de Águas do Morro do Ferro (MG). 101 f. Dissertação (Mestrado) - Departamento de Química, Pontifícia Universidade Católica do Rio de Janeiro, Rio de Janeiro, 1982.

VELHO, L. F. M.; PEREIRA, D. G.; PAGIORO, T. A.; SANTOS, V. D.; PERENHA, M. C. Z.; LANSAC-TÖHA, F. A. Abundance, biomass and size structure of planktonic ciliates in reservoirs with distinct trophic states. Acta Limnologica Brasiliensis, v. 4, n. 17, p. 361-371, 2005.

VERCELLINO, I. S.; BICUDO, D. C. Sucessão da comunidade de algas perifitícas em reservatório oligotrófico tropical (São Paulo, Brasil): comparação entre período seco e chuvoso. Revista Brasileira de Botânica, v. 29, n. 3, p. 363-377, 2006.

WEISSE, T. Growth and production of heterotrophic nanoflagellates in a mesoeutrophic lake. Journal Plankton Research, v. 19, p. 703-722, 1997.

WEISSE, T.; STADLER, P. Effect of $\mathrm{pH}$ on growth, cell volume, and production of freshwater ciliates, and implications for their distribution. Limnology and Oceanography, v. 51, n. 4, p. 1708-1715, 2006.

WOLLMANN, K.; DENEKE, R.; NIXDORF, B.; PACKROFF, G. Dynamics of planktonic food webs in three mining lakes across a pH gradient ( $\mathrm{pH} 2-4)$. Hydrobiologia, v. 433, p. 3-14, 2000.

WORLD HEALTH ORGANIZATION. The chemical toxicity of uranium. Disponivel em: $\quad$ http://www.who.int/ionizing_radiation/pub_meet/en/Depluranium4.pdf $>$. Acesso em: 20 jun. 2008.

XU, M.; CAO, H.; XIE, P.; DENG, D.; FENG, W.; XU, J. The temporal and spatial distribution, composition and abundance of Protozoa in Chaohu Lake, China: Relationship with eutrophication. European Journal of Protistology, v. 41, p. 183-192, 2005. 
ZINABU, G. M.; TAYLOR, W. D. Bacteria-chlorophyll relationships in Ethiopian lakes of varying salinity: are soda lakes different? Journal of Plankton Research, v. 19, n. 5, p. 647-654, 1997.

ZINGEL, P.; OTT, I. Vertical distribution of planktonic ciliates in strongly stratified temperate lakes. Hydrobiologia, v. 435, p. 19-26, 2000.

YANNARELL, A. C.; TRIPLETT, E. W. Geographic and Environmental Sources of Variation in Lake Bacterial Community Compositon. Applied and Environmental Microbiology, v. 71, n. 1, p. 227-239, 2005. 


\section{GLOSSÁRIO ILUSTRADO DE PROTOZOOLOGIA DA REPRESA DAS ANTAS}

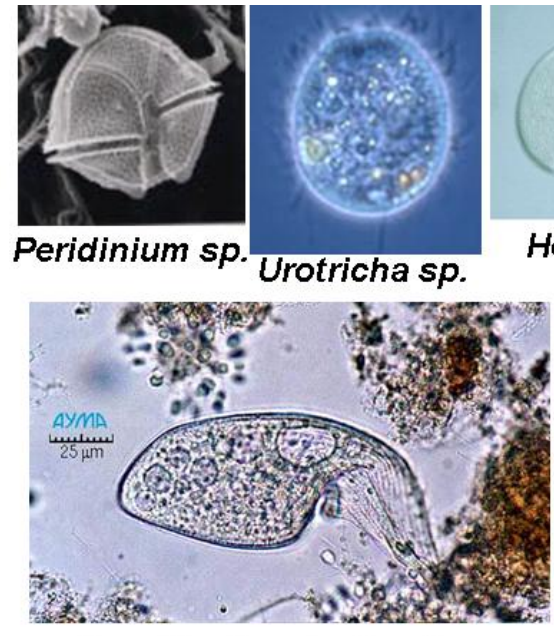

Paradileptus elephantinus

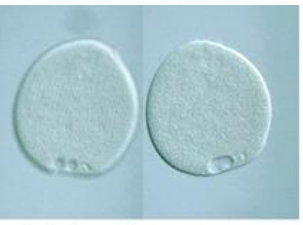

Holophrya sp.

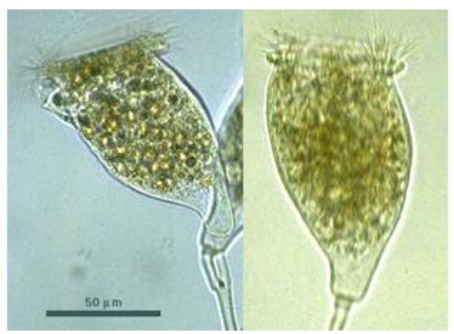

Campanella umbellaria

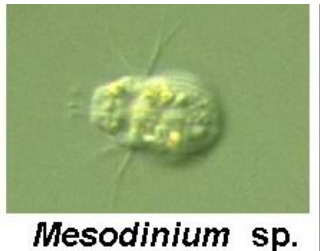

Mesodinium sp.

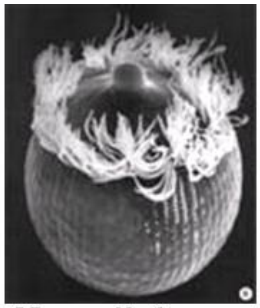

Monodinium sp.

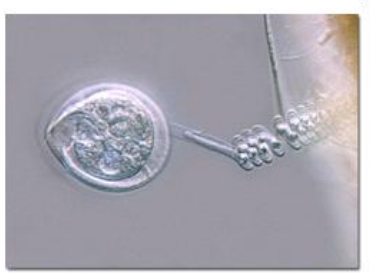

Vorticella sp.

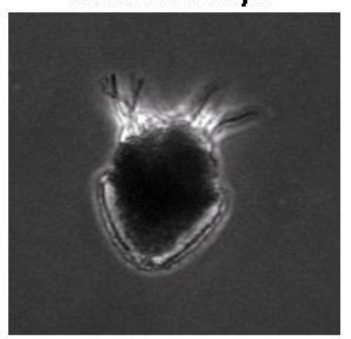

Strombidium sp.

Askenásia sp.

Fonte: google.com.br/images?hl=pt-BR\&q=Ciliophora 


\section{APÊNDICE}

\section{INSTITUIÇÕES ENVOLVIDAS NA PESQUISA}

As Instituições envolvidas no desenvolvimento deste estudo foram os Laboratórios de Radioecologia e de Análises Químicas da Coordenação do Laboratório de Poços de Caldas da Comissão Nacional de Energia Nuclear (LAPOC/CNEN), Poços de Caldas - MG e o Laboratório de Ecologia de Microorganismos Aquáticos (Departamento de Ecologia e Biologia Evolutiva) da Universidade Federal de São Carlos (UFSCar), São Carlos - SP. 
ANEXOS 
ANEXO A

Unidade de tratamento de Minério - Índústrias Nucleares do Brasil e Represa das Antas

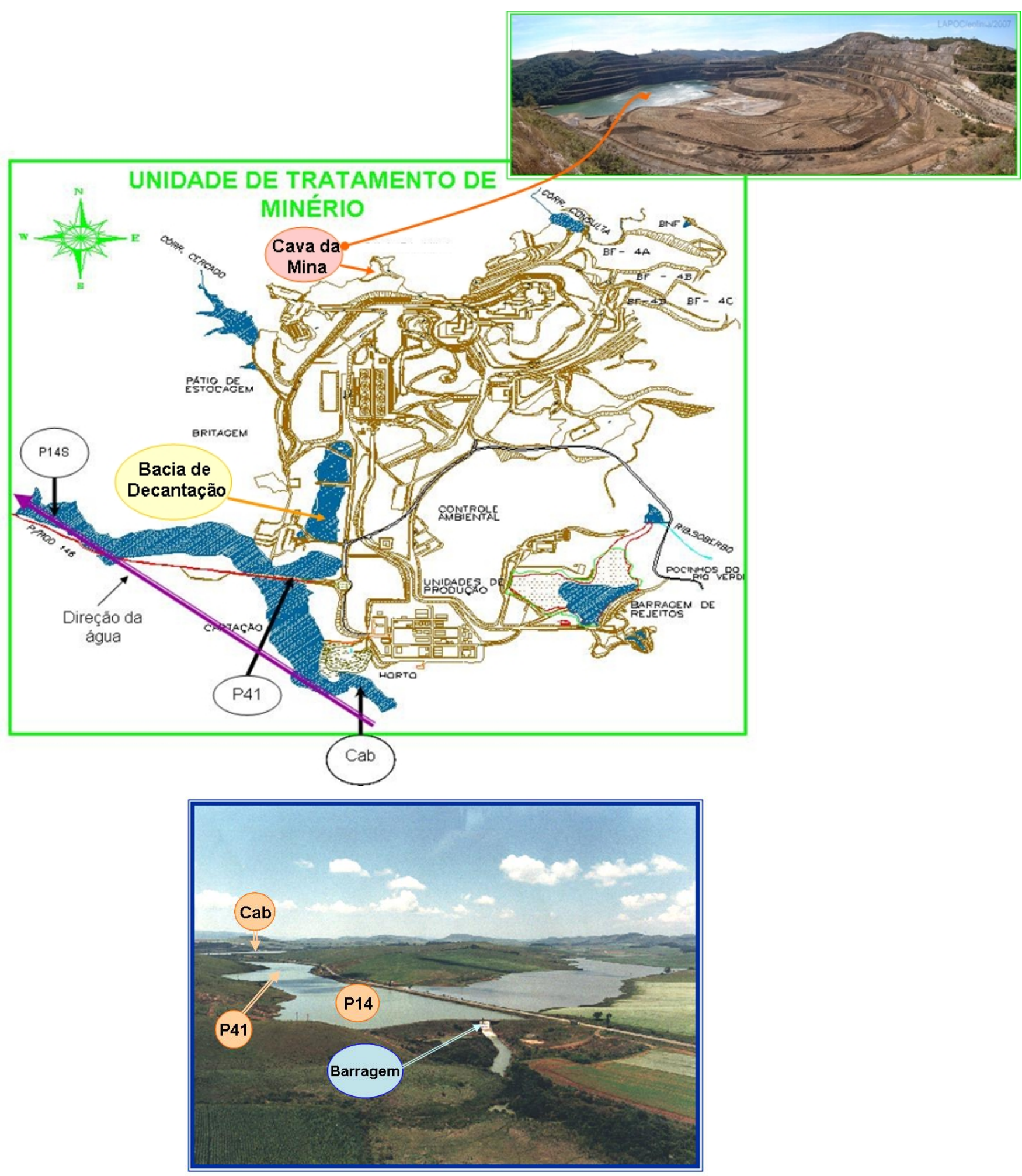




\section{ANEXO B}

\section{Unidade de Tratamento de Minérios - Indústrias Nucleares do Brasil}

A Mina de Urânio Osamu Utsumi (Cava da Mina) consiste na primeira mina de urânio do Brasil, localizada na Unidade de Tratamento de Minérios - Indústrias Nucleares do Brasil ocupa uma área em torno de $15 \mathrm{~km}^{2}$. Tal mina faz parte dos corpos minerados da jazida de urânio da cidade de Poços de Caldas, situada no município de Caldas, região Sul do Estado de Minas Gerais. Esta jazida foi explorada comercialmente pela extinta Indústrias Nucleares do Brasil S/A .

Sendo a Cava da Mina (Mina Osamu Utsumi) o primeiro complexo míneroindustrial do gênero no País, esta atendeu basicamente às demandas de recargas do reator de Angra I e de programas de desenvolvimento tecnológico, onde foram extraídos minerais como urânio, tório entre outros, sendo que deste processo de extração; como resultado; houve a geração de efluente ácido, aliado a ação do ar, água e agentes biológicos gerou a drenagem ácida de mina. Este efluente ácido gerado é tratado quimicamente com hidróxido de cálcio e liberado em uma bacia de decantação próxima ao ponto P41 da Represa das Antas; o tratamento com cal visa a precipitação dos metais, bem como dos radionuclideos presentes, que posteriormente, são liberados por gravidade na Represa das Antas.

O minério encontrado em Caldas, por sua complexa constituição mineralógica, de características únicas, obrigou ao desenvolvimento de um processo original na extração do urânio e elementos associados, o que foi feito pela INB. A mineração realizada a céu aberto permitiu o melhor aproveitamento do minério de urânio, porém, gerou a drenagem ácida de mina.

A unidade da INB situada em Caldas marca o início do desenvolvimento da tecnologia do ciclo do combustível nuclear para geração de energia elétrica no Brasil, desde o processamento químico do urânio até a sua transformação em "yellowcake" (bolo amarelo).

Devido ao esgotamento do urânio economicamente viável nesta unidade de mineração na cidade de Caldas, a prioridade foi à extração e o beneficiamento do mineral na INB situada na cidade de Caetité (BA).

Atualmente a mina Osamu Utsumi está em fase de descomissionamento e suas instalações e equipamentos estão sendo utilizados para a viabilização de novos projetos (INB: http://www.inb.gov.br/caldas.asp). 


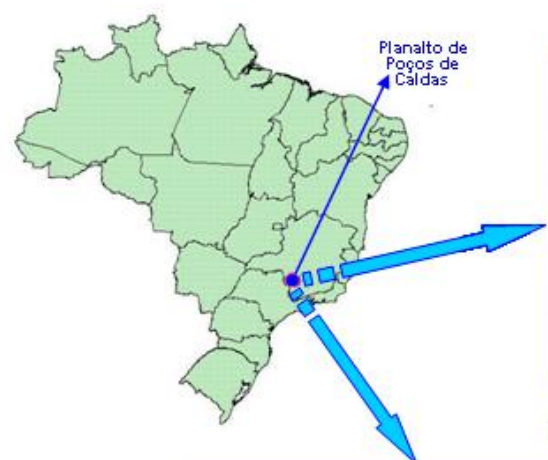

LAPOC-CNEN (Poços de Caldas - M.G.)

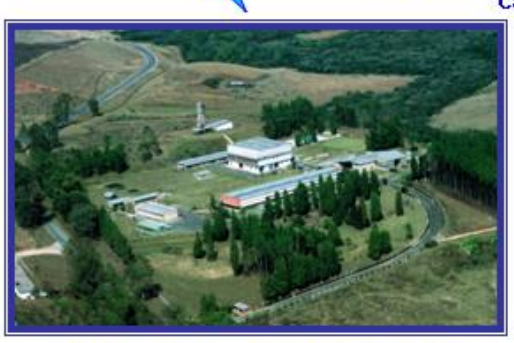

Indústrias Nucleares do Brasil - Unidade de Tratamento de Minérios Caldas (M.G.)

Córrego da Consulta

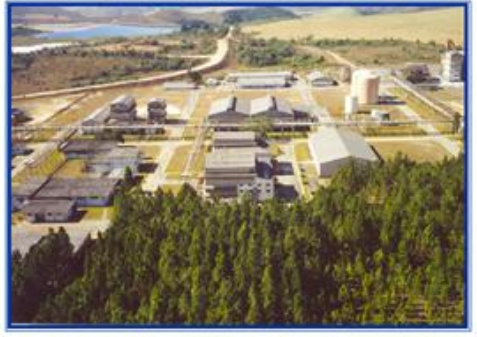

Indústrias Nucleares do Brasil Unidade de Tratamento de Minérios Caldas (M.G.)

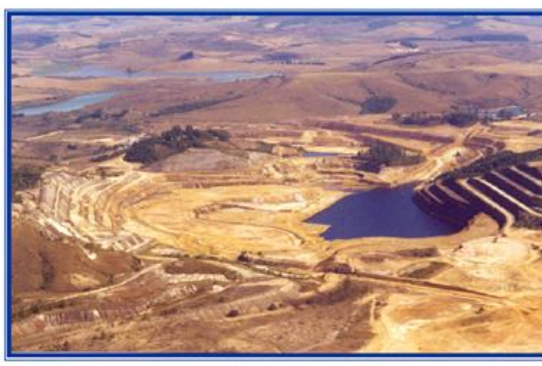

Cava da Mina (CM)
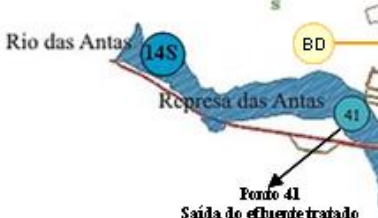

Sáda do fhuenteratiaido

Córrego do Cercado

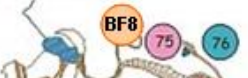
Cava da Mi

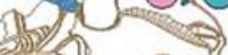

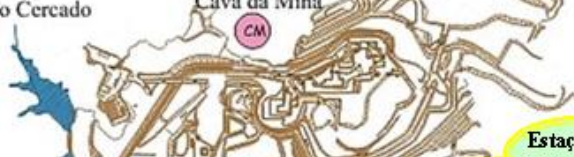
46
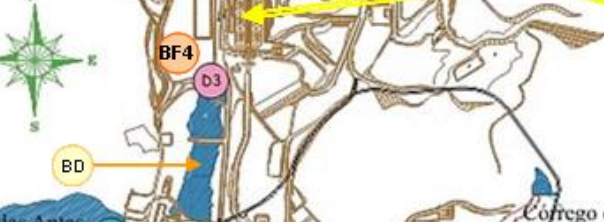

$\Rightarrow$

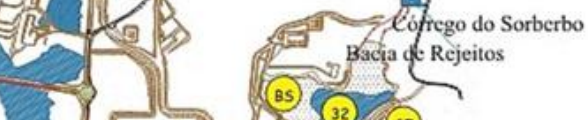
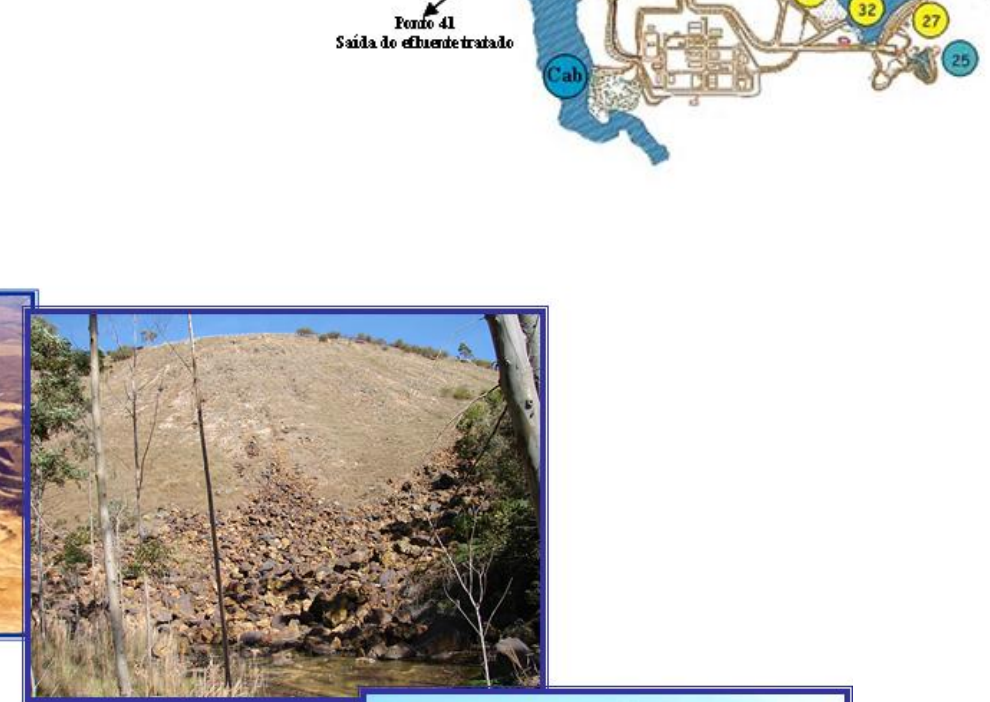

Bota Fora 8 (BF8)
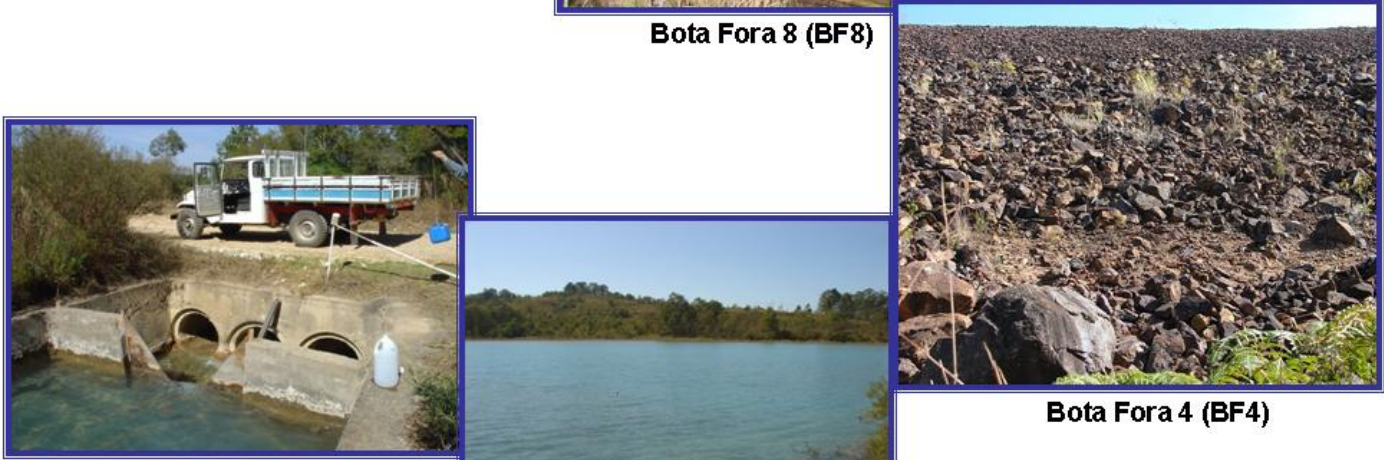

Ponto 41: saída do efluente tratado Lançado na Represa das Antas

Bacia de Decantação (BD)

Fonte: Indústrias Nucleares do Brasil - INB (2007), LIMA (2007) e RONQUI (2008) 
ANEXO C

\section{FÓRMULAS UTILIZADAS PARA A ESTIMATIVA DE BIOVOLUME}

\section{Forma Geométrica}

Fórmula do volume $\left.\left(\mu^{3}\right)^{3}\right)$

\begin{tabular}{lc} 
Cilindro & $V=\pi \cdot \mathbf{r}^{2} \cdot \mathbf{c}$ \\
\hline Elipsóide & $V=\frac{\pi \cdot \mathbf{1} \cdot \mathbf{c} \cdot \mathrm{e}}{6}$ \\
\hline Esfera & $V=\frac{\pi \cdot \mathrm{d}^{3}}{6}$
\end{tabular}

Tronco de Cone $\quad \mathrm{V}=\frac{\pi \cdot \mathbf{h}}{3}\left(\mathbf{r}_{1}^{2}+\mathbf{r}_{1} \cdot \mathbf{r}_{2}+\mathbf{r}_{2}^{2}\right)$

Prisma de Base Triangular $\quad \mathrm{V}=\frac{\mathbf{h . l} . \mathbf{e}}{2}$

Cone

$$
V=\frac{\pi \cdot r^{2} \cdot c}{3}
$$

\begin{tabular}{lc} 
Semi-Esfera & $V=1 / 2 \frac{\pi \cdot d^{3}}{6}$ \\
\hline $\begin{array}{l}\text { Elipsóide Rotacional } \\
\text { (WEISSE, 1997) }\end{array}$ & $V=W^{2} \cdot L \cdot \pi / 6$
\end{tabular}

$\mathrm{c}=$ comprimento d = diâmetro $\mathrm{e}=$ espessura h = altura I = largura $\mathbf{r}=$ raio, $\mathbf{r}_{1}=$ raio maior $W=$ largura $r_{7}=$ raio menor $\mathrm{L}$ = comprimento 


\section{ANEXO D}

\section{1 - Coloração de Membrana Nuclepore}

Dissolveram-se 0,2 g de Preto Sudão (Sudan Black em $100 \mathrm{rnL}$ de ácido acético P.A. e filtrou-se em membrana Millipore $0,22 \mu \mathrm{m}$. A soluçào é mantida à temperatura ambiente.

Os filtros foram colocados em uma placa de Petri contendo a solução de Preto Sudão até $3 / 4$ de sua altura. Após 96 horas, os filtros foram lavados com água destilada e 'secos sobre papel filtro.

2 - Preparações para solução de Laranja de Acridina ("acridine orange")

Para preparar a solução do corante $(3,6$ - bis Dimetilamino - acridina $\mathrm{C}_{17} \mathrm{H}_{20} \mathrm{ClN}_{2}$ ) para o equivalente a $100 \mathrm{~mL}$ é necessário $0.1 \mathrm{~g}$ de laranja de acridina e $100 \mathrm{~mL}$ de água destilada.

Deixar em repouso por três dias antes do uso. 


\section{ANEXO E \\ Toxicidade de Metais Pesados}

(Fonte: Nascimento, 2003)

Há considerável dissenção a respeito da definição de metais pesados, e consequentemente, de quais elementos deveriam ser incluídos nesta categoria. Uma das definições mais comuns é a que considera metais pesados como sendo aqueles que possuem peso específico maior ou igual a $5 \mathrm{~g} . \mathrm{cm}^{-3}$. O grupo inclui metais das séries de transição e os grupos IIA, IIIB, IVB, VB e VIB da tabela periódica dos elementos químicos. Entretanto, o termo metal pesado é frequentemente aplicado onde há a conotação de toxicidade, e assim uma definição menos rígida do grupo normalmente usada no contexto ambiental, é aquela que inclui metais mais leves como alumínio e berílio, e metalóides como arsênio, selênio e antimônio (RUDD, 1987).

Os organismos aquáticos, sejam da coluna d'água ou do sedimento, requerem certos metais traços para manter o metabolismo normal. Quando presentes em excesso, metais essenciais como Co, $\mathrm{Cu}, \mathrm{Zn}$ e Se, podem exercer efeitos tóxicos; outros como $\mathrm{Hg}, \mathrm{Cd}$ e $\mathrm{Pb}$ não são requeridos no metabolismo e podem exercer efeito deletério mesmo quando biologicamente disponíveis em níveis baixos de concentração (CAMPBELL, 1988).

A toxicidade de um metal ou composto metálico pode ser definida como sua capacidade intrínseca de causar efeito deletério às espécies vivas, incluindo os efeitos potenciais carcinogênico, mutagênico e teratogênico. A toxicidade pode ser manifestada de forma crônica ou aguda, sendo esta última comumente avaliada em animais pelo uso de testes padrões como o $\mathrm{DL}_{50}$, que é a dose letal requerida para matar $50 \%$ da população dos organismos testes num período de tempo fixado. De grande interesse ambiental, com respeito aos metais pesados, são os efeitos de longo tempo de exposição com baixas concentrações do contaminante. Essa forma, toxicidade crônica, é difícil de avaliar sob condições de laboratório devido à longa duração requerida para os experimentos. Outro aspecto da toxicidade crônica, que pode não ser aparente de estudos de laboratório sobre grupos de organismos testes, inclui o modo no qual a toxicidade crônica pode reduzir a capacidade geral do organismo visto que ele torna-se 
vulnerável a outros fatores potencialmente letais tal como a infecção. Se não morrer pela exposição crônica ao metal, o organismo ainda pode sofrer efeitos subletais tal como a redução no sucesso reprodutivo.

O modo preliminar de ação pelo quais os metais pesados exercem toxicidade no homem e animais são pela reação com os átomos doadores de enxofre das proteínas, resultando mais comumente na desativação da proteína. Além disso, substituindo outros elementos essenciais como cálcio e magnésio, os metais pesados podem desestabilizar a estrutura das biomoléculas. No caso de ácidos nucléicos, uma combinação de reações pode levar a falha de replicação e resultar em efeitos genotóxicos e mutagênicos produzindo câncer e desordem genética hereditável (RUDD, 1987).

A seguir, descrevem-se resumidamente os principais efeitos tóxicos de alguns metais pesados abordados neste estudo (WHO, 1994; RUDD, 1987; NASCIMENTO, 2003, SUZUKI; BANFIELD, 1999) abordados neste estudo.

\section{Urânio}

O urânio ocorre na crosta terrestre em uma concentração média de $2,4 \mathrm{mg} \cdot \mathrm{kg}^{-}$ 1. A toxicidade do urânio é derivada de suas propriedades químicas e radioatividade. Esta última não é letal a microorganismos devido a longa meia vida do urânio ( $\mathrm{t}_{1 / 2}=4,5.10^{9}$ anos) e ao curto ciclo de vida dos microorganismos. As propriedades químicas do urânio causam efeitos tóxicos similares àqueles induzidos pelos metais pesados que incluem bloqueio de rotas biologicamente essenciais, deslocamento ou substituição de íons essenciais das biomoléculas, desnaturação e inativação de enzimas, etc. Por exemplo, o urânio é muitas vezes assimilado mais que certos metais tais como cobre, zinco e níquel que tem funções essenciais em algumas enzimas. $O$ urânio pode substituir esses metais e destruir a sua função enzimática (SUZUKI; BANFIELD, 1999).

\section{Zinco}

O zinco ocorre na crosta terrestre em uma concentração média de $70 \mathrm{mg} \cdot \mathrm{kg}^{-1}$. As principais aplicações do zinco são no revestimento de proteção do ferro e aço, e fabricação de ligas de latão. Valores típicos em água potável estão compreendidos entre 0,007 a 0,3 mg. $\mathrm{L}^{-1}$. Em condições aeróbias, Zn (II) é a espécie predominante para $\mathrm{pH}$ ácido; em condições anaeróbias, forma ZnS entre 
pH 1 a 14. O zinco é rapidamente complexado por ligantes orgânicos, principalmente na presença de compostos de nitrogênio e enxofre. Em plantas aquáticas, em áreas não poluídas, a concentração de zinco varia entre 5 a 35 $\mathrm{mg} \cdot \mathrm{kg}^{-1}$, base seca.

A principal via de exposição humana é a ingestão. A inalação é uma fonte insignificante para exposição não ocupacional. Ingestão superior a $72 \mathrm{~g}$ de Zn produz sintomas de febre, diarréia, vômitos e outras irritações gastrointestinais. Em exposição ocupacional os trabalhadores podem mostrar distúrbios gastrointestinais e disfunção do fígado. O zinco não é considerado carcinogênico.

\section{Fluoreto}

Em condições normais de temperatura e pressão, o flúor é um gás corrosivo de coloração amarelo-pálido, fortemente oxidante. É o elemento mais eletronegativo e o mais reativo dos metais, formando compostos com praticamente todos os demais elementos, incluindo os gases nobres xenônio e radônio. Em ausência de luz e baixas temperaturas reage explosivamente com o hidrogênio. Jatos de flúor no estado gasoso atacam o vidro, metais, água e outras substâncias, que reagem formando uma chama brilhante. O flúor sempre se encontra combinado na natureza e tem afinidade por muitos elementos, especialmente o silício, não podendo ser guardado em recipientes de vidro. Em solução aquosa de seus sais, o flúor apresenta-se normalmente na forma de íons fluoretos, $\mathrm{F}^{-}$. Outras formas são complexos de flúor como o $\left[\mathrm{FeF}_{4}\right]^{-}$, ou o $\mathrm{H}_{2} \mathrm{~F}^{+}$. Os fluoretos são compostos nas quais os íons fluoretos estão ligados a algum resto químico de carga positiva. O flúor é um elemento químico essencial para o ser humano, pois está presente em mamíferos na forma de fluoretos. E, embora sua essencialidade não tenha sido comprovada inequivocamente (WHO, 2008Guidelines Para Qualidade da água), trata-se de uma substância essencial, que deve ser utilizada com cautela, por ser muito reativa e tóxica. Quando em pequenas quantidades se acumula nos ossos e dentes dando-lhes uma maior resistência, (embora algum efeito benéfico sobre os ossos não tenha sido bem comprovado). São acrescentados fluoretos em médias quantidades nos cremes dentais (1000 ppm 1500 ppm), que não devem ser engolidos, e em baixa quantidade em águas de consumo para evitar o surgimento de cáries $(0,6$ ppm 1,0 ppm). Entretanto a fluoretação da Água potável é motivo de 
controvérsias entre muitos cientistas, políticos e ativistas, pois o Flúor é considerado medicamento pela Organização Mundial da Saúde (OMS), que endossa sua adição na água, leite ou sal como forma eficaz de combater a cárie. A intoxicação por Flúor é conhecida como Fluorose, e se manifesta com um aspecto quebradiço e cromaticamente disforme dos dentes (mosqueamento). Geralmente acontece quando há o consumo em grandes quantidades de águas naturalmente fluoretadas, por parte de crianças, e em alimentos processados com estas águas, é importante que com a fluoretação seja feito o combate a desnutrição, para que bem suplementada de cálcio e iodo a criança não sofra de má mineralização com cristais defeituosos de Fluorita $\left(\mathrm{CaF}_{2}\right)$ e problemas da tireóide. É importante também que a substância usada tenha boa procedência e como fim a saúde pública. A lista dos efeitos pode ser assim resumida; para o consumo de compostos do flúor.

- 1,5 mg/dia a 2,5 mg/dia - Redução da cárie em até $70 \%$ com 20\%-40\% de fluorose, sem nenhum efeito tóxico considerável,

- 6,0 mg/dia - Anulação de boa parte do efeito benéfico, com presença de problemas ósseos e neurológicos em algumas crianças mal-nutridas e fluorose leve,

- 10,0 mg/dia a 20 mg/dia- Quantidade tóxica. Essa porção pode levar a moléstias ósseas como fluorose esquelética, artrite e fraturas de stress, associadas a distúrbios de aprendizagem em infantes. Está ligada a problemas relatados por pessoas vivendo próximo a fábricas de cerâmica e fertilizantes e consumidores de águas insalubres no Nordeste brasileiro. A água com mais de 1,5ppm deve ser tratada com adsorção, floculação, destilação ou osmose reversa.

- 200 mg - Nesta dosagem, relato de casos onde houve a morte por intoxicação de crianças mais sensíveis. Causando grande mau-estar gástrico devido a formação do ácido fluorídrico no estômago e consequente ferida na mucosa gástrica.

- 500 mg - 2 g - Com 500 mg, em um consumo único, causa parada cardíaca e morte em crianças e com doses a partir de $2 \mathrm{~g}$, de fluoreto de sódio, pode matar um adulto. Lavagem gástrica e consumo de água de cal $(\mathrm{Ca}(\mathrm{OH}) 2)$, hidróxido de magnésio, ou leite podem diminuir a absorção da substância por parte do organismo. É fundamental que o paciente seja levado a um hospital para tratamento. 


\section{Manganês}

É o terceiro metal mais abundante na crosta terrestre, atrás do alumínio e ferro e encontra-se amplamente distribuído. Situa-se no grupo 7 ( 7B ) da classificação periódica dos elementos. Sendo utilizado em ligas principalmente de aço e, também, para a produção de pilhas. O manganês é um elemento que ocorre principalmente sob a forma de $\mathrm{Mn}^{2+}$, podendo também ocorrer como $\mathrm{Mn}^{3+}$, é considerado essencial para a vida animal e vegetal, contudo, teores elevados conferem à água um odor e sabor desagradáveis. Ao oxidar-se, o manganês forma manchas de cor negra e favorece o crescimento de determinadas bactérias. Seu papel biológico como um elemento químico essencial para todas as formas de vida, nas quais tem funções tanto estruturais quanto enzimáticas. A química biológica do manganês está intimamente associada à química do oxigênio, em seus vários estados de oxidação. Nesse contexto, o manganês desempenha papel fundamental nos processos fotossintéticos de produçao de $\mathrm{O}_{2}$ (composto tetranuclear de $\mathrm{Mn}$ no fotossistema II), na degradação oxidativa de lignina (via as Mn-ligninases), em diversas reações de hidrólise e nos processos de proteção contra estresse oxidativo. Entre essas enzimas de proteção, destacam-se a superóxido dismutase de manganês (Mn-SOD), que catalisa o disproporcionamento de superóxidos, $\mathrm{O}_{2}^{-}$, e a Mn-catalase, que catalisa $\mathrm{O}$ disproporcionamento do peróxido de hidrogênio, $\mathrm{H}_{2} \mathrm{O}_{2}$. $\mathrm{Na}$ concavanila $\mathrm{A}$ (da família das lectinas), o manganês tem um papel estrutural. Em humanos, 0 manganês é absorvido no intestino delgado, acabando a maior parte no fígado, de onde se dirige para as diferentes partes do organismo. Sua carência nos humanos pode causar: perda de peso, fragilidade óssea, dermatite, degeneração do ovário ou testículos e náuseas. Seu excesso (em nível de nutriente) nos humanos pode causar: anorexia, alucinações, dificuldade de memorização, insônia e dores musculares. O manganês em excesso é tóxico. Exposições prolongadas a compostos de manganês, de forma inalada ou oral, podem provocar efeitos adversos no sistema nervoso, respiratório e outros.

Em água naturais, os seus teores são geralmente inferiores a 0,2 mg/L. 


\section{Tório}

O tório é um metal natural, sendo radioativo. Quando puro, o tório é um metal branco prateado que mantém o seu brilho por diversos meses. Entretanto, em presença do ar escurece lentamente tornando-se cinza ou, eventualmente, preto. O óxido de tório $\left(\mathrm{ThO}_{2}\right)$, também chamado de "tória", apresenta um dos pontos de ebulição mais elevados $\left(3300^{\circ} \mathrm{C}\right)$ de todos os óxidos. Quando aquecido no ar, o metal de tório inflama-se e queima produzindo uma luz branca brilhante.

O tório é encontrado em quantidades pequenas na maioria das rochas e solos, onde é aproximadamente três vezes mais abundante do que o urânio , e é aproximadamente tão comum quanto o chumbo. O solo contém geralmente uma média de 6 ppm de tório, ocorrendo em diversos minerais, sendo o mais comum o mineral de terra rara de tório-fosfato (como as de Catalão-Ouvidor em Goiás), monazita, que contém até $12 \%$ de óxido de tório. Há depósitos substanciais em vários paises, sendo que as maiores fontes mundiais de tório são encontrados nos Estados Unidos, Madagascar, Índia, Sri Lanka e Austrália.

Suas aplicação consistem como elemento de liga para aumentar a resistência mecânica e a resistência a elevadas temperaturas do magnésio; é usado para revestir fios de tungstênio usados em equipamentos eletrônicos; utilizado em eletrodos para soldas cerâmicas de alta resistência ao calor. O óxido de tório é usado para controlar o tamanho das partículas de tungstênio usados em lâmpadas elétricas. Datação de Urânio, sendo utilizado para datar hominídios fósseis; como material para produzir combustível nuclear; o tório-232 bombardeado com nêutrons produz o fissionável isótopo U-233.

O tório se desintegra com a produção eventual de "thoron", um isótopo do radônio (220-Rn). O gás de radônio apresenta radiação perigosa. Consequentemente, uma ventilação boa das áreas onde o tório é armazenado ou manuseado é essencial.

A exposição ao tório contido no ar pode conduzir a um aumento do risco de contrair câncer dos pulmões, pâncreas e sangue. Este elemento não tem nenhum papel biológico conhecido. 